\title{
DEVELOPMENT OF ENERGY BALANCES FOR THE STATE OF CALIFORNIA
}

Prepared For:

California Energy Commission

Public Interest Energy Research Program

Prepared By:

Lawrence Berkeley National Laboratory

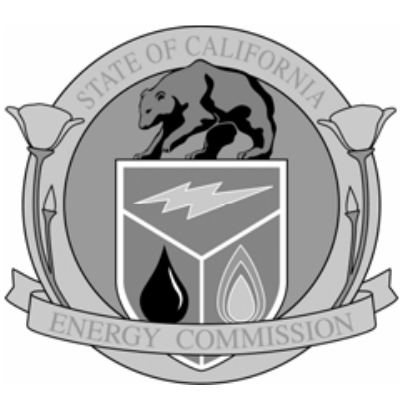

Arnold Schwarzenegger Governor

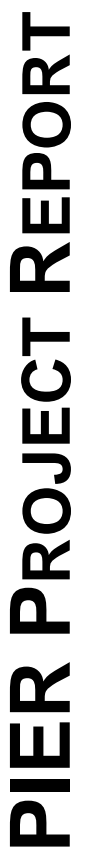




\section{California Climate Change Center Report Series Number 2005-017}

\section{Prepared By:}

Energy Analysis Department

Environmental Energy Technologies Division

Lawrence Berkeley National Laboratory

Berkeley, California

Scott Murtishaw

Lynn Price

Stephane de la Rue du Can

Eric Masanet

Ernst Worrell

Jayant Sathaye

Contract No. 500-02-004

Work Authorization MR-006

Prepared For:

California Energy Commission

Public Interest Energy Research (PIER) Program

Guido Franco,

Contract Manager

Kelly Birkinshaw,

Program Area Team Lead

Energy-Related Environmental Research

Ron Kukulka,

Acting Deputy Director

ENERGY RESEARCH AND DEVELOPMENT

DIVISION

Robert L. Therkelsen

Executive Director

\section{DISCLAIMER}

This report was prepared as the result of work sponsored by the California Energy Commission. It does not necessarily represent the views of the Energy Commission, its employees or the State of California. The Energy Commission, the State of California, its employees, contractors and subcontractors make no warrant, express or implied, and assume no legal liability for the information in this report; nor does any party represent that the uses of this information will not infringe upon privately owned rights. This report has not been approved or disapproved by the California Energy Commission nor has the California Energy Commission passed upon the accuracy or adequacy of the information in this report. 


\section{Acknowledgements}

This work was supported by the California Energy Commission through the U.S. Department of Energy. We would like to thank a number of people for their assistance in providing and interpreting data, including Bob Adler, Chanelle Wirner, Fred Freme, Tammy Heppner, Julia Hutchins, Robert Latta, Perry Lindstrom, Stephanie Battles, Robert Schnapp, and Dan Walzer (U.S. Energy Information Administration); Andrea Gough, Gerry Bemis, Leigh Stamets, Brian Helmowski, Adam Pan, Gordon Schremp, and Bill Wood (California Energy Commission); Gina Kaiper and Ray Smith (Lawrence Livermore National Laboratory); Gregg Morris (Green Power Institute); Jim Guthrie (California Air Resources Board); Becky BostonSharron (Asphalt Institute); and Ron Calvert (California ISO). We extend our gratitude to Barbara Adams at Berkeley Lab for constructing the energy balance flow chart (Figure 1). We would also like to especially thank Guido Franco of the California Energy Commission for his extremely helpful guidance throughout this project.

Please cite this report as follows:

Murtishaw, S., L. Price, S. de la Rue du Can, E. Masanet, E. Worrell, J. Sathaye. 2005.

Development of Energy Balances for the State of California. California Energy Commission, PIER Energy-Related Environmental Research. CEC-500-2005-068. 


\section{Preface}

The Public Interest Energy Research (PIER) Program supports public interest energy research and development that will help improve the quality of life in California by bringing environmentally safe, affordable, and reliable energy services and products to the marketplace.

The PIER Program, managed by the California Energy Commission (Energy Commission), annually awards up to $\$ 62$ million to conduct the most promising public interest energy research by partnering with Research, Development, and Demonstration (RD\&D) organizations, including individuals, businesses, utilities, and public or private research institutions.

PIER funding efforts are focused on the following RD\&D program areas:

- Buildings End-Use Energy Efficiency

- Energy Innovations Small Grant Program

- Energy-Related Environmental Research

- Energy Systems Integration Environmentally Preferred Advanced Generation

- Industrial/Agricultural/Water End-Use Energy Efficiency

- Renewable Energy Technologies

The California Climate Change Center (CCCC) is sponsored by the PIER program and coordinated by its Energy-Related Environmental Research area. The Center is managed by the California Energy Commission, Scripps Institution of Oceanography at the University of California at San Diego, and the University of California at Berkeley. The Scripps Institution of Oceanography conducts and administers research on climate change detection, analysis, and modeling; and the University of California at Berkeley conducts and administers research on economic analyses and policy issues. The Center also supports the Global Climate Change Grant Program, which offers competitive solicitations for climate research.

The California Climate Change Center Report Series details ongoing Center-sponsored research. As interim project results, these reports receive minimal editing, and the information contained in these reports may change; authors should be contacted for the most recent project results. By providing ready access to this timely research, the Center seeks to inform the public and expand dissemination of climate change information; thereby leveraging collaborative efforts and increasing the benefits of this research to California's citizens, environment, and economy.

The work described in this report was conducted under the Preliminary Economic Analyses of Climate Change Impacts and Adaption, and GHG Mitigation contract, contract number 500-02-004, Work Authorization MR-006, by the Lawrence Berkeley National Laboratory.

For more information on the PIER Program, please visit the Energy Commission's Web site www.energy.ca.gov/pier/ or contract the Energy Commission at (916) 654-4628. 


\section{Table of Contents}

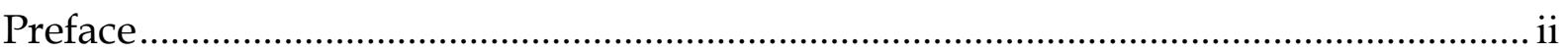

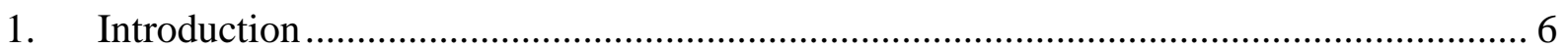

1.1 Background of the California Energy Balances Project .......................................... 6

1.2 Data Hierarchy: Primary, Alternative, Supplemental ................................................ 6

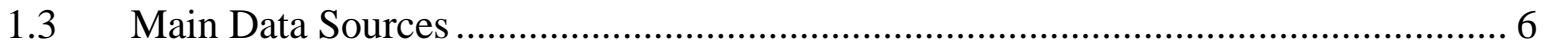

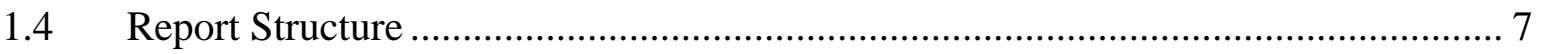

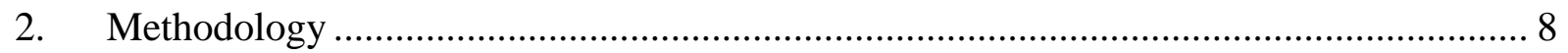

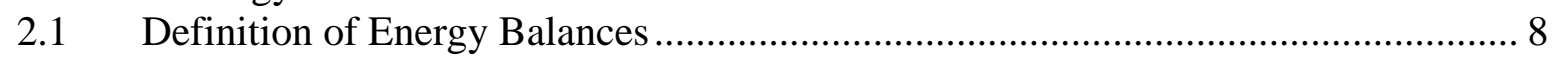

2.2 Overview of Energy Balance Dimensions ............................................................. 8

2.3 Energy Conversions ............................................................................................ 9

$2.4 \quad$ Greenhouse Gas Conversions ........................................................................ 10

3. California Energy and Electricity Balances - 2000...................................................... 11

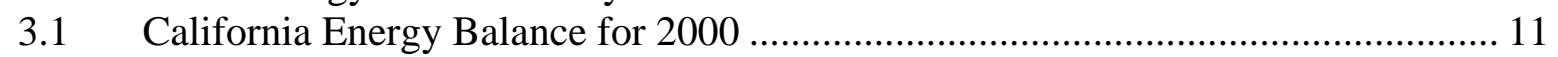

3.2 California Electricity Balance for 2000 ..................................................................... 15

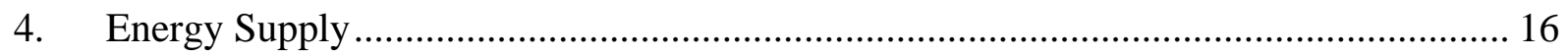

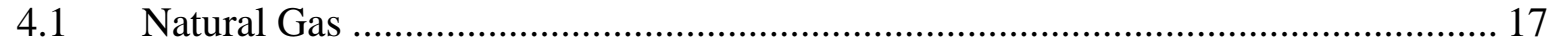

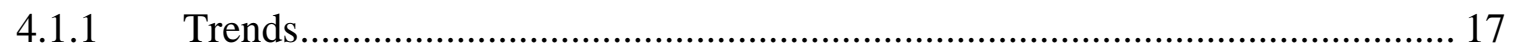

4.1.2 Data Sources and Data Issues .................................................................. 18

4.2 Crude Oil and Petroleum Products..................................................................... 18

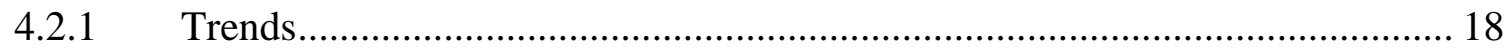

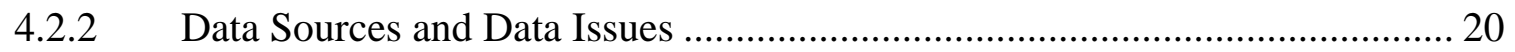

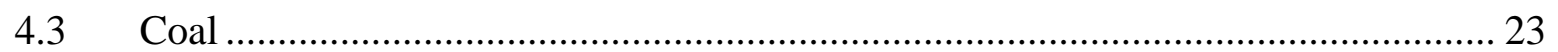

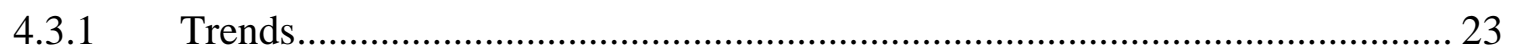

4.3.2 Data Sources and Data Issues ......................................................................... 24

4.4 Electricity Imports and Non-Fossil Electricity Generation Inputs............................. 24

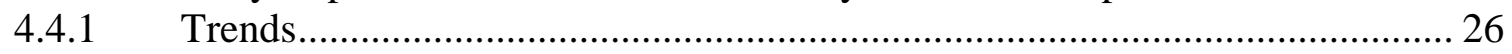

4.4.2 Data Sources and Data Issues ................................................................... 27

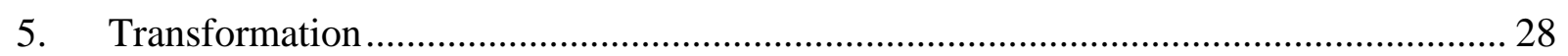

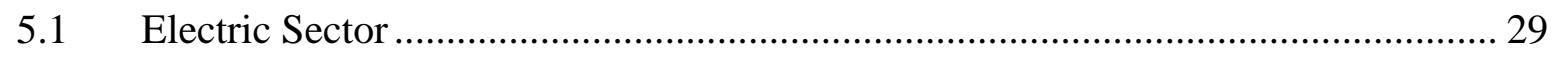

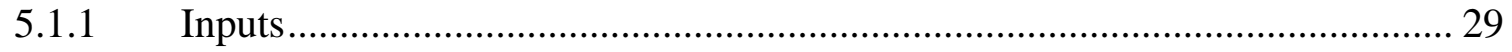

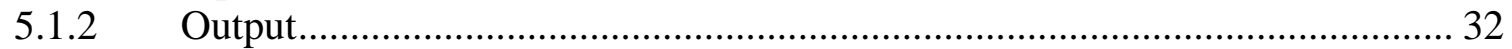

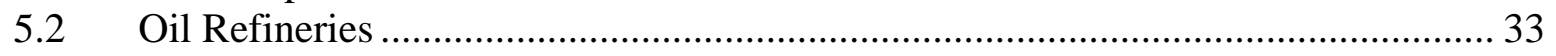

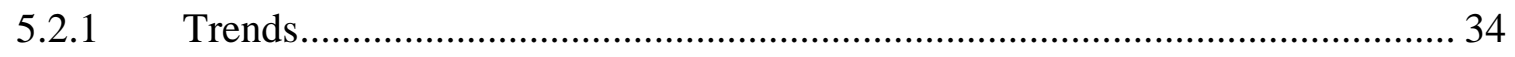

5.2.2 Data Sources and Data Issues ..................................................................... 34

5.3 Energy Sector: Own Use ........................................................................................ 35

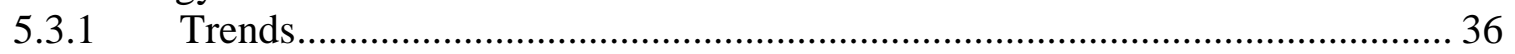

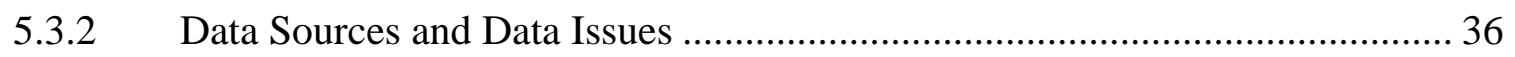

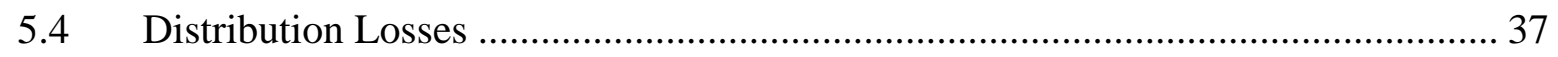

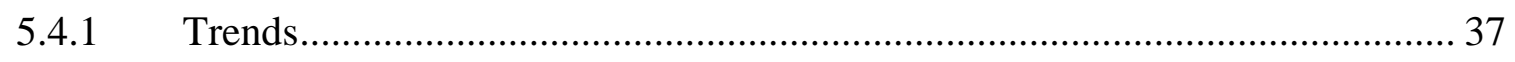

5.4.2 Data Sources and Data Issues ....................................................................... 37

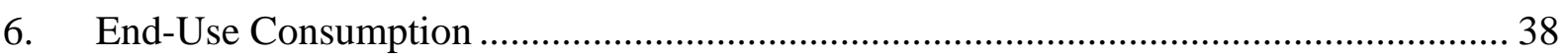


6.1 Energy End-Use Consumption Sectors.........................................................38

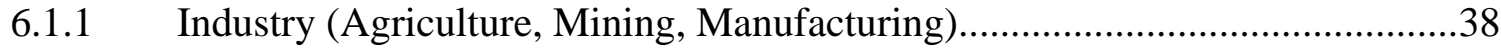

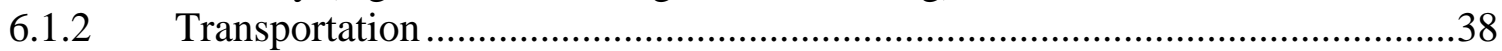

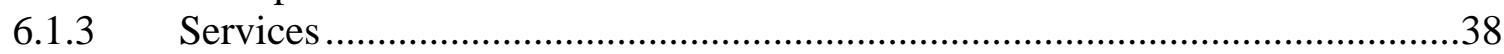

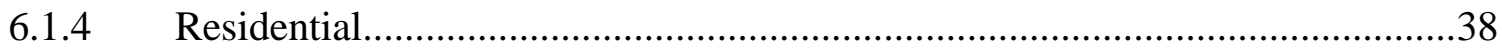

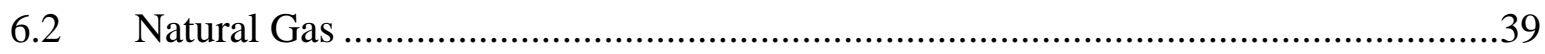

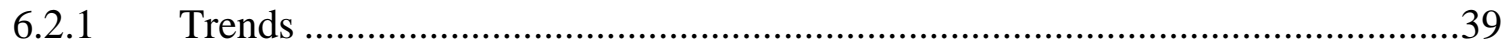

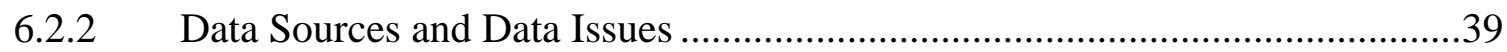

Petroleum Products .......................................................................................4

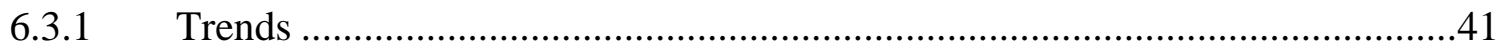

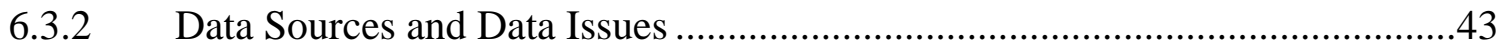

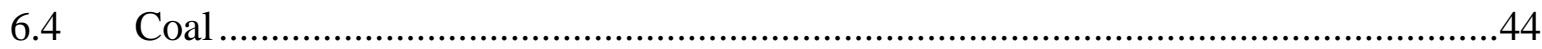

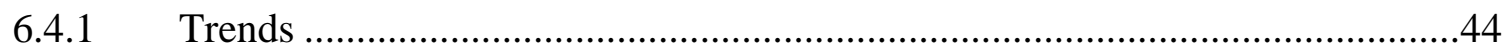

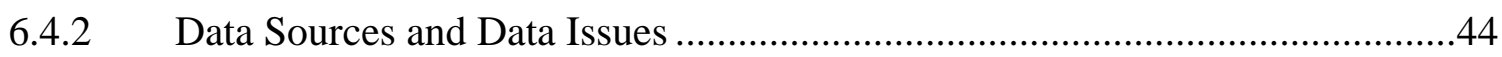

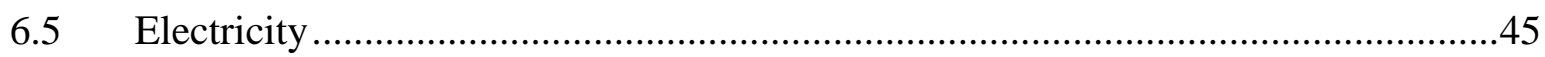

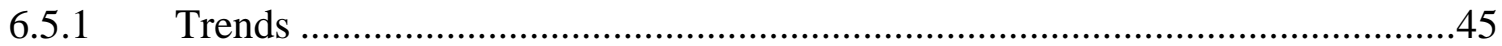

6.5.2 Data Sources and Data Issues .............................................................45

7. Total Consumption and Statistical Differences ......................................................46

8. Carbon Dioxide Emissions from Fuel Consumption ...................................................47

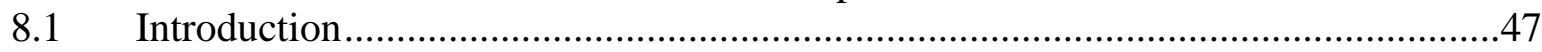

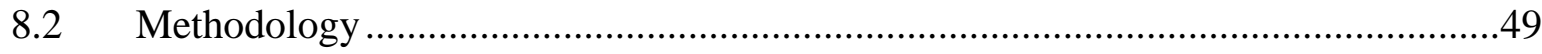

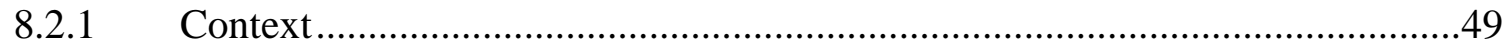

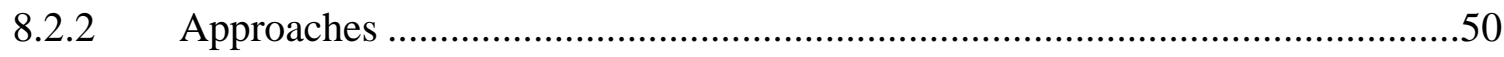

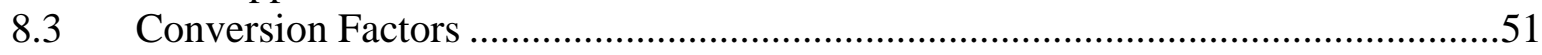

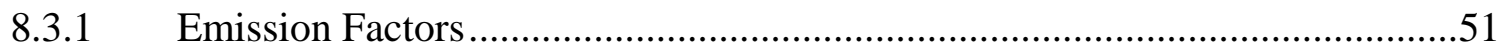

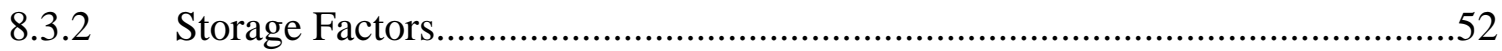

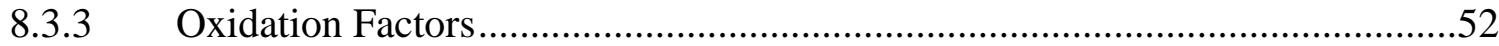

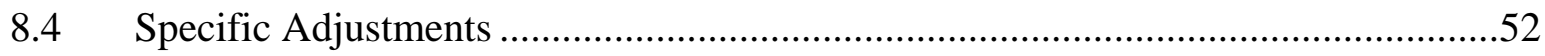

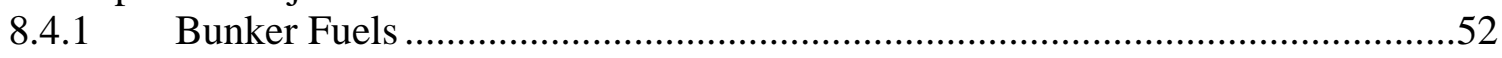

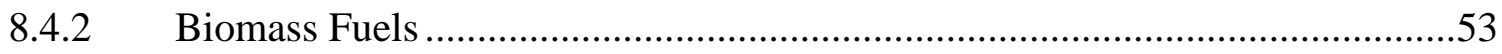

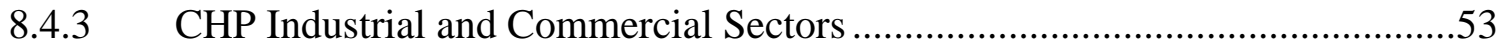

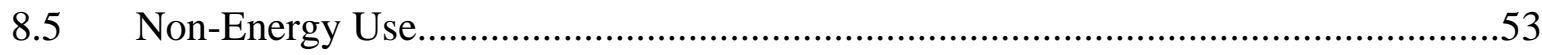

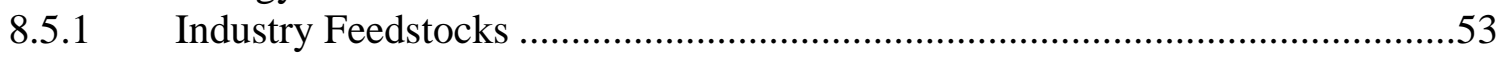

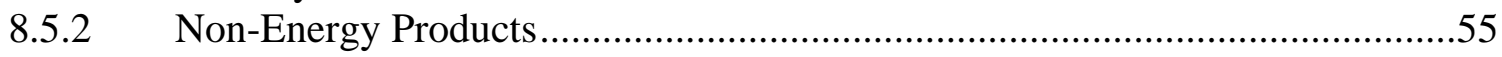

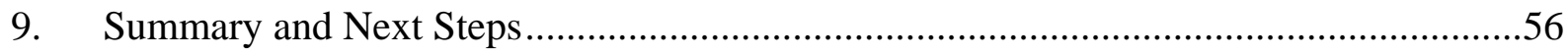

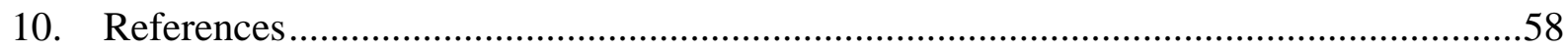

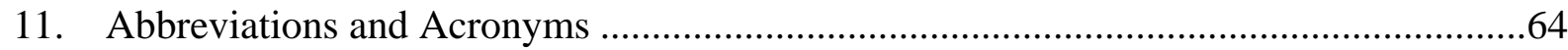




\section{List of Figures}

Figure 1. California energy flows in 2000, trillion Btu........................................................ 14

Figure 2. Sources of California crude oil, 1982 to 2001 ..................................................... 19

Figure 3. Sources of foreign crude oil imported to California, 2002 ...................................... 19

Figure 4. Electricity produced in California by type of primary energy input, 1990 to 2001 ..... 33

Figure 5. $\mathrm{CO}_{2}$ Emissions fuel combustion in California by fuel and sector in 2000, $\mathrm{Mt} \mathrm{CO}_{2} \ldots . .48$

\section{List of Tables}

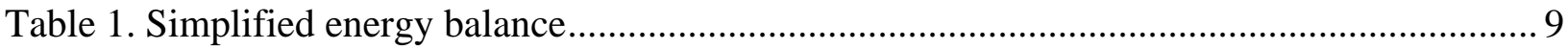

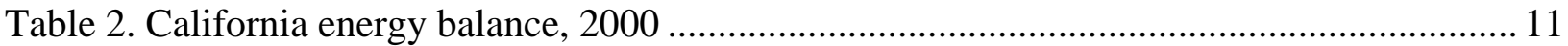

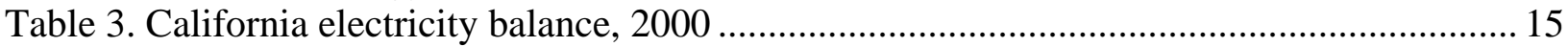

Table 4. California supply of natural gas, 1990 to 2001 ........................................................... 17

Table 5. California supply of crude oil, 1990 to 2001 ............................................................. 18

Table 6. Imports and exports of petroleum product additives and feedstocks, 1996 to 2001...... 20

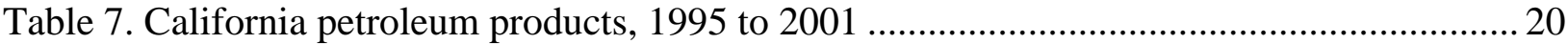

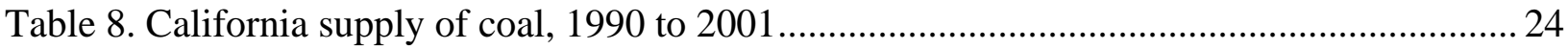

Table 9. Sources of coal imported to California, 1990 to 2001 .................................................. 24

Table 10. Sources of electricity imported to California, 1990 to 2001 (GWh) ......................... 26

Table 11. Non-fossil fuel inputs to electricity generation (trillion Btu) ................................... 27

Table 12. Transformation phase for the California energy balance for 2000 (TBtu) .................. 28

Table 13. Energy inputs to the electricity sector: Petroleum products ................................... 30

Table 14. Energy inputs to the electricity sector: Natural gas ............................................... 30

Table 15. Energy inputs to the electricity sector: Coal .......................................................... 31

Table 16. Energy inputs to the electricity sector: Other.......................................................... 31

Table 17. Electricity produced in California by type of primary energy input, 1990 to 2001

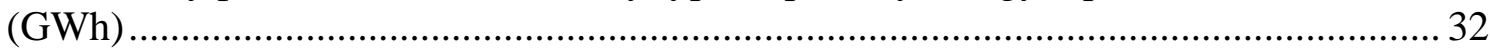

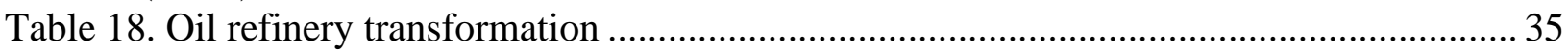

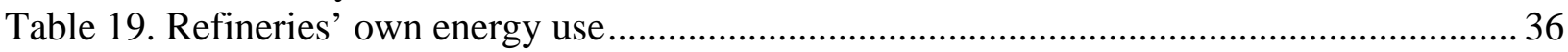

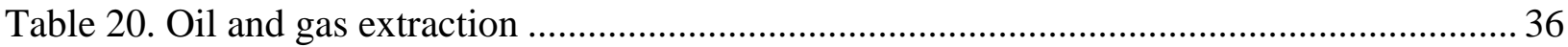

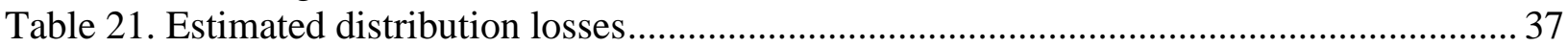

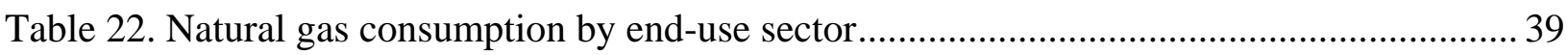

Table 23. Motor gasoline consumption by end-use sector................................................... 41

Table 24. Distillate fuel oil consumption by end-use sector .................................................... 41

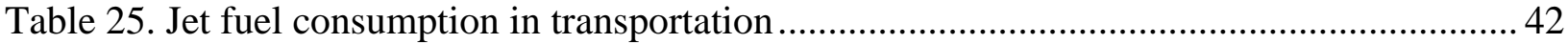

Table 26. Other petroleum products consumption by end-use sector ....................................... 42

Table 27. Consumption of coal by end-use sector ........................................................... 44

Table 28. Electricity consumption by end-use sector .......................................................... 45

Table 29. Statistical differences by energy source in trillion Btu .............................................. 46

Table 30. 2000 Carbon dioxide emissions from fuel combustion in California, million metric

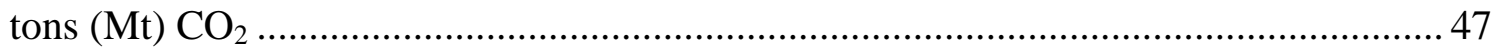

Table 31. Detailed $\mathrm{CO}_{2}$ emissions in the transport sector in 2000, $\mathrm{Mt}$ of $\mathrm{CO}_{2} \ldots \ldots \ldots \ldots \ldots \ldots \ldots \ldots . . . . . . . . . . .48$

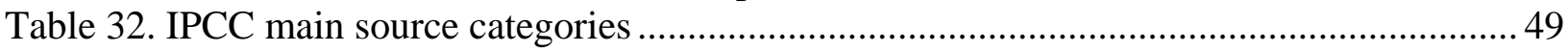

Table 33. Carbon content factors, storage factors and fraction of oxidation .............................. 51

Table 34. Non-energy use of fuel in 2000 (TBtu).............................................................. 53 


\begin{abstract}
Analysts assessing energy policies and energy modelers forecasting future trends need to have access to reliable and concise energy statistics. Lawrence Berkeley National Laboratory evaluated several sources of California energy data, primarily from the California Energy Commission and the U.S. Energy Information Administration, to develop the California Energy Balance Database (CALEB). This database manages highly disaggregated data on energy supply, transformation, and end-use consumption for each type of energy commodity from 1990 to the most recent year available (generally 2001) in the form of an energy balance, following the methodology used by the International Energy Agency. This report presents the data used for CALEB and provides information on how the various data sources were reconciled. CALEB offers the possibility of displaying all energy flows in numerous ways (e.g., physical units, Btus, petajoules, different levels of aggregation), facilitating comparisons among the different types of energy commodities and different end-use sectors. In addition to displaying energy data, CALEB can also be used to calculate state-level energy-related carbon dioxide emissions using the methodology of the Intergovernmental Panel on Climate Change.
\end{abstract}




\section{Executive Summary}

The California Energy Balances (CALEB) project is an effort by Lawrence Berkeley National Laboratory (Berkeley Lab) to provide a comprehensive set of data for energy production, transformation, and consumption for the State of California for the period 1990 to present. The California Energy Commission (Energy Commission) requested that these data distinguish among fuels and incorporate the maximum degree of sectoral and sub-sectoral disaggregation possible. The Energy Commission also requested that Berkeley Lab compile energy data from different sources, determine the quality of the data, and explain and resolve any data discrepancies. These data have been used to produce the CALEB database, a versatile database that allows users to explore California energy data in a variety of formats. This report documents the data collection effort as well as the resolution of data discrepancies for the energy production, transformation, and consumption data for the CALEB project. Most of the data used for CALEB were taken either from the Energy Commission or the U.S. Energy Information Administration (EIA).

Energy balance databases arrange data into three principal dimensions: (1) products, (2) flows, and (3) time. Products are simply the various energy sources. They consist of natural gas, crude oil and petroleum products, coal, electricity, and other minor energy sources. This report distinguishes between primary electricity from sources such as hydro, wind, and solar photovoltaic and secondary electricity produced from converted thermal energy. Flows refer to processes of supplying, transforming, and consuming energy. The transformation phase refers to the energy used to extract and process energy resources as well as the energy inputs themselves that are transformed into secondary sources (for example the crude oil that is refined into petroleum products). The consumption phase signifies all of the end uses of energy throughout the economy. Time denotes the calendar year or years of the energy data available. An energy balance per se consists of a balancing of supply, transformation, and consumption data in a given year.

Figure ES-1 depicts the energy balance data for 2000 as an energy flow chart. Reading from left to right, the figure shows all the inputs of primary (and imported secondary) energy into California's economy in 2000. These are summed by major fuel types in the middle of the figure: petroleum and associated products, natural gas, coal, and inputs to electricity generation. The right side shows how all of the fuels are allocated to the various end uses.

\section{Energy Supply}

The energy supply phase of an energy balance documents those flows of energy available to the economy prior to transformation and consumption. The energy supply flow includes indigenous energy production, imports, exports, international marine bunkers, and net stock withdrawals. 


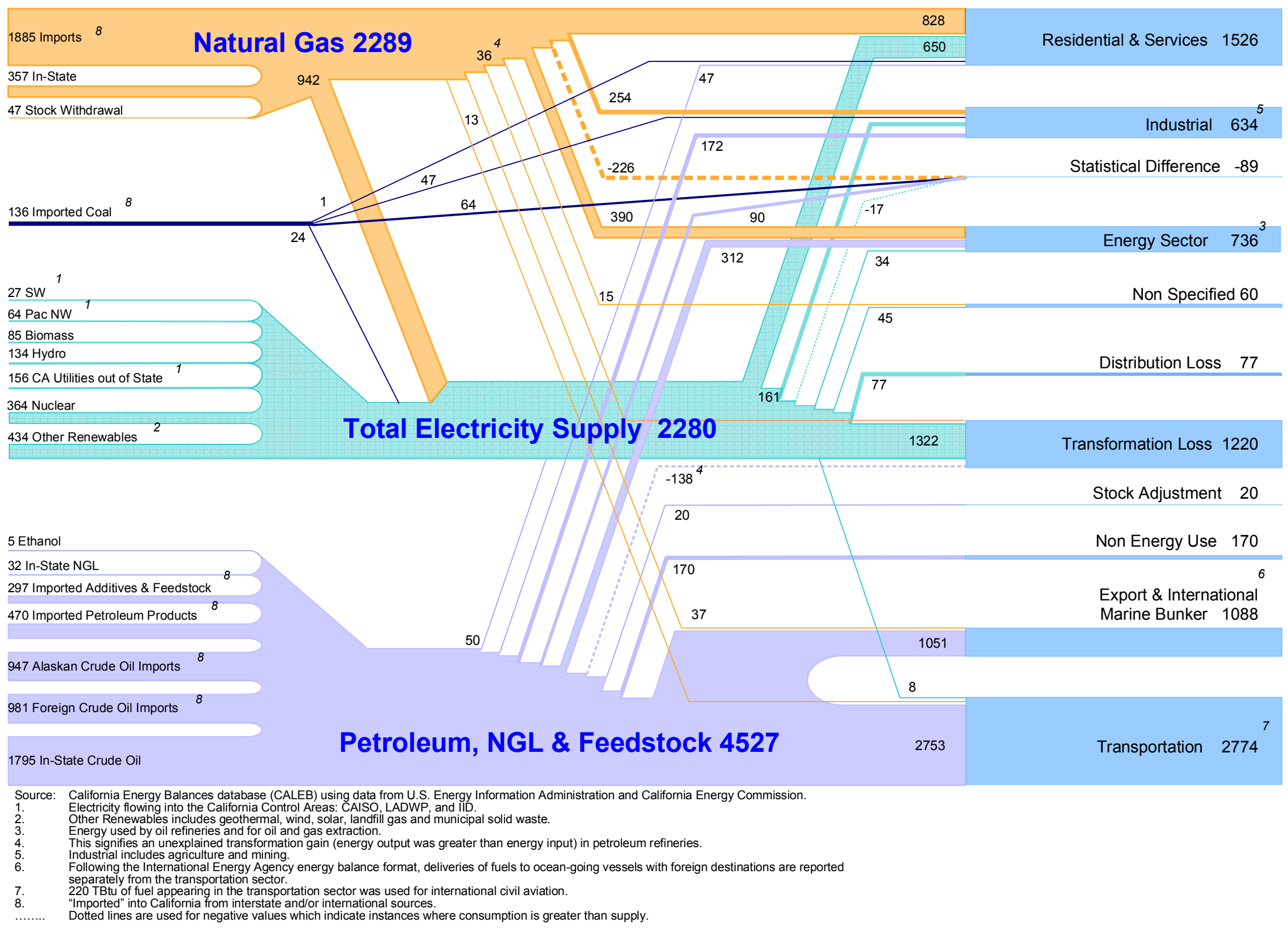

Figure ES1. California energy flows in 2000, trillion Btu 
Indigenous energy production accounts for the primary energy extracted from within the country (or state). This consists only of primary forms of energy such as natural gas, crude oil, coal, and production of primary electricity. The treatment of international bunker fuels (fuels used by airplanes and ocean-going vessels for transit to foreign destinations) presents a number of methodological and statistical challenges. For the purposes of constructing national greenhouse gas (GHG) inventories, the Intergovernmental Panel on Climate Change (IPCC) recommends that emissions from all international bunker fuels be excluded from national totals. In practice, deliveries of these fuels are not reported separately for domestic and international trips. The figures in the CALEB database have been adjusted to reflect the consumption of intrastate, interstate, and international travels. Deliveries of international marine bunker fuel are shown in energy balance tables as part of "Energy Supply"; whereas, total consumption of aviation fuels is shown in the "Transport" category and is not deducted from the energy supply. However, the share of aviation fuel used for international travel is reported as a separate item and should be deducted from consumption totals for purposes of calculating a GHG emission inventory. Net stock withdrawal indicates the net quantities of fuels taken from or added to stock over the course of the year.

Supply data for most energy sources are complete for the years 1990 to 2001. However, complete data for imports and exports of petroleum products are only available from 1996 to 2001.

Unless imported or exported, electricity per se does not appear in the "Energy Supply" portion of the energy balance. Rather, it is the inputs to electricity generation that are shown. An energy balance distinguishes primary energy from secondary energy. There are two different methods used to "back-calculate" the primary energy necessary to produce non-fossil fuel electricity: (1) the partial substitution method, and (2) the physical energy content method.

The partial substitution method calculates how much primary energy this production of electricity would require if it were generated by fossil fuels. The EIA uses this method in its Annual Energy Review. The second method-the physical energy content method-is used by the International Energy Agency (IEA) and was adopted for the CALEB database. Following this convention, the electricity produced is considered the primary form of energy for nonthermal energy sources (e.g., hydro, wind, solar, and wave power). Following the IEA convention, the electricity produced is considered the primary form of energy for non-thermal energy sources (e.g., hydro or wind), while heat is commonly accepted as the primary form of energy in the production of electricity from non-fossil thermal energy sources (e.g., nuclear fission or geothermal).

\section{Energy Transformation}

The transformation phase of an energy balance accounts for two distinct aspects of energy provision: (1) energy inputs that are ultimately converted to secondary sources, and (2) the energy used for the extraction and processing of energy resources (e.g., coal mining, oil and gas extraction, process energy use at refineries). The electricity sector is disaggregated into five types of energy providers, following the EIA classifications currently used in the Electric Power Annual publications and data sets. These consist of: (1) utilities; (2) independent power producers (IPPs); (3) combined heat and power (CHP), electric power sector; (4) CHP, 
industrial sector; and (5) CHP, commercial sector. Combined heat and power facilities are required to report only the fuel used to generate electricity that is either consumed onsite or sold. The quantity of fuel used to generate heat or steam for industrial/commercial purposes is not included, and is therefore shown as part of end use consumption (included either in manufacturing or services).

The consumption of energy needed to operate refineries or power plants is provided under the "Energy Sector: Own Use" category, as is the energy required to extract energy resources. This may consist of purchased electricity or natural gas or energy recovered on site. For example, a significant portion of the crude oil that enters a refinery is ultimately used for process energy. This category also includes the energy used for oil and natural gas extraction and energy used for coal mining. In California, major transformation sector consumers of energy include natural gas power plants, oil refineries, and the energy used for oil and gas extraction.

Electricity distribution losses occur in the transmission and distribution of electricity to consumers. Because actual data on losses are difficult to obtain, losses are currently estimated by induction, using an assumption of $8 \%$ losses of electricity delivered to the grid.

\section{Energy Consumption}

For the purpose of the CALEB database, energy consumption data have been categorized into four principal end-use sectors: (1) industry, (2) transportation, (3) services, and (4) residences. Consumption of petroleum products by the end-use sectors remained relatively stable overall during the period 1990 to 2000, but among the individual sectors, industry's use of petroleum products decreased significantly, while use in the transportation sector grew. Use of motor gasoline increased substantially over this period, with consumption in 2000 more than $10 \%$ higher than in 1990. Industry's consumption of other petroleum products dropped sharply after 1990, largely due to a corresponding drop in "other petroleum products" as reported by the EIA, as well as drops in the reported use of liquid petroleum gas (LPG) and residual fuel oil. Coal is used for some electricity generation at CHP facilities, but otherwise its use is limited mostly to the cement industry.

\section{Conclusions}

This report presents the findings from the first stage of the CALEB data project. Overall, the total statistical difference between supply and consumption for 2000 was a little less than $1 \%$. Unfortunately, this encouragingly low difference in the totals does not apply to all of the individual fuels or all of the years covered by the database. The statistical differences for coal, natural gas, and certain petroleum products remain quite large.

With respect to transformation of petroleum products, Berkeley Lab and Energy Commission staff need to collect and analyze petroleum product data for years other than 1995 to 2001 in order to complete the CALEB flows back to 1990. Additional effort is needed to improve the petroleum product balance even for 1995 to 2001, due to the complexity of refinery operations and petroleum product flows. 
Three aspects of petroleum product consumption also need to be further developed to improve the balance. First, detailed subsector-level data are not maintained due to the decentralized nature of petroleum product distribution. Data are only reported at highly aggregated, sectoral levels by sources such as the EIA's State Energy Data System. However, any attempt to allocate consumption to more detailed subsectors would require significant analysis and would ultimately rest on a number of assumptions. Second, improved estimates of bunker fuels for interstate and international shipping and aviation are needed. Currently, data on sales of jet fuel and marine bunker fuels are not disaggregated by vehicle destination. Berkeley Lab has conducted an initial analysis of maritime shipping and flight records for a few recent years to allocate international bunker fuel consumption for all years in CALEB. Finally, more data are also needed to better estimate the use of petroleum products, natural gas, and NGLs for feedstocks.

The electricity sector has also presented several analytic hurdles. Data on actual power flows into and out of the state are not publicly available; hence, Energy Commission figures on estimated net imports were used. A future research task entails the examination of Federal Energy Regulatory Commission (FERC) 714 forms to quantify bulk exchanges between power control areas, in order to more precisely estimate imports and exports. Two other forms, the FERC 1 and EIA 714, provide considerable detail on power purchases by supplier. Despite the level of detail provided by these two data sources, there are two main obstacles to using them to accurately account for all electricity imports and exports for the State of California. The first is that from 1998 to 2000 the investor-owned utilities (IOUs) began to purchase large shares of their power from the California Power Exchange. The sources of power that supplied the Power Exchange are not publicly disclosed. Second, California utilities purchase some power from energy marketers and California Department of Water Resources (DWR), and these organizations do not disclose the sources of the power they sell on either the FERC 1 or EIA 412.

An additional task for completing the consumption data for natural gas entails estimating the fuel consumed to produce useful heat from CHP units. This has been done for the years 1998 through 2000 for the current version of CALEB, but missing data complicate estimations for other years.

In the future, inclusion of economic activity data (such as population, value added, passengermiles traveled, and service sector floor space) would enable CALEB to produce indicators of energy intensity (energy consumed per unit of activity) for various end-use sectors. With sufficient data, a decomposition of structural and intensity trends driving energy use in California may be possible. 


\section{Introduction}

\subsection{Background of the California Energy Balances Project}

The California Energy Balances (CALEB) project is an effort by Lawrence Berkeley National Laboratory (Berkeley Lab) to provide a comprehensive set of data for energy production, transformation, and consumption for the State of California for the period 1990 to present. The California Energy Commission (Energy Commission) requested that these data distinguish among fuels and incorporate the maximum degree of sectoral and sub-sectoral disaggregation possible. The Energy Commission also requested that Berkeley Lab compile energy data from different sources, determine the quality of the data, and explain and resolve any data discrepancies. These data have been used to produce the CALEB database, a versatile database that allows users to explore California energy data in a variety of formats. This report documents the data collection effort as well as the resolution of data discrepancies for the energy production, transformation, and consumption data for the CALEB project.

\subsection{Data Hierarchy: Primary, Alternative, Supplemental}

Data fall into three basic types with regard to their certainty and completeness: (1) primary data, (2) alternate data, and (3) supplemental data. Primary data sources are those chosen as definitive for use in the CALEB database. Primary data are the only data used for calculating the balance. Alternate data sources are those that provide parallel data to the primary data series, but that Berkeley Lab has judged as less reliable. In cases where reliable state and federal data were available for the same series, state data were favored, because Energy Commission staff can more easily resolve any problems or uncertainties with these data. Supplemental data provide a greater degree of disaggregation, but are incomplete subsets of a larger category or are based on estimates that are less reliable than more aggregate data. In future versions of the CALEB database, supplemental data may also be included for data on "activity" (i.e., drivers of energy consumption such as population, vehicle-miles traveled, value added, and floor area) and other factors affecting energy use (e.g., average heating and cooling degree-days).

\subsection{Main Data Sources}

The principal data sources used in this project are the U.S. Energy Information Administration (EIA), the Energy Commission, and the California Department of Conservation. Data from the EIA cover overall state-level energy supply (U.S. EIA, 2004a) and energy consumption by fuel source and by end-use sector for 1960-2000 in the State Energy Data System 2001 (SEDS) report (U.S. EIA, 2003a), as well as detailed data on the supply of major energy sources such as petroleum, natural gas, coal, renewable energy, and electric power generation (U.S. EIA, 2003b; U.S. EIA, 2003c; U.S. EIA, 2004b; U.S. EIA, 2004c; U.S. EIA, various years). Data from the Energy Commission cover electricity and natural gas consumption, natural gas supply, crude oil supply, and electricity generation (CEC, 2003a; CEC 2003b; CEC, 2003c; CEC, 2004a; CEC, 2004b; CEC, 2004c; CEC, 2004d; CEC, 2004e; CEC, 2004f). The California Department of Conservation provides data on extraction, production, and production losses data for natural gas, natural gas liquids, and petroleum production to the Energy Commission-as well as in its annual reports (California Department of Conservation, 
various years). Supplemental data for biomass were obtained from Gregg Morris of the Green Power Institute (Morris, 2002; Morris, 2004), data for energy consumption in the cement industry were obtained from the U.S. Geological Survey (van Oss, 2004), and alternative data on sales of gasoline and diesel were provided by the Energy Commission, compiled from California Board of Equalization data (California BOE, 2003).

The CALEB database currently contains data for many series up to 2003. However, due to incompleteness of data for more recent years, most tables in this report only show figures up to 2000 or 2001.

Previous studies of energy use in California also provided valuable references for this project, including a detailed study of historical trends in energy efficiency (Schipper and McMahon, 1995) and a more general report on energy flows in California that attempts to balance energy throughputs in a manner similar to the CALEB balances (Kaiper, 2003).

\subsection{Report Structure}

This report begins in Section 2 with an overview of the methodology used to construct energy balances. Section 3 shows the results of an energy balance for California for the year 2000, and provides a more detailed balance for the electricity sector. Figures for California's energy supply from 1990 to the most recent year available are shown in Section 4, which is organized by energy type. In addition, Section 4 describes in detail the data sources used and issues that arose in reconciling various data sources. Sections 5 and 6 provide a comparable breakdown of the data used for the transformation and consumption phases of CALEB. Section 7 discusses the statistical differences that remain when total consumption is subtracted from total supply. Section 8 reviews the methods and data sources used for calculations of carbon dioxide $\left(\mathrm{CO}_{2}\right)$ emissions in CALEB. Sample estimates are shown for the year 2000. Section 9 concludes the report with a discussion of overall data issues and possible next steps for further enhancement and refinement of the CALEB database. 


\section{Methodology}

\subsection{Definition of Energy Balances}

Energy balances tabulate energy data in an attempt to account for the entire energy throughput in a nation's (or state's) economy. The International Energy Agency (IEA) has produced annual energy balances for 134 countries since the 1970s and has developed a detailed methodology for accounting for the energy flows in an economy (IEA, 2003a; IEA, 2003b). Berkeley Lab has largely relied on the conventions used by the IEA for its work in developing the CALEB database. Additionally, a United Nations report provided an extremely thorough review of the methodological issues surrounding the construction and presentation of energy balances (United Nations, 1982). That document was particularly helpful for elucidating methodological issues surrounding energy transformation and the calculation of primary energy inputs to power generation from non-fossil fuels.

A semantic distinction that needs to be made is that in IEA parlance, data reported in physical units are referred to as "statistics"; whereas, data reported in energy units are referred to as "balances." This distinction is important, because physical units cannot be "balanced," since the units differ among fuels. This report discusses examples of both statistics (in physical units) and balances (in energy units).

\subsection{Overview of Energy Balance Dimensions}

Energy balance databases arrange data into three principal dimensions: (1) products, (2) flows, and (3) time.

Products are simply the various energy sources. They consist of natural gas, crude oil and petroleum products, coal, electricity, and other minor energy sources. This research distinguishes between primary electricity from sources such as hydro, wind, and solar photovoltaic and secondary electricity produced from converted thermal energy. This distinction prevents double counting of the energy in the fossil fuels (and other heat sources) that is converted to electrical energy.

Flows refer to processes of supplying, transforming, and consuming energy. These three broad categories of flows constitute the "phases" of energy within a balance. Generally, supply flows (such as indigenous production, import, export, and stock withdrawal) are listed at the top of the balance. The transformation phase refers to the energy used to extract and process energy resources, as well as the energy inputs themselves that are transformed into secondary sources (for example the crude oil that is refined into petroleum products). The consumption phase signifies all of the end uses of energy throughout the economy. A wide range of disaggregation is possible within this phase, depending on the level of detail available in the underlying data. These flows are commonly divided into at least four major subsectors: (1) industry, (2) transportation, (3) residential, and (4) services.

Time denotes the calendar year or years of the energy data available. An energy balance per se consists of a balancing of supply, transformation, and consumption data in a given year. 
Table 1 shows a simplified energy balance. The positive sign $(+)$ indicates where energy is produced or imported and the negative sign (-) indicates where energy is consumed or exported. Not all fuel types are used to produce each type of energy shown in the balance, and this is indicated by "N/A" for "not applicable." While an energy balance database allows a user to see a time series of flows for a given product (e.g., the supply, transformation, and consumption of natural gas over some range of years), the complex methodological issues stem from the need to balance all flows, across all products, for a single year.

In addition to the three principal dimensions, other dimensions can also be presented in an energy balance database. For example, the IEA's database contains data on several countries and regions. Although the CALEB database only covers a single region (California), it offers the possibility of displaying the data in various units. Data are entered in the CALEB database as physical quantities, but the resulting balances can be shown in physical quantities, energy units, or $\mathrm{CO}_{2}$ emissions equivalents.

Table 1. Simplified energy balance

\begin{tabular}{|l|c|c|c|c|c|c|}
\hline & $\begin{array}{c}\text { Natural } \\
\text { Gas }\end{array}$ & $\begin{array}{c}\text { Crude } \\
\text { Oil }\end{array}$ & $\begin{array}{c}\text { Other } \\
\text { Petroleum } \\
\text { Products }\end{array}$ & Coal & $\begin{array}{c}\text { Primary } \\
\text { Electricity }\end{array}$ & $\begin{array}{c}\text { Secondary } \\
\text { Electricity }\end{array}$ \\
\hline Energy Supply & & & & & & \\
\hline Production & + & + & N/A & + & + & N/A \\
\hline Import & + & + & + & + & + & + \\
\hline Export & - & - & - & - & - & - \\
\hline Bunker Fuels & N/A & N/A & - & N/A & N/A & N/A \\
\hline Net Stock Withdrawals & $+/-$ & $+/-$ & $+/-$ & $+/-$ & N/A & N/A \\
\hline Transformation & & & & & & \\
\hline Electric Plants & - & N/A & - & - & N/A & + \\
\hline Oil Refineries & - & - & + & N/A & N/A & - \\
\hline End Use Consumption & & & & & & \\
\hline Industry & - & - & - & - & - & - \\
\hline Transport & - & - & - & - & - & - \\
\hline Residential Buildings & - & - & - & - & - & - \\
\hline Commercial Buildings & - & - & - & - & - & - \\
\hline Electricity Output (GWh) & + & + & + & + & + & + \\
\hline
\end{tabular}

\subsection{Energy Conversions}

Energy balances require that data be displayed in a common energy unit to permit comparison and balancing between flows and products. However, data are first collected in physical units, such as volume and mass. Conversion from physical units to energy units is determined by the quality of a product and can vary between regions, over time, and by uses. SEDS provides detailed annual conversion factors for California for natural gas and coal and distinguishes between their heating value, depending upon whether the fuel is used in the electricity sector, the industry sector (only for coal), or in other sectors (U.S. EIA, 2003a). Petroleum products are generally considered constant over time and uses. CALEB uses EIA's annual 
U.S.-specific conversion factor for liquefied petroleum gas (LPG), which reflects the quantity-weighted average of their components that may fluctuate over time. The national average conversion factor for crude oil is used for the crude oil produced in and imported to California (U.S. EIA, 2003a). For motor gasoline, CALEB uses an annual California-specific conversion factor calculated by the Energy Commission (Bemis, 2004).

Combustion of hydrocarbons results in the production of $\mathrm{CO}_{2}$, water vapor, and heat. In the U.S., the heat value of a product is generally given in British thermal units (Btu) and includes the latent heat in condensation of the water vapor produced during the combustion process. This value is commonly referred to as the gross or higher heating value (HHV). Internationally, however, the lower heating value (LHV) is used with the Système International (SI) energy units (joules or tons of oil equivalent, toe). For coal and oil, the LHV is $5 \%$ less than the HHV; for most forms of natural and manufactured gas the difference is $9 \%-10 \%$. To reflect those national and international conventions, data in the CALEB database are available in Btu in HHV, and in joules or toe in LHV.

\subsection{Greenhouse Gas Conversions}

Once an energy balance has been constructed, $\mathrm{CO}_{2}$ emissions resulting from fossil fuel combustion can be calculated. CALEB has been designed to calculate $\mathrm{CO}_{2}$ emissions from energy consumption. According to the Intergovernmental Panel on Climate Change (IPCC), conversion of fuel combustion to $\mathrm{CO}_{2}$ emissions requires three types of carbon factors: (1) emission factors, (2) storage factors, and (3) oxidation factors (IPCC, 1996). Carbon emission factors convert the fuel consumed into the maximum amount of carbon that can be released in the atmosphere during combustion. Factors specific to the United States are available (U.S.EIA, 2003d). Carbon storage factors are applied to the share of carbon stored when consuming fuel for non-energy purposes. Non-energy uses include, but are not limited to, feedstock use in the petrochemical industry, asphalt and road oil use for road construction, and lubricants. Because data on non-energy uses are difficult to obtain, the consumption of lubricants and asphalt and road oil are assumed to be consumed for non-energy purposes and the storage factors available in the California GHG inventory (CEC, 2002a) were used. ${ }^{1}$ Finally, carbon oxidation factors are the proportion of carbon in fuel that is oxidized to $\mathrm{CO}_{2}$ during combustion. A small proportion of carbon is stored in solids such as ash and soot arising from incomplete combustion of carbon in fuel. Values from the IPCC are used for those factors (IPCC, 1996). Further details regarding calculation of $\mathrm{CO}_{2}$ emissions related to energy consumption are available in Section 8.

\footnotetext{
${ }^{1}$ Although these products are assumed to be used entirely for non-energy uses, this does not imply that they are never oxidized. CALEB uses the assumptions described in the California inventory (CEC, 2002a).
} 


\section{California Energy and Electricity Balances - 2000}

\subsection{California Energy Balance for 2000}

Table 2 provides the California energy balance for 2000. Note that due to independent rounding the totals in Table 2 (and many others in this report) frequently do not match the sum of the underlying items.

Table 2. California energy balance, 2000

\begin{tabular}{|c|c|c|c|c|c|c|c|c|c|c|c|}
\hline TBtu & Nat Gas & NGL & $\begin{array}{l}\text { Crude \& } \\
\text { Additives }\end{array}$ & $\begin{array}{l}\text { Petro } \\
\text { Prods }\end{array}$ & Coal & Nuclear & Hydro & $\begin{array}{l}\text { Other } \\
\text { Ren }\end{array}$ & Biomass & Electricity & Total \\
\hline Energy Supply & 2,252 & 32 & 3,965 & -547 & 136 & 364 & 134 & 434 & 90 & 247 & 7,107 \\
\hline Indigenous Production & 357 & 32 & 1,795 & 0 & 0 & 364 & 134 & 434 & 85 & 0 & 3,201 \\
\hline Import & 1,885 & 0 & 2,224 & 470 & 135 & 0 & 0 & 0 & 5 & 247 & 4,966 \\
\hline Export & -37 & 0 & -39 & -782 & 0 & 0 & 0 & 0 & 0 & 0 & -858 \\
\hline Internatl Marine Bunkers & 0 & 0 & 0 & -230 & 0 & 0 & 0 & 0 & 0 & 0 & -230 \\
\hline Net Stock Withdrawal & 47 & 0 & -15 & -5 & 1 & 0 & 0 & 0 & 0 & 0 & 28 \\
\hline Statistical Differences & 226 & -6 & 4 & -87 & -64 & 0 & 0 & 0 & 1 & 17 & 91 \\
\hline Transformation Sector & -978 & -15 & $-3,969$ & 4,078 & -24 & -364 & -134 & -434 & -91 & 710 & $-1,220$ \\
\hline Electric Sector & -942 & $\mathbf{0}$ & $\mathbf{0}$ & -50 & -24 & -364 & -134 & -434 & -85 & 710 & $-1,322$ \\
\hline CHP, Commercial Power & -13 & 0 & 0 & 0 & 0 & 0 & 0 & 0 & 0 & 6 & -8 \\
\hline CHP, Electric Power & -151 & 0 & 0 & -10 & -21 & 0 & 0 & 0 & 0 & 79 & -103 \\
\hline CHP, Industrial Power & -90 & 0 & 0 & -24 & -3 & 0 & 0 & 0 & 0 & 57 & -61 \\
\hline Electric Generators, Utilities & -130 & 0 & 0 & -2 & 0 & -364 & -130 & 0 & 0 & 292 & -332 \\
\hline Electric Generators, IPP & -558 & 0 & 0 & -14 & 0 & 0 & -4 & 0 & 0 & 200 & -377 \\
\hline Non-specified (Elec. Generation) & 0 & 0 & 0 & 0 & 0 & 0 & 0 & -434 & -85 & 77 & -442 \\
\hline Oil Refineries & -36 & -15 & $-3,969$ & 4,128 & $\mathbf{0}$ & $\mathbf{0}$ & $\mathbf{0}$ & $\mathbf{0}$ & -6 & 0 & 103 \\
\hline Energy Sector & -390 & $\mathbf{0}$ & $\mathbf{0}$ & -312 & $\mathbf{0}$ & $\mathbf{0}$ & $\mathbf{0}$ & $\mathbf{0}$ & $\mathbf{0}$ & -34 & -736 \\
\hline Power Plants' Own Use & 0 & 0 & 0 & 0 & 0 & 0 & 0 & 0 & 0 & 0 & 0 \\
\hline Oil Refineries' Own Use & -106 & 0 & 0 & -311 & 0 & 0 & 0 & 0 & 0 & -21 & -437 \\
\hline Oil and Gas Extraction & -285 & 0 & 0 & -1 & 0 & 0 & 0 & 0 & 0 & -13 & -299 \\
\hline
\end{tabular}

\begin{tabular}{|l|llllllllllll}
\hline Distribution Losses & 0 & 0 & 0 & 0 & 0 & 0 & 0 & 0 & 0 & -77 & -77 \\
\hline
\end{tabular}

\begin{tabular}{|l|rrrrrrrrr|r|r|r}
\hline End Use Sector Consumption & $\mathbf{1 , 1 1 0}$ & $\mathbf{1 2}$ & $\mathbf{0}$ & $\mathbf{3 , 1 3 2}$ & $\mathbf{4 8}$ & $\mathbf{0}$ & $\mathbf{0}$ & $\mathbf{0}$ & $\mathbf{0}$ & $\mathbf{8 6 3}$ & $\mathbf{5 , 1 6 5}$ \\
\hline Agriculture & 18 & 0 & 0 & 61 & 0 & 0 & 0 & 0 & 0 & 22 & 101 \\
Mining & 6 & 0 & 0 & 0 & 0 & 0 & 0 & 0 & 0 & 3 \\
Manufacturing Sector & 231 & 12 & 0 & 100 & 47 & 0 & 0 & 0 & 0 & 136 \\
Transport Sector & 13 & 0 & 0 & 2,754 & 0 & 0 & 0 & 0 & 0 & 525 \\
Services & 299 & 0 & 0 & 20 & 1 & 0 & 0 & 0 & 0 & 375 \\
Residential & 529 & 0 & 0 & 27 & 0 & 0 & 0 & 0 & 0 & 275 \\
Non-specified (Other Sector) & 14 & 0 & 0 & 0 & 0 & 0 & 0 & 0 & 0 & 431 \\
Non-Energy Use & 0 & 0 & 0 & 170 & 0 & 0 & 0 & 0 & 0 \\
\end{tabular}

\begin{tabular}{|l|rrrrrrrrrr|r|r|}
\hline Electricity Output in GWh & $\mathbf{1 0 3 , 2 3 6}$ & $\mathbf{0}$ & $\mathbf{0}$ & $\mathbf{5 , 5 2 7}$ & $\mathbf{2 , 3 6 4}$ & $\mathbf{3 5 , 1 7 6}$ & $\mathbf{3 9 , 2 7 2}$ & $\mathbf{1 6 , 3 4 1}$ & $\mathbf{6 , 1 8 4}$ & $\mathbf{0}$ & $\mathbf{2 0 8 , 1 0 0}$ \\
\hline CHP, Commercial Power (GWh) & 1,710 & 0 & 0 & 1 & 0 & 0 & 8 & 0 & 0 & 0 & 1,719 \\
CHP, Electric Power (GWh) & 20,188 & 0 & 0 & 961 & 1,902 & 0 & 0 & 0 & 0 & 0 \\
CHP, Industrial Power (GWh) & 12,992 & 0 & 0 & 3,095 & 461 & 0 & 0 & 22 & 0 & 0 \\
Electric Generators, Utilities (GWh) & 12,412 & 0 & 0 & 145 & 0 & 35,176 & 37,980 & 0 & 0 & 0 \\
Electric Generators, IPP (GWh) & 55,934 & 0 & 0 & 1,325 & 0 & 0 & 1,284 & 0 & 0 & 0 \\
Non-specified (Elec. Generation, GWh) & 0 & 0 & 0 & 0 & 0 & 0 & 0 & 16,319 & 6,184 \\
\hline
\end{tabular}

Notes: Nat Gas = natural gas, NGL = natural gas liquids, Petro Prods = petroleum products, Other Ren = other renewables,

$\mathrm{CHP}=$ combined heat \& power, IPP = independent power producers, GWh = gigawatt-hour

The "Energy Supply" section accounts for all energy produced within the state from primary energy sources and the imports and exports of primary and secondary energy. 
The line labeled "Statistical Differences" is the difference between the total of the end use consumption sector plus the transformation sector (accounting for distribution losses) minus the total energy supplied. It represents energy that is currently unaccounted for within the balance. A negative figure indicates excess supply, and a positive figure indicates excess consumption. A total of 90 trillion Btu (TBtu) of energy - more than 1\% of the state's energy that year-remains unaccounted for in the 2000 supply. ${ }^{2}$

The second main section, "Transformation Sector," accounts for the energy consumed to produce electricity and petroleum products within the state, including energy used by the electricity producers and oil refineries. The electricity sector is disaggregated into five types of energy providers. These consist of (1) combined heat and power (CHP), ${ }^{3}$ commercial power; (2) CHP, electric power; (3) CHP, industrial power; (4) electric generators, utilities; and (5) electric generators, independent power producers (IPPs). ${ }^{4}$ There is also non-specified ${ }^{5}$ generation if additional data are reported that are not ascribed specifically to one of these types of producers. Also shown in the transformation section are the crude oil inputs and petroleum product outputs of oil refineries. Energy used by entities to extract and transform energy is reported in the "Energy Sector" portion of this section.

The "Distribution Losses" line accounts for the transmission and distribution (T\&D) losses of the electric system.

The third main section, "End Use Sector Consumption," accounts for the consumption of energy by end use sector. End use sectors include agriculture, mining, manufacturing, transport, services (also called commercial), residential, non-specified (other), and non-energy use. Non-energy uses include inputs of crude oil, petroleum products, and natural gas for the manufacture of materials such as asphalt, lubricants, waxes, and petrochemicals. ${ }^{6}$

The fourth main section, "Electricity Output in GWh," provides supplemental information on electricity production by breaking out the generation of electricity by fuel type. Without this section, the transformation sector data only shows total generation, while inputs are shown by fuel type. The breakout of generation by fuel type is provided, because it is often useful for analytical purposes. Following the IEA convention, these figures are given in gigawatt-hours (GWh).

\footnotetext{
${ }^{2}$ Additional research may permit the narrowing of this statistical difference, but statistical differences of this size are not uncommon among the IEA countries (IEA, 2003a).

${ }^{3} \mathrm{CHP}$ (Combined Heat and Power) is also referred to as cogeneration or cogen.

${ }^{4}$ The EIA defines an IPP as an entity that "owns or operates facilities for the generation of electricity for use primarily by the public, and that is not an electric utility." Similarly, "CHP, Electric Power" facilities are defined as those whose primary business is to sell electricity, as opposed to facilities whose primary function is to provide power in support of a site's industrial or commercial activities (U.S. EIA, 2003b).

${ }^{5}$ The term "non-specified" in the energy balances refers to cases where data were available at a highly aggregated level and could not be allocated to a more specific sub-sector (e.g., motor gasoline consumed for transport with no breakdown by vehicle type would be labeled "transport (non-specified)").

${ }^{6}$ Although the simplified balance shown in Table 1 depicts consumption figures as negative to make the point that consumption figures should balance supply numbers, in practice the IEA balances show end-use consumption as positive numbers and consumption within the transformation sector as negative, so that end-use consumption equals domestic supply adjusted for energy used in the transformation sector.
} 
Figure 1 depicts the data from Table 2 as an energy flow chart. ${ }^{7}$ This chart is similar in format to that produced by Kaiper (2003). Reading from left to right, the figure shows all the inputs of primary (and imported secondary) energy into California's economy in 2000. These are summed by major fuel types in the middle of the figure: petroleum and associated products, natural gas, coal, and inputs to electricity generation. The right side shows how all of the fuels are allocated to the various end uses. Most of the quantities shown in Figure 1 are easily traced to the data from Table 2. Additionally, the agriculture, mining, and manufacturing sectors have been aggregated into an "Industrial” sector in the graphic.

\footnotetext{
${ }^{7}$ Due to rounding, some figures may differ slightly from those shown in Table 2.
} 


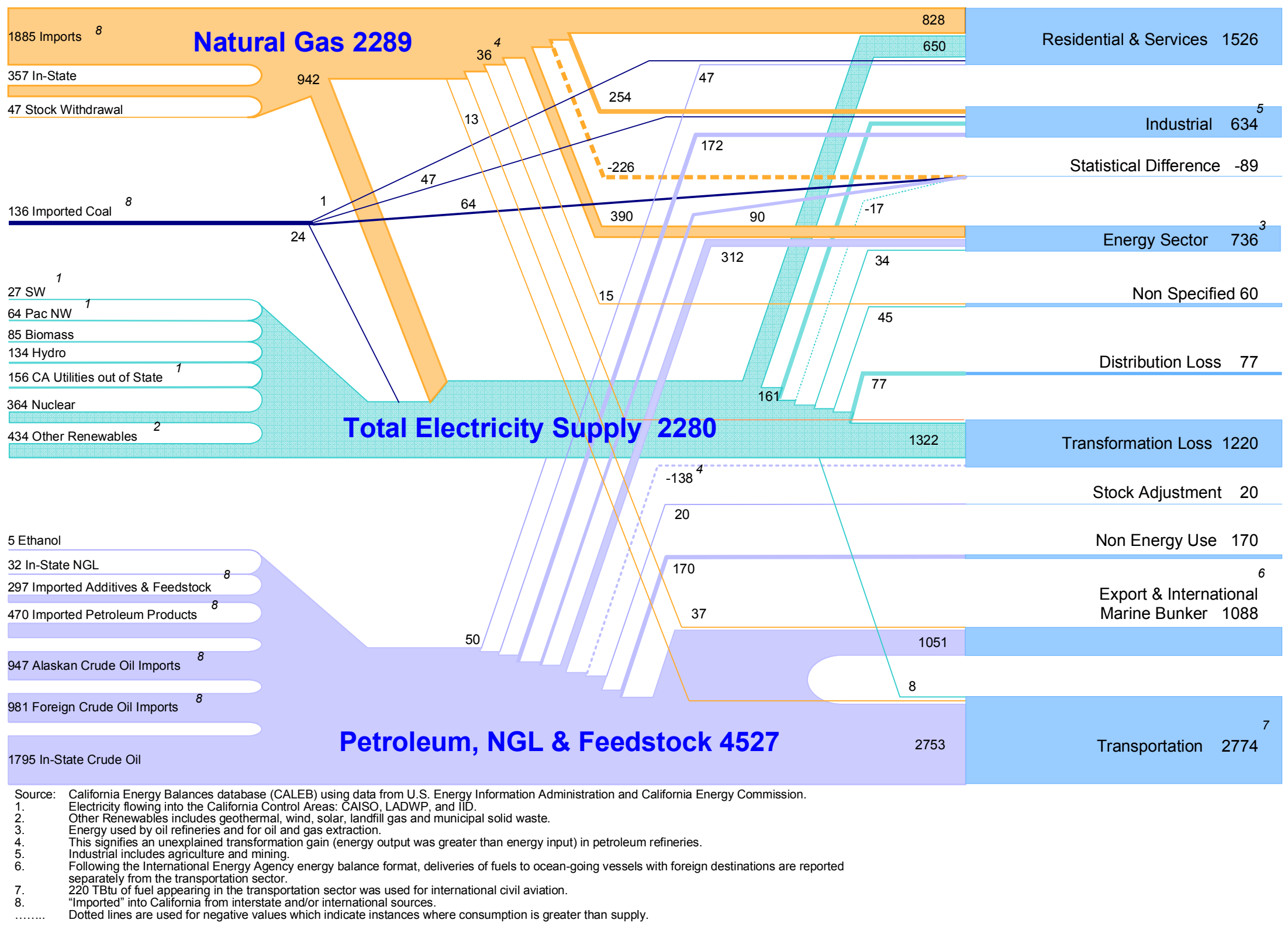

Figure 1. California energy flows in 2000, trillion Btu 


\subsection{California Electricity Balance for $\mathbf{2 0 0 0}$}

Table 3. California electricity balance, 2000

Table 3 shows an electricity balance for the State of California for 2000. Electricity supply is broken out by the type of fuel used to produce the electricity and then further divided by generation type.

In 2000, 208,100 GWh of electricity were produced in the state and 72,397 GWh were imported, for a total domestic electricity supply of 280,496 GWh. Natural gas was the main energy commodity used in the production of electricity, representing $37 \%$ of total electricity supplied. Hydropower supplied 14\%, nuclear 12\%, renewables $8 \%$, petroleum products $2 \%$ and coal $1 \%$. Note that imports of electricity represent $26 \%$ of the electricity supplied.

Electricity consumed in California is divided between electricity used to produce other energy forms - such as electricity used by oil refineries and for oil and gas extraction-and electricity used by the end-use sectors. Electricity T\&D losses are also accounted for in this section. In 2000, 10,075 GWh of electricity were consumed in order to produce other forms of energy, while 253,055 GWh were consumed by the end-use sectors. T\&D losses that year were $22,440 \mathrm{GWh}$. Thus, total electricity consumption in 2000 was 285,570 GWh, which was 5,074 GWh higher than the total electricity supply, resulting in a statistical difference of about $2 \%$ of total supply.

\begin{tabular}{|c|c|}
\hline Electricity Supply & GWh \\
\hline Natural Gas & 103,236 \\
\hline CHP, Commercial Power & 1,710 \\
\hline CHP, Electric Power & 20,188 \\
\hline CHP, Industrial Power & 12,992 \\
\hline Electric Generators, Utilities & 12,412 \\
\hline Electric Generators, IPP & 55,934 \\
\hline Petroleum Products & 5,527 \\
\hline CHP, Commercial Power & 1 \\
\hline CHP, Electric Power & 961 \\
\hline CHP, Industrial Power & 3,095 \\
\hline Electric Generators, Utilities & 145 \\
\hline Electric Generators, IPP & 1,325 \\
\hline Coal & 2,363 \\
\hline CHP, Electric Power & 1,902 \\
\hline CHP, Industrial Power & 461 \\
\hline Nuclear & 35,176 \\
\hline Electric Generators, Utilities & 35,176 \\
\hline Hydro & 39,272 \\
\hline CHP, Commercial Power & 8 \\
\hline Electric Generators, Utilities & 37,980 \\
\hline Electric Generators, IPP & 1,284 \\
\hline Other & 22,525 \\
\hline Geothermal & 12,308 \\
\hline Wind & 3,518 \\
\hline Solar & 493 \\
\hline Wood & 3,574 \\
\hline Landfill \& MSW & 1,938 \\
\hline Other Biomass & 673 \\
\hline Other Gen & 22 \\
\hline Total Net Production & 208,100 \\
\hline Import & 72,397 \\
\hline Total Domestic Supply & 280,496 \\
\hline Statistical Differences & 5,074 \\
\hline Total Consumption & 285,570 \\
\hline Energy Sector & 10,075 \\
\hline Oil Refineries' Own Use & 6,230 \\
\hline Oil and Gas Extraction & 3,845 \\
\hline End Use Sector Consumption & 253,055 \\
\hline Agriculture & 6,449 \\
\hline Mining & 822 \\
\hline Manufacturing Sector & 39,800 \\
\hline Transport Sector & 2,347 \\
\hline Services & 109,908 \\
\hline Residential & 80,612 \\
\hline Non-specified (Other Sector) & 13,117 \\
\hline T\&D Losses & 22,440 \\
\hline
\end{tabular}




\section{Energy Supply}

The energy supply phase of an energy balance documents those flows of energy that are available to the economy prior to transformation and consumption. The energy supply flow includes indigenous energy production, imports, exports, and net stock withdrawals.

Indigenous energy production accounts for the primary energy extracted from within the country (or state). This category consists only of primary forms of energy such as natural gas, crude oil, coal, and production of primary electricity. Fuels derived from primary sources are discussed in Section 5 (Transformation). The heat content of the energy released for production of electricity from nuclear, geothermal, biomass, municipal solid wasted, and landfill gas is also shown in this category.

Imports of energy include imported primary energy products, as well as secondary products such as refined petroleum products and electricity. These secondary products are not shown in the transformation sector, because the process of transforming the energy does not occur within state boundaries. Exports, likewise, include all energy sources shipped outside of California's borders.

International marine bunkers indicate deliveries of liquid fuels to ocean-going vessels for international destinations. In the IEA balances, only the fuel used for international marine bunkers is deducted from domestic energy supply. In contrast, fuel used for international aviation is included in the end-use consumption totals, although it is reported separately from fuel used for domestic aviation. For the purposes of constructing national GHG inventories, the IPCC recommends that emissions from all international bunker fuels, both maritime and aviation, be excluded from national totals (IPCC, 1996). The reporting guidelines request that international bunker deliveries be reported along with a description of the method used to estimate the international portion of marine and aviation fuel deliveries. ${ }^{8}$

The treatment of international bunker fuels presents a number of methodological and statistical challenges. Ideally, fuel consumption and delivery data would be sufficiently detailed to permit a careful disaggregation following the guidelines provided by the United Nations Framework Convention on Climate Change (UNFCCC, 2003). In practice, deliveries of these fuels are not reported separately for domestic and international trips. Thus, estimation methods must be used to allocate the fuel consumption accordingly. For example, a previous study (Schipper and McMahon, 1995) estimated that only 6\% of jet fuel sold in the state is used for intrastate travel. A detailed discussion of the data sources and methods used to allocate marine bunker fuels to international and domestic transportation is given below in Section 4.2.2. Since fuel consumed for international aviation appears in the transport sector in the IEA tables, the methodology for allocating aviation fuels appears in Section 6.3.2.

\footnotetext{
${ }^{8}$ A recent United Nations Framework Convention on Climate Change (UNFCCC) methodological note (UNFCCC, 2003) compares the definitions of international versus domestic trips used by the IPCC and the IEA, as well as those used by the International Civil Aviation Organization (ICAO) and the International Maritime Organization (IMO). This document discusses collaborative efforts by these organizations to harmonize their approaches and improve the data.
} 
Net stock withdrawal indicates the net quantities of fuels taken from or added to stock over the course of the year. A positive number shows that a net amount of fuel was withdrawn from stock and thus contributed to the year's supply. A negative number means that overall, fuel has been added to stock, reducing the quantity made available to the transformation or consumption flows. For natural gas, net stock withdrawal equals the natural gas withdrawn either from underground storage or liquefied natural gas (LNG) storage.

Because domestic production and imports are always shown as positive numbers, and exports and marine bunkers are shown as negative numbers, the sum of all the supply flows for any given product results in the total amount of energy from that source for that year.

\subsection{Natural Gas}

\subsubsection{Trends}

California's total natural gas supply increased from 1,980 billion cubic feet (2,042 TBtu) in 1990 to 2,422 billion cubic feet (2,368 TBtu) in 2001 (see Table 4). Historically low indigenous natural gas production was experienced in the mid-1990s, but production has increased over the past few years.

California relies heavily on imported natural gas. Table 4 shows that only about $15 \%$ of the natural gas supply is from in-state sources. Almost half of California's natural gas is imported from the southwest United States, a little over one quarter from Canada, and the remainder from the Rocky Mountain states, which only began supplying natural gas to California in 1992 (CEC, 2004c; CEC 2004d). Overall natural gas supply in the state is projected to increase 14\% between 2003 and 2013, with most of the growth in imports from the Rocky Mountain region (Braithwaite et al., 2003).

Table 4. California supply of natural gas, 1990 to 2001

\begin{tabular}{|l|r|r|r|r|r|r|r|r|r|r|r|r|}
\hline Billion Cubic Feet & 1990 & 1991 & 1992 & 1993 & 1994 & 1995 & 1996 & 1997 & 1998 & 1999 & $\mathbf{2 0 0 0}$ & $\mathbf{2 0 0 1}$ \\
\hline Indigenous Production & 350 & 367 & 353 & 304 & 298 & 268 & 274 & 274 & 305 & 372 & 366 & 367 \\
Import & 1,620 & 1,624 & 1,611 & 1,654 & 1,887 & 1,691 & 1,548 & 1,671 & 1,820 & 1,795 & 1,928 & 2,166 \\
Export & 0 & 0 & 0 & 0 & 0 & 0 & 0 & 0 & -2 & -4 & -38 & -46 \\
Net Stock Withdrawal & 9 & 12 & -28 & 29 & 5 & 27 & -51 & 16 & -41 & 8 & 48 & -65 \\
\hline Total & 1,980 & 2,003 & 1,936 & 1,987 & 2,190 & 1,986 & 1,771 & 1,961 & 2,082 & 2,172 & 2,304 & 2,422 \\
\hline
\end{tabular}

\begin{tabular}{|l|r|r|r|r|r|r|r|r|r|r|r|r|}
\hline Trillion Btu & $\mathbf{1 9 9 0}$ & $\mathbf{1 9 9 1}$ & $\mathbf{1 9 9 2}$ & $\mathbf{1 9 9 3}$ & $\mathbf{1 9 9 4}$ & $\mathbf{1 9 9 5}$ & $\mathbf{1 9 9 6}$ & $\mathbf{1 9 9 7}$ & $\mathbf{1 9 9 8}$ & $\mathbf{1 9 9 9}$ & $\mathbf{2 0 0 0}$ & $\mathbf{2 0 0 1}$ \\
\hline Indigenous Production & 361 & 376 & 363 & 315 & 304 & 272 & 283 & 279 & 321 & 379 & 357 & 359 \\
Import & 1,671 & 1,667 & 1,655 & 1,717 & 1,926 & 1,713 & 1,599 & 1,701 & 1,914 & 1,827 & 1,885 & 2,117 \\
Export & 0 & 0 & 0 & 0 & 0 & 0 & 0 & 0 & -2 & -4 & -37 & -45 \\
Net Stock Withdrawal & 10 & 13 & -29 & 20 & 5 & 28 & -53 & 17 & -43 & 8 & 47 & -63 \\
\hline Total & 2,042 & 2,056 & 1,989 & 2,052 & 2,235 & 2,012 & 1,829 & 1,996 & 2,190 & 2,210 & 2,253 & 2,368 \\
\hline
\end{tabular}




\subsubsection{Data Sources and Data Issues}

The primary source for all natural gas supply data is the EIA's Natural Gas Navigator (U.S. EIA, 2005a; U.S. EIA, 2005b). Production data are collected by the California Department of Conservation and reported to the EIA. Alternate production data are also available from statistics compiled by the Energy Commission from the California Department of Conservation (Wood, 2004). The EIA figures are broken down into two different sets: production and marketed production. The EIA figures for marketed production tend to be slightly higher than the dry basis Energy Commission numbers; whereas the production figures, which are corrected for the extraction losses of natural gas liquids, tend to be slightly lower. This difference may be due to the Energy Commission methodology of assuming 5\% shrinkage of natural gas from associated oil fields. An alternate source of production and import data is available from the Energy Commission (CEC, 2004d).

\subsection{Crude Oil and Petroleum Products}

\subsubsection{Trends}

California produces slightly less than half of its crude oil and imports the remainder. The total supply of crude oil in California, as shown in Table 5, dropped from 710,983 thousand barrels (kbbl) (4,124 TBtu) in 1990 to 625,200 kbbl (3,626 TBtu) in 2001. Imports of crude oil fluctuated throughout the period, settling to about 330,000 kbbl (2000 TBtu) during the last three years.

Currently, about $30 \%$ of California's crude oil is imported from foreign countries (predominately from Iraq, Saudi Arabia, Ecuador, and Mexico), and the remaining 20\% is imported from Alaska (CEC, 2004e). Figure 2 shows trends in the overall California crude oil supply for 1982 to 2001, and Figure 3 shows the breakdown of California's foreign imports of crude oil in 2002 (CEC, 2004f; California Department of Conservation, various years).

Table 5. California supply of crude oil, 1990 to 2001

\begin{tabular}{|c|c|c|c|c|c|c|c|c|c|c|c|c|}
\hline Thousand Barrels & 1990 & 1991 & 1992 & 1993 & 1994 & 1995 & 1996 & 1997 & 1998 & 1999 & $2000^{b}$ & 2001 \\
\hline $\begin{array}{l}\text { Indigenous } \\
\text { Production }^{\mathrm{a}}\end{array}$ & 350,656 & 350,838 & 348,183 & 343,660 & 344,533 & 351,320 & 347,264 & 340,362 & 331,234 & 311,535 & 307,430 & 293,745 \\
\hline Import & 360,327 & 346,838 & 332,708 & 328,924 & 346,209 & 321,384 & 345,120 & 322,552 & 326,636 & 329,342 & 332,338 & 331,672 \\
\hline Export & 0 & 0 & 0 & 0 & 0 & 0 & -297 & -715 & -211 & -585 & 0 & -217 \\
\hline Total & 710,983 & 697,676 & 680,891 & 672,584 & 690,742 & 672,704 & 692,087 & 662,199 & 657,659 & 640,292 & 639,768 & 625,200 \\
\hline Trillion Btu & 1990 & 1991 & 1992 & 1993 & 1994 & 1995 & 1996 & 1997 & 1998 & 1999 & 2000 & 2001 \\
\hline $\begin{array}{l}\text { Indigenous } \\
\text { Production }\end{array}$ & 2,034 & 2,03 & 019 & 993 & y & U. & 0 & 74 & $y$ & 8 & 783 & 4 \\
\hline Import & 2,090 & 2,012 & 1,930 & 1,908 & 2,008 & 1,864 & 2,002 & 1,871 & 1,894 & 1,910 & 1,928 & 1,924 \\
\hline Export & 0 & 0 & 0 & 0 & 0 & 0 & -2 & -4 & -1 & -3 & 0 & -1 \\
\hline Total & 4,124 & 4,047 & 3,949 & 3,901 & 4,006 & 3,902 & 4,014 & 3,841 & 3,814 & 3,714 & 3,711 & 3,626 \\
\hline
\end{tabular}

${ }^{a}$ Indigenous production includes production from the Outer Continental Shelf, which could be considered an import, because that is federal territory.

b Stock change data were also available for 2000. In 2000, 1,623 kbbl (about 9 TBtu) were added to stocks. 


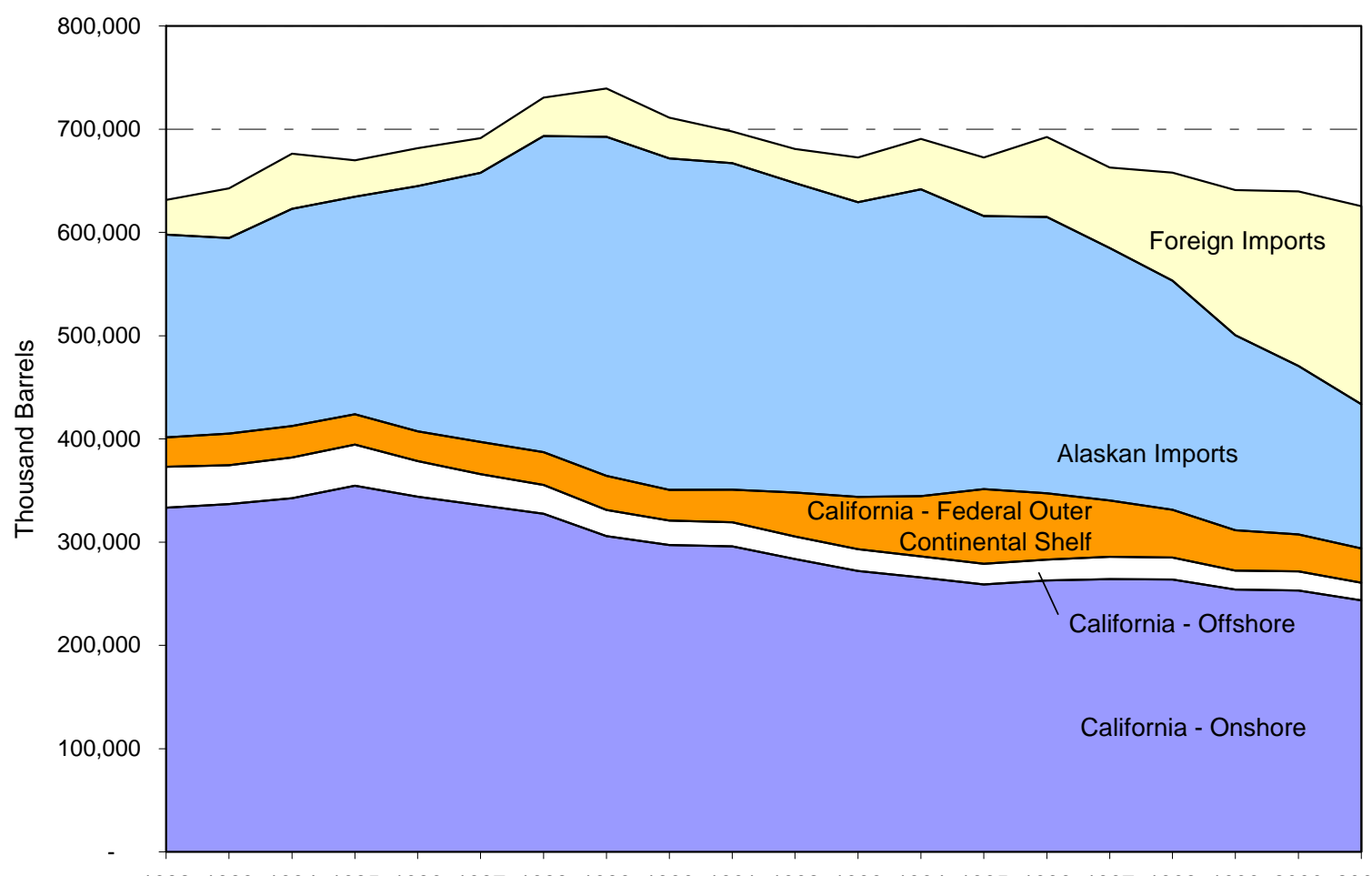

19821983198419851986198719881989199019911992199319941995199619971998199920002001 Source: CEC, 2004e; California Department of Conservation,

Figure 2. Sources of California crude oil, 1982 to 2001

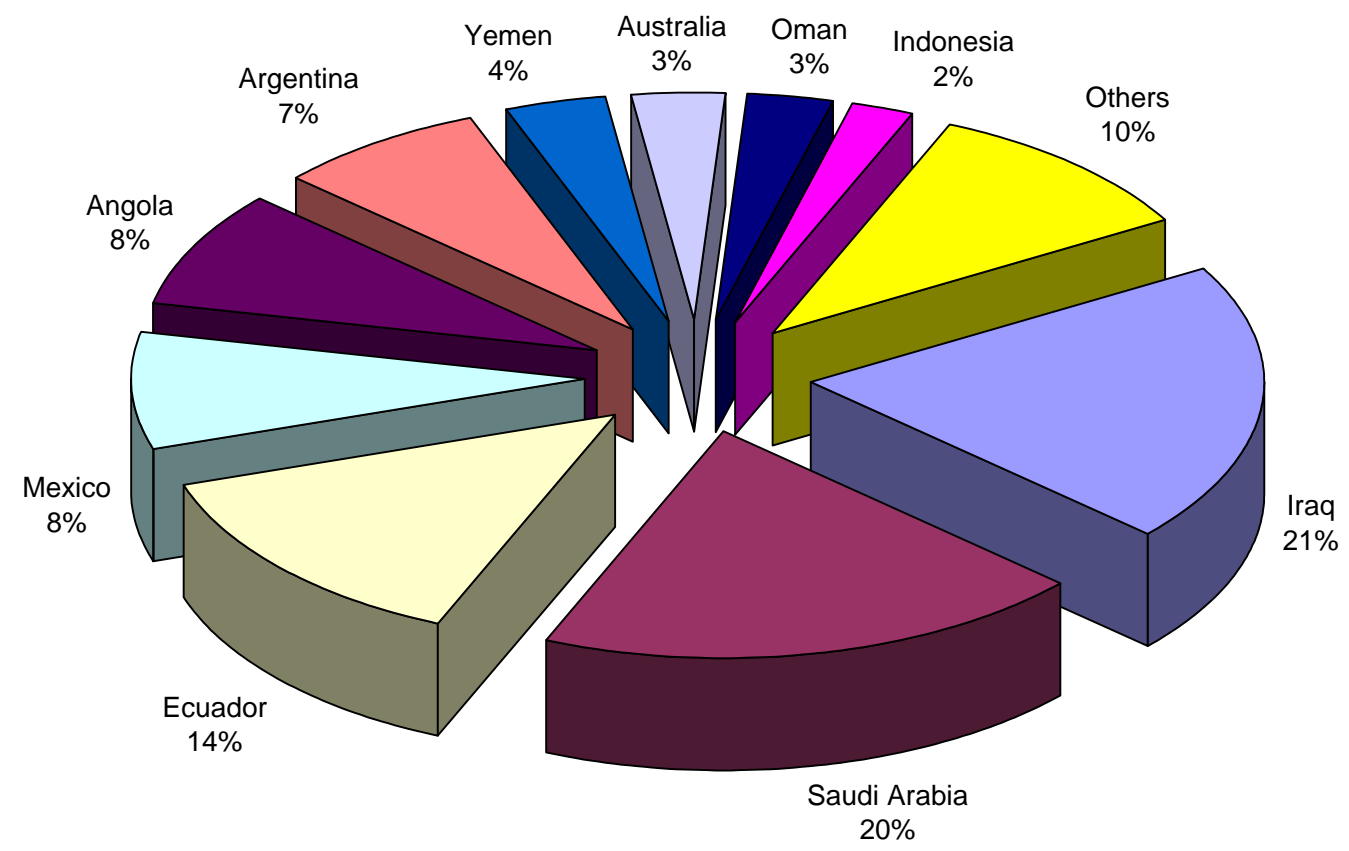

Source: CEC, $2004 f$

Figure 3. Sources of foreign crude oil imported to California, 2002 
Imported and exported additives and refinery feedstocks are shown in Table 6. Feedstocks include materials such as carbon black oil, gas oils, and cracker feeds. Additives are composed of products such as methyl tertiary-butyl ether (MTBE), tertiary amyl methyl ether (TAME), and methanol.

Table 7 shows the trends in the total primary supply of petroleum products. Total imports of petroleum products jumped dramatically in 1999, due to a surge in imports for motor gasoline, jet fuel, and residual fuel oil. Deliveries of bunker fuels fell sharply in 1997 but have increased to previous levels in recent years.

Table 6. Imports and exports of petroleum product additives and feedstocks, 1996 to 2001

\begin{tabular}{|l|r|r|r|r|r|r|}
\hline Thousand Barrels & \multicolumn{1}{|c|}{$\mathbf{1 9 9 6}$} & \multicolumn{1}{|c|}{$\mathbf{1 9 9 7}$} & $\mathbf{1 9 9 8}$ & \multicolumn{1}{c|}{$\mathbf{1 9 9 9}$} & \multicolumn{1}{c|}{$\mathbf{2 0 0 0}$} & $\mathbf{2 0 0 1}$ \\
\hline Import & 47,996 & 53,207 & 58,027 & 69,480 & 67,975 & 59,024 \\
Export & $-11,010$ & $-11,480$ & $-8,779$ & $-11,780$ & $-6,636$ & $-7,352$ \\
Net Stock Withdrawal & 0 & 0 & 0 & 0 & -721 & 0 \\
\hline Total & 36,987 & 41,727 & 49,249 & 57,700 & 60,619 & 51,673 \\
\hline & & & & & & \\
\hline Trillion Btu & $\mathbf{1 9 9 6}$ & $\mathbf{1 9 9 7}$ & $\mathbf{1 9 9 8}$ & $\mathbf{1 9 9 9}$ & $\mathbf{2 0 0 0}$ & $\mathbf{2 0 0 1}$ \\
\hline Import & 209 & 228 & 246 & 312 & 297 & 253 \\
Export & -64 & -67 & -51 & -69 & -39 & -43 \\
Net Stock Withdrawal & 0 & 0 & 0 & 0 & 0 & 0 \\
\hline Total & 209 & 228 & 246 & 312 & 297 & 253 \\
\hline
\end{tabular}

Table 7. California petroleum products, 1995 to 2001

\begin{tabular}{|c|c|c|c|c|c|c|c|}
\hline Thousand Barrels & 1995 & 1996 & 1997 & 1998 & 1999 & 2000 & 2001 \\
\hline Import & 17,288 & 44,802 & 43,984 & 41,011 & 80,641 & 82,264 & 80,732 \\
\hline Export & $-93,037$ & $-143,364$ & $-146,261$ & $-145,172$ & $-156,231$ & $-138,771$ & $-93,884$ \\
\hline Bunker Fuel & $-43,105$ & $-39,565$ & $-22,677$ & $-21,585$ & $-30,822$ & $-36,675$ & $-34,344$ \\
\hline Net Stock Withdrawal & 0 & 0 & 0 & 0 & 0 & -851 & 0 \\
\hline Total & $-118,854$ & $-138,127$ & $-124,954$ & $-125,746$ & $-106,412$ & $-94,033$ & $-47,496$ \\
\hline Trillion Btu & 1995 & 1996 & 1997 & 1998 & 1999 & 2000 & 2001 \\
\hline Import & 99 & 256 & 251 & 234 & 461 & 470 & 461 \\
\hline Export & -532 & -819 & -836 & -829 & -893 & -782 & -536 \\
\hline Bunker Fuel & -270 & -248 & -142 & -135 & -193 & -230 & -215 \\
\hline Net Stock Withdrawal & 0 & 0 & 0 & 0 & 0 & -5 & 0 \\
\hline Total & -703 & -811 & -727 & -730 & -625 & -547 & -290 \\
\hline
\end{tabular}

\subsubsection{Data Sources and Data Issues}

\subsubsection{Crude Production, Imports, and Exports}

The primary crude oil production data used for CALEB are from the California Department of Conservation's Annual Reports of the State Oil \& Gas Supervisor (California Department of Conservation, various years). Imports from Alaska or foreign countries to California refineries are taken from the Petroleum Industry Information Reporting Act (PIIRA) data (CEC, 2004e). Crude oil exports are reported in the Port Import Export Reporting Service (PIERS) database; these exports are very small, amounting to less than $0.1 \%$ of total supply in most years (Journal of Commerce Group, 2004). 
An alternative data source is provided by the EIA's Petroleum Supply Annual, which contains a data series of crude oil production by state (U.S. EIA, various years). The values in this source closely match the Department of Conservation values. Movements of crude oil (whether international or interstate) are shown only at the Petroleum Administration for Defense District (PADD) level, which aggregates California with Washington, Oregon, Nevada, Arizona, Alaska, and Hawaii into District V, so no comparable data series for California imports is available from the EIA (U.S. EIA, 2004b).

\subsubsection{Imports and Exports of Petroleum Products}

Data on movements of intermediate and finished petroleum products (including ethanol for blending into motor gasoline) were obtained from four sources. The U.S. Army Corps of Engineers tracks interstate waterborne shipments of crude oil and petroleum products (U.S. Army Corps of Engineers, 2002). The PIERS database tabulates international maritime shipments of crude oil and petroleum products (Journal of Commerce Group, 2004). Kinder Morgan operates petroleum product pipelines in California and furnishes data to the Energy Commission on movements of petroleum products across state lines. A complete time series of this data was not available at the time this report was written, but data for 2000 were taken from an Energy Commission report (CEC, 2002b). This figure was then used to backcast to 1996. Unfortunately, due to the multiplicity of products involved, each of these three data sources uses its own system of product classifications. The Army Corps data are particularly problematic, because these data are reported in the most aggregated categories, making it impossible to exactly match product flows to the other data sources of production and movement. In addition, the Army Corps does not distribute data on product shipments when less than three operators shipped a given product between a given origin and destination pair of states, resulting in several missing data points. Supplemental data on interstate imports of MTBE in 2000 were taken from Perez (2002) and used to backcast to 1996.

\subsubsection{Estimation of International Marine Bunkers}

Data on total sales of marine bunker fuels (for both domestic and international transit) were provided by the EIA (Walzer, 2004) from the data sets used for the EIA's Fuel Oil and Kerosene Sales reports (U.S. EIA, various years). ${ }^{9}$ The annual consumption of international marine bunker fuels purchased in California is calculated following IEA and IPCC guidelines for allocating purchases of vessel bunkering fuel to international shipping activities. The research team employed the "ship movement methodology" outlined by the European Environment Agency (EEA) in its Emission Inventory Guidebook (EEA, 2004) to estimate the percentage of California's annual transport-sector residual fuel consumption that is used as international marine bunker fuel.

Following the EEA approach, Berkeley Lab first determined the tonnage and commodities shipped from California ports to foreign and domestic destinations using data supplied by the U.S. Waterborne Commerce Statistics Center's (U.S. WCSC) 2000 Commodity Movements

\footnotetext{
${ }^{9}$ This data set reports some sales of residual fuel oil to the military, but it is not clear whether these sales are for vessel bunkering. The data used in CALEB to calculate international and domestic bunker fuels is taken only from the data described as "vessel bunkering" in the EIA data (Walzer, 2004).
} 
report (U.S. WCSC, 2000a). Next, Berkeley Lab chose representative ocean-going vessel types from published EEA data (EEA, 2004) to determine the average fuel intensity (kilogram (kg) fuel/tonne-day) of shipping for each commodity. For example, for shipments of crude petroleum, the "liquid bulk" ocean-going vessel type was selected. Next, estimates were made of the duration of transport from California to foreign and domestic ports for each commodity using average speeds for each ocean-going vessel type (EEA, 2004) and an online port-to-port distance calculator (Distances.com, 2005). Finally, the average duration of transport, average fuel intensity, and annual tonnage shipped were multiplied for each commodity to calculate the total mass of residual fuel consumed for both foreign and domestic shipping from California in 2000. Based on this approach, the research team estimated that $95 \%$ of California's 2000 transport-sector residual fuel consumption was for international marine bunker purposes. The percentage derived for 2000 is applied to all years in the current data set, but future work may entail calculating the domestic and international splits for all years because these splits are likely to fluctuate over time.

Several important assumptions were made to arrive at this estimate for international marine bunker usage of residual fuel. For domestic shipments, the U.S. WCSC Commodity Movements reports provide the tonnage of different commodities shipped from California to each U.S. state but do not provide the specific ports of origin or destination. Berkeley Lab therefore assumed that the port of destination in each U.S. state was the port with the highest annual tonnage within that state. The highest annual tonnage port within each state was identified using the Waterborne Commerce of the United States report series, which tabulates annual shipping and receiving tonnages for all major U.S. ports (U.S. WCSC, 2000b). To estimate the duration of transport from California to a given domestic port for each commodity, Berkeley Lab calculated both the duration of transport from Los Angeles and the duration of transport from San Francisco and took the average of these values. This approach was based on the observation that roughly $85 \%$ of the tonnage shipped from California in 2000 was shipped from ports located in the Los Angeles and San Francisco areas (U.S. WCSC, 2000b).

For foreign shipments, the U.S. WCSC Commodity Movements reports provide only the tonnage of different commodities shipped from California to foreign destinations, and do not provide the specific countries or ports of destination. Berkeley Lab therefore assumed the following breakdown of tonnage shipped from California to foreign destinations for all commodities, based on export partner statistics published by the Port of Long Beach and the Port of Oakland (Port of Long Beach, 2003; Port of Oakland, 2003): China (44\%), Japan (21\%), South Korea (20\%), Taiwan (6\%), Singapore (5\%), Australia (2\%), and Malaysia (2\%). The duration of transport to each foreign destination for all commodities was estimated in the same manner as for domestic shipping.

Berkeley Lab also estimated the percentage of distillate fuel purchased in California in 2000 that was consumed as international marine bunker fuel. Distillate fuel is consumed for vessel bunkering purposes in California by ocean-going vessels, recreational boats, and harbor craft such as tugboats and ferries. However, only the aggregate amount of distillate fuel consumed for all vessel bunkering purposes in California is currently reported in the Fuel Oil and Kerosene Sales reports.. Thus, before the percentage of California distillate fuel consumed as 
international marine bunker fuel could be estimated, the quantity of distillate fuel consumed by ocean-going vessels had to be calculated.

Based on GHG emissions inventory data from the Commission, Berkeley Lab estimated that for every barrel of residual fuel consumed by ocean-going vessels in California, an average of 0.06 barrels of distillate fuel are also consumed (CEC, 2002a), based on the average ratio of distillate fuel carbon emissions to residual fuel carbon emissions from international marine bunker fuels from 1990-1999, as reported by the Commission. ${ }^{10}$ In 2000, EIA reports that 36.4 million barrels of residual fuel were consumed for vessel bunkering purposes in California. Assuming that all residual fuel consumed in California for vessel bunkering is for ocean-going vessels, Berkeley Lab estimates that 2.2 million barrels of distillate fuel were consumed by ocean-going vessels. Applying the same 95\% share of marine bunker fuels used for international transit that was used for residual fuel yields roughly 2.1 million barrels consumed as international marine bunker fuel and 0.1 million barrels consumed for domestic transit.

The EIA Fuel Oil and Kerosene Sales report states that 3.8 million barrels of distillate fuel were sold in California for vessel bunkering purposes in 2000 (U.S. EIA, 2000; Walzer, 2004). Subtracting the estimate of 2.2 million barrels consumed by ocean-going vessels leaves 1.6 million barrels of vessel bunkering distillate fuel consumed by non ocean-going vessels. As a check on this estimate, Berkeley Lab considered that the California Air Resources Board reports that 17.9 million gallons of fuel were consumed by commercial harbor craft such as tugboats, fishing boats, and pilot boats in 2000 (CARB, 2004). Assuming that all harbor craft run on distillate fuel, then commercial harbor craft consumed roughly 420,000 barrels of distillate fuel in California in 2000. Thus, this study found that roughly 1.2 million barrels of vessel bunkering distillate fuel reported in the 2000 Fuel Oil and Kerosene Sales report were not accounted for by these estimates of ocean-going vessel and commercial harbor craft distillate fuel consumption. It is possible that a significant fraction of the remaining 1.2 million barrels of distillate fuel was consumed in 2000 by recreational boats and other marine vessels for which fuel consumption data are not reported. However, this discrepancy suggests that this study's estimate for the distillate fuel consumed as international marine bunkers should be treated as fairly uncertain.

\subsection{Coal}

\subsubsection{Trends}

California's coal supply is made up entirely of imported coal from Colorado, Kentucky, New Mexico, Utah, West Virginia, and Wyoming. Coal imports were relatively steady from 1990 to 1997, at which point they jumped from 2,794 thousand short tons (kst) (65 TBtu) to 4,789 kst (110 TBtu) in 1998 and continued to increase to 7,881kst (179 TBtu) in 2001 (see Table 8). Table 9 shows the sources of imported coal, which are dominated by imports from Utah.

\footnotetext{
${ }^{10}$ This relationship may not always hold when differential prices cause ships to stock up on bunker fuel in other ports, as occurred in California between 1991 and 1993 when a sales tax on marine bunker fuel led to a sharp drop in fuel purchases at California ports (CEC, 2002a).
} 
Table 8. California supply of coal, 1990 to 2001

\begin{tabular}{|c|c|c|c|c|c|c|c|c|c|c|c|c|}
\hline Thousand Short Tons & 1990 & 1991 & 1992 & 1993 & 1994 & 1995 & 1996 & 1997 & 1998 & 1999 & 2000 & 2001 \\
\hline Import & 2,804 & 2,808 & 2,813 & 2,608 & 3,096 & 2,839 & 2,240 & 2,794 & 4,789 & 5,335 & 5,691 & 7881 \\
\hline Net Stock Withdrawal & 0 & -17 & 30 & 16 & -33 & -7 & -17 & 32 & -70 & -4 & 61 & 0 \\
\hline Total & 2,804 & 2,791 & 2,843 & 2,624 & 3,063 & 2,832 & 2,223 & 2,826 & 4,719 & 5,331 & 5,752 & 7881 \\
\hline Trillion Btu & 1990 & 1991 & 1992 & 1993 & 1994 & 1995 & 1996 & 1997 & 1998 & 1999 & 2000 & 2001 \\
\hline Import & 65 & 65 & 65 & 61 & 72 & 66 & 52 & 65 & 110 & 123 & 135 & 179 \\
\hline Net Stock Withdrawal & 0 & 0 & 1 & 0 & -1 & 0 & 0 & 1 & -2 & 0 & 1 & 0 \\
\hline Total & 65 & 65 & 66 & 61 & 71 & 66 & 52 & 65 & 109 & 123 & 136 & 179 \\
\hline
\end{tabular}

Source: Coal Industry Annual and Annual Coal Reports, U.S. EIA (various years)

Table 9. Sources of coal imported to California, 1990 to 2001

\begin{tabular}{|c|c|c|c|c|c|c|c|c|c|c|c|c|}
\hline Thousand Short Tons & 1990 & 1991 & 1992 & 1993 & 1994 & 1995 & 1996 & 1997 & 1998 & 1999 & 2000 & 2001 \\
\hline Colorado & 104 & 107 & 24 & 33 & 22 & 1 & 0 & 47 & 78 & 10 & 136 & 9 \\
\hline New Mexico & 233 & 87 & 12 & 0 & 0 & 0 & 0 & 0 & 0 & 6 & 63 & 197 \\
\hline Utah & 2466 & 2556 & 2777 & 2575 & 3074 & 2838 & 2240 & 2718 & 4711 & 5130 & 5492 & 7322 \\
\hline West Virginia & 0 & 0 & 0 & 0 & 0 & 0 & 0 & 0 & 0 & 0 & 0 & 0 \\
\hline Wyoming & 1 & 58 & 0 & 0 & 0 & 0 & 0 & 29 & 0 & 189 & 0 & 0 \\
\hline Kentucky & 0 & 0 & 0 & 0 & 0 & 0 & 0 & 0 & 0 & 0 & 0 & 353 \\
\hline Total & 2804 & 2808 & 2813 & 2608 & 3096 & 2839 & 2240 & 2794 & 4789 & 5335 & 5691 & 7881 \\
\hline
\end{tabular}

Source: Coal Industry Annual and Annual Coal Reports, U.S. EIA (various years)

\subsubsection{Data Sources and Data Issues}

Import and stock change numbers for coal are taken from the EIA's Coal Industry Annual reports, which from 2001 on have been renamed the Annual Coal Report (U.S.EIA, 1996; U.S.EIA, 2001; U.S.EIA, 2003c). California has no indigenous production of coal. However, data from earlier Coal Industry Annual reports show some limited in-state production of coal. These figures on coal production were later revised and removed from the data series, because it was determined that the product being extracted was montan wax, which is not used for energy purposes and thus does not affect the energy balance. Of greater concern is the abrupt increase in imports reported for more recent years, an increase unmatched by a corresponding increase in consumption. It has been suggested that this increase may be due to coal shipments to out-of-state power plants controlled by California utilities being misreported as delivered to California (Freme, 2004).

\subsection{Electricity Imports and Non-Fossil Electricity Generation Inputs}

Unless imported or exported, electricity per se does not appear in the "Energy Supply" portion of the energy balance. Rather, it is the inputs to electricity generation that are shown. An energy balance distinguishes primary from secondary energy. Primary energy is the energy embodied in natural resources (e.g., coal, crude oil, sunlight, uranium) that has not undergone any anthropogenic conversion or transformation (IPCC, 2001). Secondary energy is the energy contained in products or carriers that result from the transformation or conversion of primary energy (e.g., electricity, petroleum products). This distinction is principally made to avoid double counting the energy supplied. Hence, only the production of primary products 
appears in the top part of the balance under "Energy Supply," and the production of secondary products like electricity appears in the "Transformation Sector" as a result of energy conversion. The fossil fuel supplies for all purposes, including electricity generation, have been described in the preceding sections of this report. This section provides information on electricity imports and the non-fossil inputs to electricity generation.

It is rather straightforward to account for fossil fuel energy input into a power plant, since consumption data on the use of these fuels for electricity generation are generally publicly available. The heat content of other fuels, however, is frequently not reported, and accounting for the energy input from hydro, wind, solar, or nuclear energy poses certain methodological questions. Estimating these energy inputs requires adoption of accounting conventions. There are two different methods used to "back-calculate" the primary energy necessary to produce non-fossil fuel electricity production. The partial substitution method calculates how much primary energy this production of electricity would require if it was generated by fossil fuels. The EIA uses this method in its Annual Energy Review and annually calculates a heat rate factor representing the average efficiency of fossil fueled steam-electric power plants in the U.S. This factor is used to account for the primary energy for hydro, wind and solar electricity (U.S. EIA, 2003e).

The second method, called the physical energy content method, estimates the efficiency of the electricity produced from primary forms of energy. For example, one way to define the primary energy supplied by a hydro generating station would be to simply take the electricity produced as the energy supplied. Because the amount of energy supplied and the amount of electricity ultimately consumed are the same, this implies a conversion efficiency of $100 \%$. In order to represent a more accurate conversion efficiency of hydro turbines, one could calculate the kinetic energy of the water falling through the penstock (either through induction or measurements of water flow during the year) and label this the primary energy supplied. In the methodology section of the Energy Balance publications, the IEA states the principle used in their balances is that "the primary energy form should be the first energy form downstream in the production process for which multiple energy uses are practical" (IEA, 2003a). In other words, if steam turbines are used, the heat used to power the turbines could have been used for a variety of other purposes. Following this convention, the electricity produced is considered the primary form of energy for non-thermal energy sources (e.g., hydro, wind, solar, and wave power). The CALEB database follows the IEA convention of using the physical energy content method and includes the sources of data for primary electricity as well as primary energy (often back-calculated) from electricity generation data from nonfossil-fuels in the supply phase of the database.

For non-fossil thermal energy sources (e.g., nuclear fission, geothermal, biomass, landfill gas, and municipal solid waste), heat is commonly accepted as the primary form of energy in the production of electricity. Primary heat energy for some electricity is generally not measured (or commonly reported) for generation from sources such as the heat produced from nuclear fission and energy from fuels that have little or no other commercial value like landfill gas; municipal solid waste (MSW); wood, wood waste, and other biomass; and geothermal. Because the Renewable Energy Annual reports combine generation of landfill gas and MSW, the heat content of these two sources had to be calculated together (U.S.EIA, various years). 
This was done by examining reported energy inputs at both types of facilities for year 2000 data in the U.S. Environmental Protection Agency's (EPA's) Emissions \& Generation Resource Integrated Database (eGRID) and calculating an average efficiency and applying that to data for all years in CALEB. A similar approach was used for wood and other biomass. The factors derived were 26\% for MSW and landfill gas, 23\% for wood, and 34\% for other biomass (U.S. EPA, 2004a).

Although uranium used to produce heat for steam-generated electricity is not mined within California, it is shown as indigenous production, following IEA convention. The heat content of the steam produced in the boilers is measured, rather than the energy content of the uranium. This quantity is not reported for either of California's two nuclear power plants and is therefore calculated using the standard IEA conversion efficiency of 33\%. Similarly, figures on heat released at operating geothermal units in California are not available and are therefore back-calculated with the standard IEA conversion efficiency of $10 \%$.

Estimation of primary energy for electricity production, therefore, is subject to a variety of accounting conventions that need to be taken into account when constructing an energy balance. For example, using the physical energy content method described above, $10 \mathrm{MBtu}$ of electricity produced requires $10 \mathrm{MBtu}$ of hydro or wind power, but that same $10 \mathrm{MBtu}$ requires $100 \mathrm{MBtu}$ of geothermal heat energy.

\subsubsection{Trends}

The CALEB database uses a geographical boundary for defining imported electricity. Thus, the database counts electricity generated by out-of-state plants partially owned by California utilities as imported electricity, and not as in-state generation. Table 10 shows that imported electricity from the Pacific Northwest (which is predominantly hydro power) and the Southwest (which is predominately coal power) has declined significantly since 1990, while imported electricity from plants owned by California utilities has more than doubled over the time period (CEC, 2003a). Overall, the share of imported electricity declined from 34\% in 1990 to $25 \%$ in 2001.

Table 10. Sources of electricity imported to California, 1990 to 2001 (GWh)

\begin{tabular}{|l|l|l|l|l|l|l|l|l|l|r|r|r|}
\hline Source & $\mathbf{1 9 9 0}$ & $\mathbf{1 9 9 1}$ & $\mathbf{1 9 9 2}$ & $\mathbf{1 9 9 3}$ & $\mathbf{1 9 9 4}$ & $\mathbf{1 9 9 5}$ & $\mathbf{1 9 9 6}$ & $\mathbf{1 9 9 7}$ & $\mathbf{1 9 9 8}$ & $\mathbf{1 9 9 9}$ & $\mathbf{2 0 0 0}$ & $\mathbf{2 0 0 1}$ \\
\hline Pacific Northwest & 31,665 & 28,819 & 19,600 & 15,466 & 15,315 & 19,890 & 29,529 & 25,204 & 19,428 & 26,051 & 18,777 & 6,826 \\
Southwest & 30,294 & 27,054 & 18,104 & 27,426 & 28,040 & 27,624 & 20,167 & 27,517 & 28,135 & 23,436 & 7,997 & 10,000 \\
CA Utility Out-of-State & 24,611 & 27,522 & 30,676 & 12,144 & 27,173 & 27,389 & 28,662 & 29,562 & 39,248 & 37,997 & 45,623 & 49,695 \\
\hline Total & 86,570 & 83,395 & 68,380 & 55,036 & 70,527 & 74,903 & 78,358 & 82,283 & 86,811 & 87,484 & 72,397 & 66,521 \\
\hline
\end{tabular}

Table 11 provides data on non-fossil fuel primary energy used in California to generate electricity. Non-fossil thermal energy includes the assumed heat inputs from sources such as nuclear fission, biomass, geothermal, MSW, and landfill gas used to produce electricity. Production of electricity by these non-fossil heat sources has remained relatively stable during the 1990 to 2001 period. Roughly two-thirds of this electricity comes from nuclear power, a quarter from geothermal, and the remainder from the other sources, such as biomass, landfill gas, and MSW. 
Indigenous production of primary electricity from non-thermal sources (e.g., hydro, wind, solar, and others) has fluctuated dramatically during the period, due largely to fluctuations in hydro power related to annual variations in rainfall and snowpack. The greatest variation in hydro power is seen between the dry years of 1990-1992, 1994, and 2001 and the other wetter years. During the 1990 to 2001 period, electricity from wind power in the state grew at an average annual rate of 1.3\%, increasing from a little over 10 TBtu in 1990 to 12 Btu in 2001. Electricity from solar sources has fluctuated between about 1.8 and 3 TBtu over the period.

Table 11. Non-fossil fuel inputs to electricity generation (trillion Btu)

\begin{tabular}{|c|c|c|c|c|c|c|c|c|c|c|c|c|}
\hline & 1990 & 1991 & 1992 & 1993 & 1994 & 1995 & 1996 & 1997 & 1998 & 1999 & 2000 & 2001 \\
\hline \multicolumn{13}{|l|}{ Heat } \\
\hline Nuclear & 338 & 326 & 364 & 327 & 349 & 313 & 353 & 315 & 358 & 345 & 364 & 343 \\
\hline Geothermal & 477 & 486 & 496 & 494 & 451 & 375 & 398 & 456 & 449 & 445 & 420 & 416 \\
\hline \multicolumn{13}{|l|}{ Electricity } \\
\hline Hydro & 85 & 75 & 69 & 139 & 82 & 172 & 160 & 144 & 173 & 138 & 134 & 86 \\
\hline Wind & 10 & 10 & 10 & 10 & 12 & 11 & 11 & 7 & 9 & 11 & 12 & 12 \\
\hline Solar & 2 & 3 & 3 & 3 & 3 & 3 & 3 & 3 & 3 & 2 & 2 & 2 \\
\hline \multicolumn{13}{|l|}{ Biomass } \\
\hline Wood & 60 & 62 & 60 & 55 & 62 & 41 & 46 & 46 & 41 & 52 & 53 & 49 \\
\hline Landfill \& MSW & 21 & 21 & 21 & 23 & 23 & 23 & 21 & 22 & 21 & 22 & 25 & 24 \\
\hline Other biomass & 6 & 10 & 13 & 13 & 10 & 10 & 7 & 5 & 5 & 7 & 7 & 4 \\
\hline Total & 999 & 993 & 1,035 & 1,063 & 991 & 947 & 998 & 999 & 1,060 & 1,021 & 1,016 & 937 \\
\hline
\end{tabular}

\subsubsection{Data Sources and Data Issues}

The primary energy inputs of non-fossil fuel energy are derived from the in-state generation data described in Section 5.1.1.2 using the physical energy content methodology discussed above.

Electricity imports are calculated as the total net imports given in CEC (2003a), with a correction to estimate the amount of power coming from out-of-state plants partially owned by California utilities. The Energy Commission counts generation from these plants as instate, but for the purposes of the energy balance a strict geographic boundary is used. To do this, the difference between the Energy Commission and the EIA figures for in-state generation was added to the Energy Commission figures for imports. Because the EIA reports state generation totals using a geographic boundary, the differences between the two data series should be due primarily to the out-of-state power counted as in-state by the Energy Commission. Although it is known that California does export some power, it is a net importer, depending on out-of-state supplies for one quarter or more of its electricity needs.

In order to improve the calculations regarding interstate electricity movements, Berkeley Lab is collecting and analyzing detailed data on receipts and deliveries of energy between power control areas. Power control areas report their annual exchanges of electricity with other control areas on the FERC Form 714, although these data are not provided as part of the Form 714 data sets available from the FERC website (FERC, 2005). Berkeley Lab is in the process of obtaining these data directly from the California utilities and control areas and will compare these data with calculations of net imports. 


\section{Transformation}

The transformation phase of an energy balance accounts for two distinct aspects of energy provision: (1) energy inputs that are ultimately converted to secondary sources, and (2) the energy used for the extraction and processing of energy resources (e.g., coal mining, oil and gas extraction, process energy use at refineries). To the extent possible, transformation energy inputs are separated into the energy converted and the energy needed for process heat, pumping, traction, and other demands within transformation facilities.

Table 12 provides data on the transformation phase for the California energy balance for 2000. It shows the energy used by the electric sector, including CHP plants and electric generators (both utilities and IPPs), to produce electricity. The negative values for natural gas, crude oil, coal, nuclear, hydro, other renewables, and biomass indicate energy inputs to produce a total of $710 \mathrm{TBtu}$ of electricity that year. The difference between total inputs of energy for electricity generation and output of electricity (1,322 TBtu), represents the transformation loss.

Oil refineries consumed 3,684 TBtu of crude oil, 300 TBtu of additives and feedstocks (including NGL), and 6 TBtu of ethanol in order to produce 4,128 TBtu of petroleum products, resulting in an unexplained gain of 103 TBtu. For this transformation, 311 TBtu of petroleum products, 106 TBtu of natural gas, and 21 TBtu of electricity were consumed to operate the refineries, as shown in the oil refineries' own use section of the balance. Natural gas (285 TBtu), electricity (13 TBtu), and petroleum products (1 TBtu) were also consumed for oil and gas extraction in the state that year. Additionally, there were an estimated $77 \mathrm{TBtu}$ of T\&D losses.

Table 12. Transformation phase for the California energy balance for 2000 (TBtu)

\begin{tabular}{|c|c|c|c|c|c|c|c|c|c|c|}
\hline & $\begin{array}{c}\text { Natural } \\
\text { Gas }\end{array}$ & \begin{tabular}{c|} 
Crude \& \\
Additives $^{\mathrm{a}}$
\end{tabular} & \begin{tabular}{|c|} 
Petroleum \\
Products
\end{tabular} & Coal & Nuclear & Hydro & $\begin{array}{l}\text { Other } \\
\text { Ren }^{\text {b }}\end{array}$ & Biomass & Electricity & Total \\
\hline Transformation Sector & -978 & $-3,984$ & 4,078 & -24 & -364 & -134 & -434 & -91 & 710 & $-1,220$ \\
\hline Electric Sector & -942 & 0 & -50 & -24 & -364 & -134 & -434 & -85 & 710 & $-1,322$ \\
\hline CHP, Commercial Power & -13 & 0 & 0 & 0 & 0 & 0 & 0 & 0 & 6 & -8 \\
\hline CHP, Electric Power & -151 & 0 & -10 & -21 & 0 & 0 & 0 & 0 & 79 & -103 \\
\hline CHP, Industrial Power & -90 & 0 & -24 & -3 & 0 & 0 & 0 & 0 & 57 & -61 \\
\hline Electric Generators, Utilities & -130 & 0 & -2 & 0 & -364 & -130 & 0 & 0 & 292 & -332 \\
\hline Electric Generators, IPP & -558 & 0 & -14 & 0 & 0 & -4 & 0 & 0 & 200 & -377 \\
\hline Non-specified & 0 & 0 & 0 & 0 & 0 & 0 & -434 & -85 & 77 & -442 \\
\hline Oil Refineries & -36 & $-3,984$ & 4,128 & 0 & 0 & 0 & 0 & -6 & 0 & 103 \\
\hline Energy Sector: Own Use & -390 & 0 & -312 & 0 & 0 & 0 & 0 & 0 & -34 & -736 \\
\hline Power Plants' Own Use & 0 & 0 & 0 & 0 & 0 & 0 & 0 & 0 & 0 & 0 \\
\hline Oil Refineries' Own Use & -106 & 0 & -311 & 0 & 0 & 0 & 0 & 0 & -21 & -437 \\
\hline Oil and Gas Extraction & -285 & 0 & -1 & 0 & 0 & 0 & 0 & 0 & -13 & -299 \\
\hline Distribution Losses & 0 & 0 & 0 & 0 & 0 & 0 & 0 & 0 & -77 & -77 \\
\hline
\end{tabular}

${ }^{\mathrm{a}}$ Includes natural gas liquids (NGLs) and other feedstocks.

b Other renewables includes geothermal, wind, solar, and other miscellaneous renewables. 


\subsection{Electric Sector}

\subsubsection{Inputs}

The transformation phase of the energy balance provides details regarding the inputs into the electricity generation processes. The quantities of natural gas, hydro, and all other energy sources used as inputs are shown as negative values. The total output of electricity from all fuels appears in the electricity column as a positive value.

The electricity sector is disaggregated into five types of energy providers, following the EIA classifications currently used in the Electric Power Annual publications and data sets. These consist of: (1) utilities; (2) IPPs; (3) CHP, electric power sector; (4) CHP, industrial sector; and (5) CHP, commercial sector (see footnote 4). There is also a row for non-specified generation, in case some additional data are reported that are not ascribed specifically to one of these types of producers.

With energy inputs shown as negative numbers and transformation outputs as positive numbers, the "total" column for any of these flows will be equivalent to the total transformation losses. By IEA convention, the total output of electricity should be reported as gross generation, with the power plants' own consumption of electricity and fuels reported in the energy sector under "own use." However, gross generation is rarely reported in U.S. data-only net generation figures are provided. For this reason, the "power plants' own use" flow currently contains no data.

\subsubsection{Trends}

The restructuring of the electric industry that occurred in the late 1990s required California utilities to divest themselves of most of their generating assets. This divestment led to a large shift in generation (and corresponding inputs) from utilities to IPPs. Table 13 shows that the use of petroleum products (primarily refinery gases, petroleum coke, and distillate fuel oil) for production of electricity in California dropped from a high of 66 TBtu in 1990 to 45 TBtu in 2001. Industrial CHP facilities showed a significant growth in use of petroleum products between 1990 and a peak in 1996, but by 2001 consumption returned to roughly the 1990 level. $^{11}$

Natural gas use for production of electricity, on the other hand, increased from 668 billion cubic feet (bcf) in 1990 to 1,023 bcf in 2001 (see Table 14). Most of the growth was experienced by IPPs, especially in 2000 and 2001. The use of coal for electricity production dropped from 1,251 kst in 1990 to 972 kst in 2001 (see Table 15). Most of the decline was experienced by industrial CHP facilities and IPPs, which show no coal consumption after

\footnotetext{
${ }^{11}$ The CHP figures reported by the EIA include the total generation and the corresponding fuel consumption, not just the generation (and fuel input) for power delivered to the grid. The EIA derives the energy input used for electricity from the reported useful thermal output. The energy used for thermal output is calculated by assuming an $80 \%$ conversion efficiency of fuel energy to useful thermal output, and this amount is subtracted from the total reported fuel input. In other words, the energy used to produce electricity is calculated as the remainder of that used for thermal output. The fuel consumed for useful thermal output is reported in the end-use sector where the combustion occurs.
} 
1994. All other fuels used to produce electricity (including nuclear, solar, biomass, geothermal, and others) dropped slightly over the period (see Table 16).

Table 13. Energy inputs to the electricity sector: Petroleum products

\begin{tabular}{|c|c|c|c|c|c|c|c|c|c|c|c|c|}
\hline Billion Cubic Feet & 1990 & 1991 & 1992 & 1993 & 1994 & 1995 & 1996 & 1997 & 1998 & 1999 & 2000 & 2001 \\
\hline Electric Sector & 11,325 & 17,252 & 16,999 & 19,329 & 17,703 & 13,895 & 18,854 & 16,349 & 20,259 & 14,574 & 17,734 & 8,984 \\
\hline CHP, Commercial Power & 1,932 & 1,884 & 1,836 & 1,752 & 1,842 & 0 & 0 & 0 & 1 & 0 & 0 & 0 \\
\hline CHP, Electric Power & 0 & 254 & 2,503 & 1,707 & 1,570 & 1,597 & 693 & 758 & 820 & 499 & 627 & 4 \\
\hline CHP, Industrial Power & 9,387 & 15,108 & 12,653 & 15,869 & 14,291 & 12,296 & 18,156 & 15,591 & 19,439 & 14,076 & 15,962 & 8,980 \\
\hline Electric Generators, Utilities & 0 & 0 & 0 & 0 & 0 & 0 & 0 & 0 & 0 & 0 & 0 & 0 \\
\hline Electric Generators, IPP & 6 & 6 & 6 & 0 & 0 & 2 & 4 & 0 & 0 & 0 & 1,146 & 0 \\
\hline Thousand Barrels & 1990 & 1991 & 1992 & 1993 & 1994 & 1995 & 1996 & 1997 & 1998 & 1999 & 2000 & 2001 \\
\hline Electric Sector & 9,289 & 3,358 & 3,547 & 6,132 & 6,958 & 5,479 & 7,030 & 5,233 & 5,701 & 5,379 & 5,479 & 6,086 \\
\hline CHP, Commercial Power & 18 & 4 & 4 & 7 & 4 & 30 & 37 & 62 & 5 & 2 & 2 & 2 \\
\hline CHP, Electric Power & 16 & 17 & 9 & 8 & 415 & 978 & 1,194 & 1,213 & 1,816 & 1,485 & 1,588 & 1,449 \\
\hline CHP, Industrial Power & 1,020 & 1,018 & 1,437 & 1,267 & 2,041 & 2,079 & 3,079 & 2,250 & 2,150 & 2,196 & 1,314 & 1,166 \\
\hline Electric Generators, Utilities & 7,358 & 1,037 & 605 & 3,336 & 2,959 & 835 & 1,122 & 317 & 278 & 120 & 330 & 648 \\
\hline Electric Generators, IPP & 878 & 1,282 & 1,491 & 1,514 & 1,540 & 1,557 & 1,598 & 1,391 & 1,453 & 1,576 & 2,246 & 2,821 \\
\hline Trillion Btu & 1990 & 1991 & 1992 & 1993 & 1994 & 1995 & 1996 & 1997 & 1998 & 1999 & 2000 & 2001 \\
\hline Electr & -66 & -37 & -38 & -56 & -59 & -46 & -60 & -47 & -54 & -46 & -50 & -45 \\
\hline CHP, Commercial Power & -2 & -2 & -2 & -2 & -2 & 0 & 0 & 0 & 0 & l & 0 & 0 \\
\hline CHP, Electric Power & 0 & 0 & -3 & -2 & -4 & -7 & -8 & -8 & -11 & -9 & -10 & -8 \\
\hline CHP, Industrial Power & -16 & -22 & -21 & -24 & -27 & -25 & -37 & -29 & -33 & -27 & -24 & -16 \\
\hline Electric Generators, Utilities & -43 & -6 & -4 & -19 & -17 & -5 & -7 & -2 & -2 & -1 & -2 & -4 \\
\hline Electric Generators, IPP & -5 & -7 & -9 & -9 & -9 & -9 & -9 & -8 & -8 & -9 & -14 & -16 \\
\hline
\end{tabular}

Table 14. Energy inputs to the electricity sector: Natural gas

\begin{tabular}{|c|c|c|c|c|c|c|c|c|c|c|c|c|}
\hline Billion Cubic Feet & 1990 & 1991 & 1992 & 1993 & 1994 & 1995 & 1996 & 1997 & 1998 & 1999 & 2000 & 2001 \\
\hline Electric Sector & 668 & 673 & 800 & 711 & 851 & 646 & 576 & 639 & 694 & 774 & 940 & 1,023 \\
\hline CHP, Commercial Power & 12 & 11 & 12 & 12 & 13 & 14 & 14 & 13 & 14 & 14 & 13 & 12 \\
\hline CHP, Electric Power & 118 & 123 & 135 & 141 & 145 & 145 & 144 & 153 & 152 & 153 & 151 & 138 \\
\hline CHP, Industrial Power & 77 & 83 & 80 & 81 & 84 & 84 & 93 & 88 & 89 & 90 & 89 & 91 \\
\hline Electric Generators, Utilities & 456 & 449 & 564 & 466 & 601 & 395 & 318 & 378 & 271 & 145 & 129 & 120 \\
\hline Electric Generators, IPP & 4 & 6 & 8 & 11 & 8 & 8 & 6 & 6 & 168 & 372 & 557 & 662 \\
\hline Non-specified & 0 & 0 & 0 & 0 & 0 & 0 & 0 & 0 & 0 & 0 & 0 & 0 \\
\hline Trillion Btu & 1990 & 1991 & 1992 & 1993 & 1994 & 1995 & 1996 & 1997 & 1998 & 1999 & 2000 & 2001 \\
\hline Electric Sec & -689 & -692 & -826 & -733 & -876 & -663 & -591 & -651 & -707 & -778 & -942 & $-1,026$ \\
\hline CHP, Commercial Power & -12 & -11 & -12 & -12 & -14 & -14 & -15 & -14 & -14 & -14 & -13 & -12 \\
\hline CHP, Electric Power & -122 & -127 & -139 & -145 & -149 & -149 & -148 & -156 & -155 & -154 & -151 & -138 \\
\hline CHP, Industrial Power & -79 & -86 & -83 & -84 & -86 & -87 & -96 & -90 & -91 & -90 & -90 & -91 \\
\hline Electric Generators, Utilities & -472 & -462 & -583 & -480 & -619 & -405 & -326 & -385 & -276 & -146 & -130 & -120 \\
\hline Electric Generators, IPP & -4 & -7 & -9 & -12 & -8 & -8 & -6 & -6 & -171 & -375 & -558 & -664 \\
\hline Non-specified & 0 & 0 & 0 & 0 & 0 & 0 & 0 & 0 & 0 & 0 & 0 & 0 \\
\hline
\end{tabular}


Table 15. Energy inputs to the electricity sector: Coal

\begin{tabular}{|l|r|r|r|r|r|r|r|r|r|r|r|r|}
\hline Thousand Short Tons & \multicolumn{1}{|c|}{$\mathbf{1 9 9 0}$} & $\mathbf{1 9 9 1}$ & $\mathbf{1 9 9 2}$ & $\mathbf{1 9 9 3}$ & $\mathbf{1 9 9 4}$ & $\mathbf{1 9 9 5}$ & $\mathbf{1 9 9 6}$ & $\mathbf{1 9 9 7}$ & $\mathbf{1 9 9 8}$ & $\mathbf{1 9 9 9}$ & $\mathbf{2 0 0 0}$ & $\mathbf{2 0 0 1}$ \\
\hline Electric Sector & $\mathbf{1 , 2 5 1}$ & $\mathbf{1 , 2 5 3}$ & $\mathbf{1 , 5 1 3}$ & $\mathbf{1 , 5 8 0}$ & $\mathbf{1 , 5 0 7}$ & $\mathbf{1 , 3 2 5}$ & $\mathbf{1 , 1 0 5}$ & $\mathbf{1 , 0 3 0}$ & $\mathbf{9 6 5}$ & $\mathbf{1 , 0 1 8}$ & $\mathbf{1 , 0 2 7}$ & $\mathbf{9 7 2}$ \\
CHP, Commercial Power & 0 & 0 & 0 & 0 & 0 & 0 & 0 & 0 & 0 & 0 & 0 & 0 \\
CHP, Electric Power & 759 & 992 & 1,052 & 1,164 & 1,021 & 970 & 782 & 767 & 826 & 873 & 879 & 819 \\
CHP, Industrial Power & 402 & 150 & 348 & 296 & 381 & 355 & 323 & 263 & 139 & 145 & 148 & 153 \\
Electric Generators, Utilities & 0 & 0 & 0 & 0 & 0 & 0 & 0 & 0 & 0 & 0 & 0 & 0 \\
Electric Generators, IPP & 90 & 111 & 113 & 120 & 105 & 0 & 0 & 0 & 0 & 0 & 0 & 0 \\
Non-specified & 0 & 0 & 0 & 0 & 0 & 0 & 0 & 0 & 0 & 0 & 0 & 0 \\
\hline Trillion Btu & $\mathbf{1 9 9 0}$ & $\mathbf{1 9 9 1}$ & $\mathbf{1 9 9 2}$ & $\mathbf{1 9 9 3}$ & $\mathbf{1 9 9 4}$ & $\mathbf{1 9 9 5}$ & $\mathbf{1 9 9 6}$ & $\mathbf{1 9 9 7}$ & $\mathbf{1 9 9 8}$ & $\mathbf{1 9 9 9}$ & $\mathbf{2 0 0 0}$ & $\mathbf{2 0 0 1}$ \\
\hline Electric Sector & $-\mathbf{2 5}$ & $-\mathbf{2 7}$ & $-\mathbf{3 3}$ & $-\mathbf{3 2}$ & $-\mathbf{3 3}$ & $\mathbf{- 2 9}$ & $\mathbf{- 2 6}$ & $\mathbf{- 2 3}$ & $\mathbf{- 2 1}$ & $\mathbf{- 2 4}$ & $\mathbf{- 2 4}$ & $\mathbf{- 2 3}$ \\
CHP, Commercial Power & 0 & 0 & 0 & 0 & 0 & 0 & 0 & 0 & 0 & 0 & 0 & 0 \\
CHP, Electric Power & -15 & -21 & -23 & -24 & -23 & -21 & -18 & -17 & -18 & -20 & -21 & -19 \\
CHP, Industrial Power & -8 & -3 & -7 & -6 & -8 & -8 & -8 & -6 & -3 & -3 & -3 & -4 \\
Electric Generators, Utilities & 0 & 0 & 0 & 0 & 0 & 0 & 0 & 0 & 0 & 0 & 0 & 0 \\
Electric Generators, IPP & -2 & -2 & -2 & -2 & -2 & 0 & 0 & 0 & 0 & 0 & 0 & 0 \\
Non-specified & 0 & 0 & 0 & 0 & 0 & 0 & 0 & 0 & 0 & 0 & 0 & 0 \\
\hline
\end{tabular}

Table 16. Energy inputs to the electricity sector: Other

\begin{tabular}{|l|r|r|r|r|r|r|r|r|r|r|r|r|}
\hline Trillion Btu & $\mathbf{1 9 9 0}$ & \multicolumn{1}{|c|}{$\mathbf{1 9 9 1}$} & $\mathbf{1 9 9 2}$ & $\mathbf{1 9 9 3}$ & $\mathbf{1 9 9 4}$ & $\mathbf{1 9 9 5}$ & $\mathbf{1 9 9 6}$ & $\mathbf{1 9 9 7}$ & $\mathbf{1 9 9 8}$ & $\mathbf{1 9 9 9}$ & $\mathbf{2 0 0 0}$ & $\mathbf{2 0 0 1}$ \\
\hline Electric Sector & $\mathbf{- 9 9 9}$ & $\mathbf{- 9 9 3}$ & $\mathbf{- 1 , 0 3 5}$ & $\mathbf{- 1 , 0 6 3}$ & $\mathbf{- 9 9 1}$ & $\mathbf{- 9 4 7}$ & $\mathbf{- 9 9 8}$ & $\mathbf{- 9 9 9}$ & $\mathbf{- 1 , 0 6 0}$ & $\mathbf{- 1 , 0 2 1}$ & $\mathbf{- 1 , 0 1 6}$ & $\mathbf{- 9 3 7}$ \\
CHP, Commercial Power & 0 & 0 & 0 & 0 & 0 & 0 & 0 & 0 & 0 & 0 & 0 & 0 \\
CHP, Electric Power & 0 & 0 & 0 & 0 & 0 & 0 & 0 & 0 & 0 & 0 & 0 & 0 \\
CHP, Industrial Power & 0 & 0 & 0 & 0 & 0 & 0 & 0 & 0 & 0 & 0 & 0 & 0 \\
Electric Generators, Utilities & -419 & -398 & -430 & -457 & -427 & -475 & -503 & -451 & -524 & -478 & -493 & -427 \\
Electric Generators, IPP & -3 & -4 & -3 & -9 & -4 & -11 & -10 & -8 & -7 & -5 & -4 & -2 \\
Non-specified & -576 & -591 & -602 & -598 & -561 & -462 & -486 & -540 & -529 & -538 & -519 & -507 \\
\hline
\end{tabular}

\subsubsection{Data Sources and Data Issues}

Data on fuel consumption by provider type are from the EIA's Electric Power Annual (U.S. EIA, 2003b). The EIA collects the information through questionnaires EIA-906 for electric power plants and EIA-920 for CHP facilities. ${ }^{12}$ Combined heat and power facilities are required to report only the fuel used to generate electricity that is either consumed onsite or sold. The quantity of fuel used to generate heat or steam for industrial or commercial purposes is not included and is therefore shown as part of end use consumption in the appropriate sector. This reporting method implies that CHP fuel consumption for electricity production either sold or consumed on site is accounted for in the transformation sector rather than in the end-use consumption sector. Only the final electricity consumption is reported in the end-use sectors. One can argue that the quantity of fuel used by CHP to produce the electricity consumed on site should be reported in the industry or service sector. However, the purpose of a balance is to show the transformation of energy carriers and the consumption of energy in its final form. Thus, all energy losses occurring in the transformation of one form of energy to another are shown in the transformation sector. In terms of $\mathrm{CO}_{2}$ emissions, the IPCC

${ }^{12}$ EIA data include only electric power plants or CHP facilities with capacity higher than $1 \mathrm{MW}$, but the Commission does collect some data on all plants of $100 \mathrm{~kW}$ capacity or greater. Although there are over 200 plants in California in the $100 \mathrm{~kW}$ to $1 \mathrm{MW}$ range, their total capacity comprises well less than $1 \%$ of the State's total generating capacity (CEC, 2001). 
guidelines necessitate a reallocation of the fuel consumption to the manufacturing/service sectors (IPCC, 1996). Emissions from CHP are assigned to the end-use sector where they were generated, independently from the quantity sold to the grid.

\subsubsection{Output}

\subsubsection{Trends}

Table 17 presents the total in-state production of electricity as well as a disaggregation by type of primary energy input, including fossil-fuel sources, non-thermal sources, and nonfossil-fuel thermal sources. Fossil-fuel sources of electricity include: natural gas, petroleum products, and coal. Natural gas is the dominant fuel source used to produce electricity in the state and its importance grew over the 1990 to 2001 period, with especially large increases seen in the last two years. The use of both oil and coal for production of electricity has declined over the period. Combined electricity generation from these two sources dropped from $12 \%$ to $5 \%$ of the total fossil-fuel generated electricity. ${ }^{13}$ Because the inputs for nonthermal and non-fossil thermal are derived from the generation data shown in Table 17, the trends in generation mirror those discussed in Section 4.4.1 above. Figure 4 depicts the information shown below as an area graph.

Table 17. Electricity produced in California by type of primary energy input, 1990 to 2001 (GWh)

\begin{tabular}{|c|c|c|c|c|c|c|c|c|c|c|c|c|}
\hline & 1990 & 1991 & 1992 & 1993 & 1994 & 1995 & 1996 & 1997 & 1998 & 1999 & 2000 & 2001 \\
\hline \multicolumn{13}{|l|}{ Fossil-fuel } \\
\hline Natural Gas & 74,168 & 74,006 & 88,705 & 79,644 & 94,432 & 72,579 & 64,414 & 71,002 & 75,132 & 85,099 & 103,236 & 111,932 \\
\hline Petroleum Products & 7,621 & 3,949 & 4,663 & 6,699 & 6,370 & 4,886 & 6,050 & 5,076 & 5,290 & 4,556 & 5,527 & 4,185 \\
\hline Coal & 2,638 & 2,632 & 3,300 & 3,130 & 3,272 & 2,787 & 2,529 & 2,332 & 2,159 & 2,296 & 2,364 & 2,233 \\
\hline \multicolumn{13}{|l|}{ Non-thermal } \\
\hline Hydro & 24,779 & 22,056 & 20,162 & 40,775 & 23,947 & 50,540 & 46,946 & 42,068 & 50,757 & 40,351 & 39,272 & 25,192 \\
\hline Wind & 3,031 & 3,008 & 2,893 & 3,064 & 3,421 & 3,118 & 3,253 & 2,185 & 2,720 & 3,230 & 3,518 & 3,500 \\
\hline Solar & 665 & 782 & 749 & 900 & 827 & 828 & 906 & 896 & 856 & 495 & 493 & 542 \\
\hline Other Generation & 0 & 5 & 10 & 11 & 14 & 16 & 28 & 22 & 20 & 23 & 22 & 17 \\
\hline \multicolumn{13}{|l|}{ Non-fossil thermal } \\
\hline Nuclear & 32,693 & 31,542 & 35,244 & 31,581 & 33,752 & 30,246 & 34,097 & 30,512 & 34,594 & 33,372 & 35,176 & 33,220 \\
\hline Geothermal & 13,978 & 14,236 & 14,523 & 14,468 & 13,216 & 10,979 & 11,659 & 13,359 & 13,169 & 13,046 & 12,308 & 12,181 \\
\hline Wood & 4,058 & 4,184 & 4,019 & 3,719 & 4,166 & 2,739 & 3,072 & 3,087 & 2,779 & 3,470 & 3,574 & 3,324 \\
\hline Landfill \& MSW & 1,606 & 1,586 & 1,620 & 1,745 & 1,787 & 1,778 & 1,649 & 1,731 & 1,637 & 1,706 & 1,938 & 1,861 \\
\hline Other Biomass & 548 & 961 & 1,266 & 1,253 & 987 & 968 & 661 & 527 & 487 & 676 & 673 & 410 \\
\hline Total & 165,785 & 158,947 & 177,154 & 186,990 & 186,191 & 181,464 & 175,263 & 172,797 & 189,600 & 188,320 & 208,100 & 198,596 \\
\hline
\end{tabular}

\footnotetext{
${ }^{13}$ Generation efficiencies for each fuel can be calculated by dividing the total Btu inputs from Tables 13 through 15 by the corresponding outputs in Table 17. These figures need to be multiplied by 1,000 to arrive at Btu/kWh, the unit in which heat rates are commonly reported.
} 


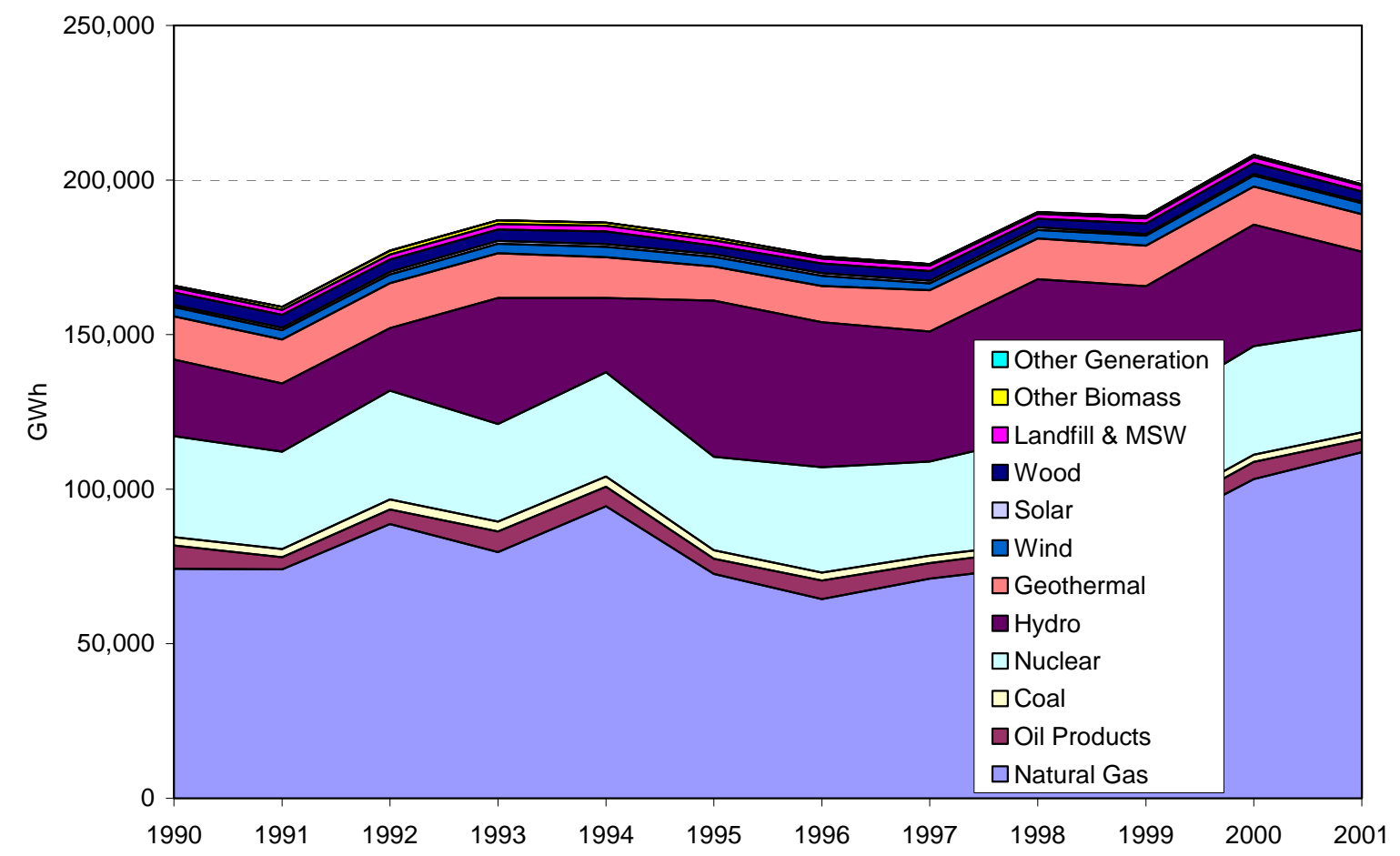

Source: EIA Electric Power Annual and Renewable Energy Annual, various years

\section{Figure 4. Electricity produced in California by type of primary energy input, 1990 to 2001}

\subsubsection{Data Sources and Issues}

The U.S. Energy Information Administration data on electricity generation for California are used for the CALEB database for two main reasons. First, the EIA's Electric Energy Annual has a strict state boundary definition, which excludes generation by out-of-state plants owned by in-state utilities, unlike the Energy Commission data. Secondly, data from the EIA's Electric Energy Annual are detailed by type of providers (e.g., CHP industrial, IPP), and it also provides data on fossil-fuel inputs by type of provider. Data on production of primary electricity from renewables are taken from the EIA's Renewable Energy Annual (U.S. EIA, various years). This source is used primarily because it disaggregates the breakout of energy types to a higher degree than either the Electric Power Annual or the Energy Commission's own electricity generation file (U.S.EIA, 2003b; CEC, 2003a).

\subsection{Oil Refineries}

The "oil refineries" flow in the transformation phase of the energy balance shows the crude oil (and other imported additives and feedstocks) used as inputs as negative numbers. The petroleum products resulting from the transformation process are shown as positive numbers. 


\subsubsection{Trends}

Table 18 provides data on the transformation phase for oil refineries in California. Crude oil inputs in refineries dropped from 694 million barrels (4,026 TBtu) in 1990 to 637 million barrels (3,697 TBtu) in 2001.

Ethanol is produced from the fermentation of biomass and can be used as an additive to motor gasoline. In the energy balance, it is accounted as an input to the refineries under the product category biomass. This distinction is particularly important when accounting for $\mathrm{CO}_{2}$ (see Section 8.4.2) because $\mathrm{CO}_{\mathrm{s}}$ emissions from biomass are not included in inventories of GHG emissions (IPCC, 1996) ${ }^{14}$ Motor gasoline is considered as a finished product issued from the refinery process and it includes blending components. As a result of the 1999 Governor's Executive Order directing the phaseout of MTBE, blending ethanol with motor gasoline is expected to grow dramatically in California in the near future.

\subsubsection{Data Sources and Data Issues}

Because the numerous types of petroleum products are produced from crude oil, there are several data sources that have been used to construct the energy statistics. First, crude intake into California refineries was taken from aggregated numbers from the PIIRA database provided by the Energy Commission (CEC 2003b). Another Energy Commission data set (CEC 2003c) provides alternate figures for crude oil receipts by source. Those figures tend to be from 1\% to 3\% higher than the figures reported in the intake and capacity report.

Detailed data on additives and feedstocks-as well as for specific petroleum products for 1995 through 2001-are provided by the Energy Commission based on the EIA report 810 submissions (CEC, 2004g). Due to the complexity of the refining industry, some products may be produced and reported as output and then later used as an input to another product. In order to avoid double counting, the research team subtracted the reported outputs from inputs, so that only net inputs are shown. ${ }^{15}$

\footnotetext{
${ }^{14}$ Emissions from the production of the biomass used for fuel may be included in inventories if net emissions occur due to land use change.

${ }^{15}$ These net inputs should theoretically be equivalent to imported feedstocks, blendstocks, and other additives, but there are some statistical differences.
} 
Table 18. Oil refinery transformation

\begin{tabular}{|c|c|c|c|c|c|c|c|c|c|c|c|c|}
\hline Inputs (Million Barrels) & 1990 & 1991 & 1992 & 1993 & 1994 & 1995 & 1996 & 1997 & 1998 & 1999 & 2000 & 2001 \\
\hline Crude & 694 & 684 & 660 & 670 & 660 & 634 & 638 & 634 & 634 & 614 & 635 & 637 \\
\hline Additives & & & & & & 30 & 43 & 47 & 48 & 47 & 48 & 44 \\
\hline Feedstocks & & & & & & 22 & 15 & 17 & 20 & 27 & 26 & 22 \\
\hline Ethanol & 1 & 1 & 0 & 1 & 1 & 3 & 2 & 2 & 2 & 1 & 2 & N/A \\
\hline Outputs (Million Barrels) & 1990 & 1991 & 1992 & 1993 & 1994 & 1995 & 1996 & 1997 & 1998 & 1999 & 2000 & 2000 \\
\hline Motor Gas & & & & & & 357 & 364 & 372 & 385 & 375 & 394 & 387 \\
\hline Still Gas & & & & & & 41 & 43 & 43 & 42 & 40 & 41 & 43 \\
\hline Jet Fuel & & & & & & 90 & 105 & 100 & 95 & 82 & 89 & 88 \\
\hline Distillate Fuel & & & & & & 102 & 98 & 101 & 100 & 105 & 106 & 111 \\
\hline Residual Fuel & & & & & & 44 & 41 & 32 & 31 & 37 & 27 & 26 \\
\hline Petroleum Coke & & & & & & 47 & 48 & 49 & 52 & 48 & 52 & 49 \\
\hline & & & & & & 0 & 20 & 19 & 18 & 16 & 21 & 17 \\
\hline Others & & & & & & 24 & 23 & 24 & 23 & 25 & 31 & 26 \\
\hline Total Petroleum Products & & & & & & 679 & 718 & 716 & 723 & 704 & 343 & 720 \\
\hline Inputs (TBtu) & 1990 & 1991 & 1992 & 1993 & 1994 & 1995 & 1996 & 1997 & 1998 & 1999 & 2000 & 2001 \\
\hline Crude & $-4,026$ & $-3,970$ & $-3,827$ & $-3,887$ & $-3,827$ & $-3,678$ & $-3,701$ & $-3,677$ & $-3,679$ & $-3,563$ & $-3,684$ & $-3,697$ \\
\hline Additives & & & & & & -95 & -137 & -149 & -152 & -151 & -154 & -139 \\
\hline Feedstocks & & & & & & -119 & -79 & -85 & -103 & -149 & -146 & -116 \\
\hline Ethanol & -4 & -5 & -1 & -2 & -3 & -9 & -8 & -8 & -6 & -5 & -6 & N/A \\
\hline Total Inputs & $-4,030$ & $-3,975$ & $-3,828$ & $-3,889$ & $-3,830$ & $-3,901$ & $-3,925$ & $-3,919$ & $-3,940$ & $-3,868$ & $-3,990$ & N/A \\
\hline Outp & 1990 & 1991 & 1992 & 1993 & 1994 & 1995 & 1996 & 1997 & 1998 & 1999 & 2000 & 2001 \\
\hline & & & & & & 1,828 & 1,851 & 1,891 & 1,957 & 1,906 & 2,004 & 1,965 \\
\hline Gas & & & & & & 244 & 260 & 259 & 254 & 241 & 248 & 259 \\
\hline Jet Fuel & & & & & & 509 & 593 & 567 & 537 & 464 & 507 & 498 \\
\hline Distillate Fuel & & & & & & 594 & 573 & 586 & 584 & 610 & 618 & 648 \\
\hline Residual Fuel & & & & & & 274 & 255 & 204 & 195 & 233 & 172 & 160 \\
\hline Petroleum Coke & & & & & & 281 & 288 & 295 & 311 & 292 & 310 & 293 \\
\hline LPG & & & & & & 0 & 71 & 67 & 65 & 59 & 75 & 60 \\
\hline Others & & & & & & 177 & 171 & 174 & 168 & 185 & 194 & 191 \\
\hline Total Petroleum Products & & & & & & 3,906 & 4,061 & 4,043 & 4,071 & 3,989 & 4,128 & 4,075 \\
\hline
\end{tabular}

\subsection{Energy Sector: Own Use}

This section provides information on the consumption of energy needed to operate refineries or power plants, as well as the energy required to extract energy resources. This may consist of purchased electricity or natural gas, or energy recovered on site. For example, a significant portion of the crude oil that enters a refinery is ultimately used for process energy. This consists largely of the less-marketable fuels that are derived from crude oil such as still gas and petroleum coke. This category also includes the energy used for oil and natural gas extraction and energy used for coal mining. This "own use" data answers the question "How much energy does it take to produce energy?" In California, major transformation sector consumers of energy include natural gas power plants, ${ }^{16}$ oil refineries, and the energy used for oil and gas extraction.

\footnotetext{
${ }^{16}$ In the IEA format gross (or total) generation is reported along with the power plants' own use. However, generation data in the United States are generally reported in net figures (the difference of gross generation and own use), because data on power plant's own use is often considered confidential. Although net generation data
} 


\subsubsection{Trends}

Table 19 and Table 20 show the energy consumed within refineries and for oil and gas extraction in California, respectively, for 1990 to 2001. Refineries consume a combination of natural gas, petroleum products, and electricity in order to produce petroleum products. Consumption of natural gas grew the most over the period, followed by a slight increase in the use of petroleum products. Electricity consumption peaked in 1996 at 7,534 GWh and fell steadily to 5,937 GWh in 2001.

Oil and gas extraction shows the energy used for the pumping and processing of crude oil, as well as extraction of natural gas and natural gas liquids (NGLs). In California, these figures tend to be exceptionally high, due to the large amount of thermally enhanced oil recovery (TEOR), which uses large amounts of natural gas to heat crude oil to render it less viscous. Natural gas use for oil and gas extraction grew from 190,901 million cubic feet in 1990 to 295,171 million cubic feet in 2001. Electricity use declined from a peak of 4,418 GWh in 1997 to 3,730 GWh in 2001.

Table 19. Refineries' own energy use

\begin{tabular}{|c|c|c|c|c|c|c|c|c|c|c|c|c|}
\hline Physical Units & 1990 & 1991 & 1992 & 1993 & 1994 & 1995 & 1996 & 1997 & 1998 & 1999 & 2000 & 2001 \\
\hline Natural Gas (Mcf) & 80,484 & 75,905 & 68,803 & 67,176 & 58,389 & 79,884 & 102,837 & 109,042 & 98,676 & 92,978 & 107,936 & 94,386 \\
\hline Still Gas (kbbl) & 41,154 & 40,997 & 39,625 & 49,102 & 49,680 & 34,765 & 40,188 & 39,748 & 39,161 & 35,819 & 34,410 & 38,798 \\
\hline Petroleum Coke (kbbl) & 11,103 & 12,190 & 12,501 & 12,576 & 12,353 & 12,206 & 15,597 & 14,922 & 13,247 & 11,416 & 16,041 & 16,826 \\
\hline LPG (kbbl) & 3,527 & 4,080 & 6,915 & 4,676 & 5,084 & 3,508 & 2,495 & 2,032 & 1,274 & 1,123 & 2,073 & 2,946 \\
\hline Electricity (GWh) & 7,302 & 7,426 & 7,111 & 7,249 & 7,571 & 7,464 & 7,534 & 7,293 & 6,685 & 6,490 & 6,230 & 5,937 \\
\hline TBtu & 1990 & 1991 & 1992 & 1993 & 1994 & 1995 & 1996 & 1997 & 1998 & 1999 & 2000 & 2001 \\
\hline Natural Gas & -83 & -78 & -71 & -70 & -60 & -81 & -106 & -111 & -104 & -95 & -106 & -92 \\
\hline Petroleum Products & -327 & -335 & -339 & -388 & -392 & -295 & -344 & -336 & -320 & -288 & -311 & -345 \\
\hline Electricity & -25 & -25 & -24 & -25 & -26 & -25 & -26 & -25 & -23 & -22 & -21 & -20 \\
\hline
\end{tabular}

Table 20. Oil and gas extraction

\begin{tabular}{|c|c|c|c|c|c|c|c|c|c|c|c|c|}
\hline Physical Units & 1990 & 1991 & 1992 & 1993 & 1994 & 1995 & 1996 & 1997 & 1998 & 1999 & 2000 & 2001 \\
\hline Natural Gas (Mcf) & 190,901 & 205,934 & 173,322 & 160,801 & 155,520 & 201,619 & 205,222 & 282,315 & 306,468 & 276,551 & 291,092 & 295,171 \\
\hline Electricity (GWh) & 4,269 & 4,413 & 4,309 & 4,341 & 4,290 & 4,171 & 4,223 & 4,418 & 4,288 & 3,818 & 3,845 & 3,730 \\
\hline TBtu & 1990 & 1991 & 1992 & 1993 & 1994 & 1995 & 1996 & 1997 & 1998 & 1999 & 2000 & 2001 \\
\hline Natural Gas & -197 & -211 & -178 & -167 & -159 & -204 & -212 & -287 & -322 & -281 & -285 & -289 \\
\hline Electricity & -15 & -15 & -15 & -15 & -15 & -14 & -14 & -15 & -15 & -13 & -13 & -13 \\
\hline
\end{tabular}

\subsubsection{Data Sources and Data Issues}

Figures on consumption of electricity and natural gas for petroleum refining and oil and gas extraction were taken from the Energy Commission databases on utility deliveries (CEC, 2004a; CEC, 2004b). Data for refineries' own use of petroleum products is from an Energy Commission data set aggregated from the monthly refinery reporting forms (Helmowski, 2004). The data from this series was also used to adjust the total "Industry" consumption figures in SEDS, because SEDS includes petroleum refining as part of industry.

are used for CALEB, this does not affect the energy balance because the amount of electricity available to endusers and other energy sector facilities remains the same. 


\subsection{Distribution Losses}

\subsubsection{Trends}

Electricity distribution losses are losses of electricity in the transmission and distribution (T\&D) networks. Table 21 shows that in California these losses have not fluctuated significantly over the 1990 to 2001 period.

Table 21. Estimated distribution losses

\begin{tabular}{|l|l|l|l|l|l|l|l|l|l|l|l|l|}
\hline $\boldsymbol{G W h}$ & $\mathbf{1 9 9 0}$ & $\mathbf{1 9 9 1}$ & $\mathbf{1 9 9 2}$ & $\mathbf{1 9 9 3}$ & $\mathbf{1 9 9 4}$ & $\mathbf{1 9 9 5}$ & $\mathbf{1 9 9 6}$ & $\mathbf{1 9 9 7}$ & $\mathbf{1 9 9 8}$ & $\mathbf{1 9 9 9}$ & $\mathbf{2 0 0 0}$ & $\mathbf{2 0 0 1}$ \\
\hline Electricity & 20,188 & 19,387 & 19,643 & 19,362 & 20,537 & 20,509 & 20,290 & 20,406 & 22,113 & 22,064 & 22,440 & 21,209 \\
\hline
\end{tabular}

\subsubsection{Data Sources and Data Issues}

Because actual data on losses are difficult to obtain, losses are currently estimated by induction using an assumption of $8 \%$ losses of electricity delivered to the grid, based on a figure taken from Brown and Koomey (2003), which was based on reported California loads and losses (CEC, 2000). Thus, final consumption is divided by 0.92 and subtracted from the result, in order to approximate the electricity lost.

In order to validate this figure as a reasonable estimate, Berkeley Lab calculated a weighted average using individual utility T\&D loss data from the 1994 Electricity Report (CEC, 1995). This calculation resulted in average T\&D losses of $8.8 \%$ for that year. Berkeley Lab is investigating other sources of data on annual T\&D losses.

Firm data on natural gas distribution losses are difficult to find. In the current version of CALEB, the research team has not attempted to incorporate any estimates of these losses into the balances. The EIA furnishes "unaccounted for" natural gas in the Natural Gas Annual (U.S. EIA, various years). The figures generally hover around $1 \%$ of total supply from year to year. However, the IPCC cautions against using unaccounted for natural gas as an estimate for distribution losses, because factors other than actual fugitive emissions-such as meter inaccuracies - often account for the majority of gas reported in this category (IPCC, 1996). Estimates by the U.S. EPA suggest that fugitive emissions from transmission, storage, and distribution of natural gas constitute less than $1 \%$ of total natural gas consumed, but because of the greater global warming potential of methane, these emissions would increase GHG emissions attributable to natural gas combustion by nearly 6\% (U.S. EPA, 2004b). 


\section{End-Use Consumption}

\subsection{Energy End-Use Consumption Sectors}

Energy is consumed for many different purposes, and it can be useful to track not only changes in total state energy consumption, but also to observe trends in end-use consumption within various end-use sectors. For the purpose of the CALEB database, energy consumption data have been categorized into four principal end-use sectors: (1) industry, (2) transportation, (3) services, and (4) residences.

\subsubsection{Industry (Agriculture, Mining, Manufacturing)}

The industry sector documents all energy consumed by manufacturing industries (e.g., aluminum, pulp and paper, electronics) and non-manufacturing industries (e.g., agriculture, forestry, construction, and mining for non-energy minerals and metals). In order to avoid double counting of energy consumed for CHP, the reported energy consumed for CHP in the Transformation Sector was deducted from industry totals. Additionally, because separate figures were available for the petroleum refining industry, these were deducted from the SEDS “industry” totals.

\subsubsection{Transportation}

The transportation sector includes all energy consumption by vehicles. Transportation includes energy used both for passenger travel and freight, including that used by railroads, trucks, automobiles, taxis, buses, other forms of mass transit, water transportation, air travel (intrastate, interstate, and international), and natural gas pipelines.

Energy used by buildings associated with commercial transportation (e.g., terminals, airports, garages, or administrative activities) appears in the "services" sector.

\subsubsection{Services}

The services sector (sometimes called the commercial sector) consists of a broad assortment of activities. Essentially, it represents the energy consumed by all buildings that are not either residential or industrial in nature. For example, this sector includes buildings used for activities as diverse as hotels, restaurants, warehouses, retail, government, education, incarceration, entertainment, and religious assembly. Communication services (e.g., the U.S. Postal Service and telephone and radio services) along with utilities (e.g., electric power, sewer, water, street lights) are included in this sector.

\subsubsection{Residential}

The residential sector consists of all buildings used primarily for housing. There is no disaggregation in this sector. In other words, the data are not differentiated by various types of housing, such as single family or multifamily. 


\subsection{Natural Gas}

\subsubsection{Trends}

Table 22 shows natural gas consumption data from 1990 to 2001 for the various end-use sectors. Overall, natural gas consumption for the end-use sectors remained relatively stable over the period, experiencing a slight peak in 1999. Within the end-use sectors, residential buildings consumed the largest amount of natural gas during this period, followed by industry and services, respectively. The surge in consumption by the transport sector in 1997 is due to the fact that the data series on natural gas consumption by natural gas pipelines began that year.

Table 22. Natural gas consumption by end-use sector

\begin{tabular}{|c|c|c|c|c|c|c|c|c|c|c|c|c|}
\hline Billion Cubic Feet & 1990 & 1991 & 1992 & 1993 & 1994 & 1995 & 1996 & 1997 & 1998 & 1999 & 2000 & 2001 \\
\hline End Use Sectors & & & & & & & & & & & & \\
\hline Agriculture & 10 & 9 & 9 & 8 & 11 & 10 & 11 & 12 & 13 & 16 & 18 & 13 \\
\hline Mining & 1 & 1 & 1 & 1 & 1 & 6 & 6 & 6 & 7 & 6 & 6 & 6 \\
\hline Manufacturing & 228 & 216 & 194 & 191 & 205 & 208 & 211 & 208 & 199 & 209 & 199 & 216 \\
\hline Used for Heat in $\mathrm{CHP}^{\mathrm{a}}$ & & & & & & & & & 29 & 15 & 37 & \\
\hline Transport & 3 & 3 & 3 & 3 & 3 & 3 & 3 & 25 & 12 & 12 & 13 & 14 \\
\hline Services & 193 & 186 & 171 & 170 & 184 & 170 & 170 & 179 & 195 & 209 & 208 & 193 \\
\hline Used for Heat in CHP & & & & & & & & & 77 & 160 & 98 & \\
\hline Residential & 506 & 513 & 490 & 496 & 519 & 475 & 470 & 473 & 527 & 566 & 541 & 522 \\
\hline Non-specified (Other) & 20 & 11 & 9 & 10 & 12 & 10 & 9 & 7 & -2 & 11 & 15 & 10 \\
\hline Total & 960 & 939 & 877 & 878 & 935 & 881 & 880 & 911 & 1,047 & 1,205 & 1,135 & 973 \\
\hline Trillion Btu & 1990 & 1991 & 1992 & 1993 & 1994 & 1995 & 1996 & 1997 & 1998 & 1999 & 2000 & 2001 \\
\hline End Use Sectors & & & & & & & & & & & & \\
\hline Agriculture & 10 & 9 & 9 & 8 & 12 & 10 & 11 & 13 & 14 & 16 & 18 & 12 \\
\hline Mining & 1 & 1 & 1 & 1 & 1 & 6 & 6 & 6 & 8 & 6 & 6 & 6 \\
\hline Manufacturing & 235 & 222 & 200 & 198 & 210 & 211 & 218 & 212 & 210 & 213 & 195 & 211 \\
\hline Used for Heat in CHP & & & & & & & & & 30 & 15 & 36 & \\
\hline Transport & 3 & 3 & 3 & 3 & 3 & 3 & 3 & 26 & 13 & 13 & 13 & 14 \\
\hline Services & 200 & 191 & 176 & 177 & 188 & 173 & 176 & 183 & 194 & 213 & 203 & 188 \\
\hline Used for Heat in CHP & & & & & & & & & 81 & 163 & 96 & \\
\hline Residential & 522 & 527 & 504 & 514 & 530 & 481 & 485 & 481 & 554 & 576 & 529 & 510 \\
\hline Non-specified (Other) & 20 & 11 & 9 & 11 & 12 & 10 & 9 & 8 & -2 & 11 & 14 & 10 \\
\hline Total & 991 & 964 & 901 & 911 & 955 & 893 & 909 & 928 & 1,101 & 1,226 & 1,110 & 951 \\
\hline
\end{tabular}

${ }^{a}$ Data only permit estimation of the fuel used to produce heat from CHP units for 1998 to 2000. Thus, there is a break in series total for these years.

\subsubsection{Data Sources and Data Issues}

The Commission maintains data on natural gas consumption at three different levels of aggregation (CEC, 2004b). The most detailed data are at the 3- to 4-digit Standard Industrial Classification (SIC) code level. ${ }^{17}$ For CALEB, the data at the intermediate level of disaggregation was chosen as the primary data source. This series provides consumption data

\footnotetext{
${ }^{17}$ Conversion to the North American Industry Classification System (NAICS) codes begins with year 2002 data.
} 
on 38 industries and 34 commercial, public sector, and residential categories. This data set was preferred over using more aggregated sources such as the EIA's SEDS, due to the richness of detail it contains. The data from the Energy Commission are reported directly by the distributing utilities, and thus are assumed to be reliable. As described above, these values do not include the shares of natural gas used for CHP-generated electricity, because these values are reported in the "Transformation Sector" category.

A separate Energy Commission data series reports all natural gas consumed for CHP (CEC, 2004h). The natural gas used for the electricity output of CHP is already reported in the transformation sector using an EIA data series. Thus, the Energy Commission data cannot be simply added into the end-use consumption series, or the portion used for electricity will be double counted. Because the EIA data set only provides data aggregated at the sectoral level (e.g., industrial, commercial), the input for electricity cannot be simply deducted from the disaggregated Energy Commission data. An additional concern with the Energy Commission CHP data is that the total consumption figures given in that file are less than the natural gas consumed only for the electricity output from CHP, as reported by EIA. Berkeley Lab is investigating this discrepancy.

In order to determine the quantity of natural gas consumed for the useful thermal output of CHP systems, it was necessary to go to the original plant-specific data used by EIA to construct the data series given in the Electric Power Annual publications. Specifically, figures from the Form EIA-860B provide data on generation, fuel consumption, and useful thermal output by plant for the years 1998 through 2000 (U.S. EIA, 2004f). The plant-specific numbers for useful thermal output are divided by 0.8 to replicate the EIA methodology of assuming an $80 \%$ conversion efficiency of fuel energy to useful thermal output from CHP systems and allocating the remainder of total fuel input to electricity production. Because many plants consume more than one type of fuel, the plant's share of fuel consumed for heat as a percentage of total fuel consumption is used to apportion the individual fuels into electricity and heat shares. The record for each plant includes its primary NAICS code, which was used to map the natural gas combusted for thermal output to the corresponding CALEB categories.

From 2001 on, the Form EIA-860B was superseded by Forms EIA-860 and EIA-906. Fuel consumption and generation data are provided in EIA-906 (U.S. EIA, 2004g). The EIA-906 does not provide data on useful thermal output per se, but it does report both total fuel consumption and fuel consumed for electricity generation. The difference between the two provides the fuel consumed for heat output. As explained in the layout document embedded in the EIA-906 spreadsheets, whenever an omission or inconsistency in the data results in all or part of a facility's data being imputed by the EIA, its generation and fuel consumption are not reported in a plant-specific record. Instead, these figures are aggregated by state and fuel type. This change in reporting format necessitates that allocation of fuel consumed for useful heat by end-user category be estimated, possibly based on historic data. ${ }^{18}$ In addition, since 2001 was a transition year, the format of the EAI-906 form was not revised to include either data on

\footnotetext{
${ }^{18}$ As an example of the quantity of fuel consumed for useful heat that can no longer be directly attributed to specific plants, Berkeley Lab estimates that the aggregated state-level category accounts for nearly a third of natural gas consumed for useful heat in CHP systems in California in 2002.
} 
useful thermal output or shares of fuel consumed for electricity. This means that there is no way to accurately estimate the natural gas consumed for heat from the 2001 data. In order to prevent a gap in the data series, Berkeley Lab will estimate figures for 2001 based on the electricity output of the CHP plants and their average ratios of heat to power production.

\subsection{Petroleum Products}

\subsubsection{Trends}

Consumption of petroleum products by the end-use sectors remained relatively stable overall during the period 1990 to 2001, but among the individual sectors, industry's use of petroleum products decreased significantly while use in the transportation sector grew. Use of motor gasoline $^{19}$ increased substantially over this period, with consumption in 2000 more than $10 \%$ higher than in 1990 (Table 23). Consumption of distillate fuel oil fell sharply in the early 1990s, but in more recent years it has increased to previous levels (Table 24).

Table 23. Motor gasoline consumption by end-use sector

\begin{tabular}{|c|c|c|c|c|c|c|c|c|c|c|c|c|}
\hline $\begin{array}{l}\text { Thousand } \\
\text { Barrels }\end{array}$ & 1990 & 1991 & 1992 & 1993 & 1994 & 1995 & 1996 & 1997 & 1998 & 1999 & 2000 & 2001 \\
\hline Industry & 3,163 & 3,271 & 3,297 & 2,664 & 2,758 & 2,849 & 2,741 & 2,910 & 3,263 & 1,922 & 1,992 & 4,581 \\
\hline Transport & 300,893 & 293,780 & 310,861 & 305,800 & 304,669 & 310,379 & 315,285 & 319,727 & 326,430 & 335,633 & 340,681 & 347,202 \\
\hline Services & 1,928 & 1,647 & 1,485 & 262 & 226 & 236 & 231 & 233 & 250 & 236 & 240 & 248 \\
\hline Total & 305,983 & 298,698 & \begin{tabular}{|l|}
315,643 \\
\end{tabular} & 308,726 & 307,653 & 313,464 & 318,257 & 322,871 & 329,943 & \begin{tabular}{|l|}
337,791 \\
\end{tabular} & 342,913 & \begin{tabular}{|l|}
352,031 \\
\end{tabular} \\
\hline Trillion Btu & 1990 & 1991 & 1992 & 1993 & 1994 & 1995 & 1996 & 1997 & 1998 & 1999 & 2000 & 2001 \\
\hline Industry & 17 & 17 & 17 & 14 & 14 & 15 & 14 & 15 & 17 & 10 & 10 & 23 \\
\hline Transport & 1,580 & 1,542 & 1,632 & 1,605 & 1,600 & 1,629 & 1,616 & 1,625 & 1,659 & 1,706 & 1,731 & 1,764 \\
\hline Services & 10 & 9 & 8 & 1 & 1 & 1 & 1 & 1 & 1 & 1 & 1 & 1 \\
\hline Total & 1,606 & 1,568 & 1,657 & 1,621 & 1,615 & 1,646 & 1,631 & 1,641 & 1,677 & 1,717 & 1,743 & 1,789 \\
\hline
\end{tabular}

Table 24. Distillate fuel oil consumption by end-use sector

\begin{tabular}{|c|c|c|c|c|c|c|c|c|c|c|c|c|}
\hline $\begin{array}{l}\text { Thousand } \\
\text { Barrels }\end{array}$ & 1990 & 1991 & 1992 & 1993 & 1994 & 1995 & 1996 & 1997 & 1998 & 1999 & 2000 & 2001 \\
\hline Industry & 17,119 & 14,139 & 12,724 & 13,113 & 14,244 & 12,034 & 12,158 & 14,413 & 13,292 & 15,313 & 19,330 & 21,721 \\
\hline Transport & 54,443 & 53,990 & 53,930 & 49,473 & 56,273 & 58,486 & 58,780 & 63,625 & 64,190 & 66,669 & 71,764 & 70,303 \\
\hline Services & 4,224 & 4,472 & 2,347 & 2,450 & 2,433 & 3,327 & 2,649 & 2,577 & 2,779 & 2,899 & 3,250 & 2,879 \\
\hline Residential & 208 & 200 & 236 & 238 & 240 & 184 & 153 & 165 & 177 & 181 & 252 & 298 \\
\hline Total & 75,994 & 72,801 & 69,238 & 65,274 & 73,190 & 74,031 & 73,740 & 80,779 & 80,437 & 85,062 & 94,596 & 95,200 \\
\hline Trillion Btu & 1990 & 1991 & 1992 & 1993 & 1994 & 1995 & 1996 & 1997 & 1998 & 1999 & 2000 & 2001 \\
\hline Industry & 100 & 82 & 74 & 76 & 83 & 70 & 71 & 84 & 77 & 89 & 113 & 127 \\
\hline Transport & 317 & 314 & 314 & 288 & 328 & 341 & 342 & 371 & 374 & 388 & 418 & 410 \\
\hline Services & 25 & 26 & 14 & 14 & 14 & 19 & 15 & 15 & 16 & 17 & 19 & 17 \\
\hline Residential & 1 & 1 & 1 & 1 & 1 & 1 & 1 & 1 & 1 & 1 & 1 & 2 \\
\hline Total & 443 & 424 & 403 & 380 & 426 & 431 & 430 & 471 & 469 & 495 & 551 & 555 \\
\hline
\end{tabular}

\footnotetext{
${ }^{19}$ Consumption figures for motor gasoline include all additives and blending components, such as ethanol. For future versions of CALEB, the ethanol will be deducted from the motor gasoline figure before calculating bottom-up $\mathrm{CO}_{2}$ emissions.
} 
Table 25 shows that jet fuel consumption has remained relatively stable, growing only slightly between 1990 and 2001. Consumption of other petroleum products by industry dropped sharply after 1990, largely due to a corresponding drop in the SEDS "other petroleum products" category, as well as drops in the reported use of LPG and residual fuel oil (see Table 26). ${ }^{20}$ "Non-energy use" refers to the reported consumption of lubricants, asphalt, road oil, and part of the SEDS “other petroleum products.”

Table 25. Jet fuel consumption in transportation

\begin{tabular}{|c|c|c|c|c|c|c|c|c|c|c|c|c|}
\hline $\begin{array}{l}\text { Thousand } \\
\text { Barrels } \\
\end{array}$ & 1990 & 1991 & 1992 & 1993 & 1994 & 1995 & 1996 & 1997 & 1998 & 1999 & 2000 & 2001 \\
\hline Military & 5,125 & 4,863 & 4,681 & 4,819 & 5,335 & 5,146 & 5,604 & 5,570 & 5,691 & 5,328 & 5,562 & 5,250 \\
\hline Intrastate & 6,644 & 6,305 & 6,068 & 6,247 & 6,916 & 6,672 & 7,264 & 7,221 & 7,377 & 6,908 & 7,211 & 6,806 \\
\hline International & 35,823 & 33,995 & 32,721 & 33,685 & 37,290 & 35,973 & 39,169 & 38,932 & 39,778 & 37,245 & 38,878 & 36,695 \\
\hline Total & 94,907 & 90,064 & 86,688 & 89,244 & 98,793 & 95,305 & 103,773 & 103,144 & 105,385 & 98,673 & 103,001 & 97,216 \\
\hline Military & 29 & 28 & 27 & 27 & 30 & 29 & 32 & 32 & 32 & 30 & 32 & 30 \\
\hline Intrastate & 38 & 36 & 34 & 35 & 39 & 38 & 41 & 41 & 42 & 39 & 41 & 39 \\
\hline Interstate & 268 & 255 & 245 & 252 & 279 & 269 & 293 & 292 & 298 & 279 & 291 & 275 \\
\hline International & 203 & 193 & 186 & 191 & 211 & 204 & 222 & 221 & 226 & 211 & 220 & 208 \\
\hline Total & 538 & 511 & 492 & 506 & 560 & 540 & 588 & 585 & 598 & 559 & 584 & 551 \\
\hline
\end{tabular}

Table 26. Other petroleum products consumption by end-use sector

\begin{tabular}{|c|c|c|c|c|c|c|c|c|c|c|c|c|}
\hline $\begin{array}{l}\text { Thousand } \\
\text { Barrels }\end{array}$ & 1990 & 1991 & 1992 & 1993 & 1994 & 1995 & 1996 & 1997 & 1998 & 1999 & 2000 & 2001 \\
\hline Industry & 17,295 & 12,860 & 15,527 & 13,572 & 15,467 & 15,256 & 9,703 & 9,070 & 8,740 & 11,492 & 8,254 & 8,430 \\
\hline Transport & 4,596 & 3,957 & 3,216 & 2,949 & 3,563 & 3,700 & 3,391 & 2,395 & 2,355 & 2,764 & 4,118 & 4,289 \\
\hline Services & 2,019 & 2,078 & 928 & 924 & 904 & 886 & 751 & 664 & 1,176 & 1,077 & 64 & 65 \\
\hline Residential & 5,881 & 7,060 & 4,919 & 5,126 & 5,040 & 4,920 & 4,154 & 3,760 & 6,179 & 5,823 & 7,014 & 5,099 \\
\hline Non Energy Use & 23,494 & 21,838 & 21,515 & 20,517 & 20,044 & 19,683 & 19,422 & 18,672 & 23,563 & 28,073 & 26,492 & 26,080 \\
\hline Total & 53,285 & 47,793 & 46,105 & 43,088 & 45,018 & 44,445 & 37,421 & 34,561 & 42,013 & 49,229 & 45,942 & 43,963 \\
\hline Trillion Btu & 1990 & 1991 & 1992 & 1993 & 1994 & 1995 & 1996 & 1997 & 1998 & 1999 & 2000 & 2001 \\
\hline Industry & 76 & 56 & 67 & 61 & 70 & 71 & 42 & 40 & 39 & 50 & 38 & 17 \\
\hline Transport & 25 & 21 & 17 & 16 & 19 & 21 & 19 & 13 & 12 & 15 & 21 & 21 \\
\hline Services & 10 & 10 & 4 & 3 & 3 & 3 & 3 & 2 & 5 & 4 & 0 & 0 \\
\hline Residential & 22 & 26 & 18 & 19 & 18 & 18 & 15 & 14 & 23 & 21 & 26 & 2 \\
\hline Non Energy Use & 149 & 138 & 136 & 129 & 127 & 125 & 123 & 118 & 150 & 179 & 170 & 168 \\
\hline Total & 282 & 251 & 242 & 228 & 237 & 238 & 202 & 187 & 229 & 269 & 255 & 208 \\
\hline
\end{tabular}

\footnotetext{
${ }^{20}$ SEDS “Other Petroleum Products” includes crude oil, natural gas, petroleum feedstocks, plant condensate, pentanes plus, special naphthas, still gas, unfractionated stream, waxes, unfinished oils, motor and aviation gasoline blending components, and other miscellaneous products (U.S. EIA, 2004d). Table 26 also includes data on LPG, aviation gasoline, jet fuel, kerosene, residual fuel oil, petroleum coke, lubricants, asphalt, and road oil.
} 


\subsubsection{Data Sources and Data Issues}

Data for petroleum product consumption by end-use sector were taken largely from SEDS, because it provides a comprehensive set of data for ten categories of petroleum products (U.S. EIA, 2003a). Sales of residual and distillate fuels in the transportation sector in SEDS were corrected for the use of vessel bunkering with data from the EIA Fuel Oil and Kerosene Sales reports (Walzer, 2004).

As discussed in Section 4.2.2.3, this study assumed that 95\% of California's 2000 transportsector residual fuel consumption is allocated as international marine bunker fuel. For the remaining $5 \%$ of 2000 transport-sector residual fuel, the research team estimated that 3.5\% was used by interstate marine shipping activities and $1.5 \%$ was consumed for intrastate marine shipping activities. The estimates for interstate and intrastate residual fuel consumption were made using the "ship movement methodology" of the EEA (EEA, 2004). For intrastate shipping, Berkeley Lab assumed that all commodity shipments occurred between the Los Angeles and San Francisco, based on the observation that roughly 85\% of the tonnage shipped from California in 2000 was shipped from ports located in the Los Angeles and San Francisco areas (U.S. WCSC, 2000b).

In Section 4.2.2.3, Berkeley Lab estimated that 2.7\% of the transport-sector distillate fuel consumed in California in 2000 was attributable to international marine bunker fuel usage. It was assumed that $0.1 \%$ of total 2000 transport-sector distillate fuel consumption was for interstate shipping activities and that $0.05 \%$ was for intrastate consumption using the same interstate and intrastate breakdown that was used for residual fuel. According to IPCC guidelines, fuels consumed for international maritime shipping as well as international aviation should be excluded from national inventories (IPCC, 1996). However, in the IEA energy balance format, aviation fuels consumed for both international flights and domestic flights are reported as separate items in the "Transportation" category. The research team estimated the average percentage of California's 2000 jet fuel purchases that were consumed as bunker fuels for international, interstate, and intrastate travel using the EEA "aircraft movement methodology” of the EEA (EEA, 2004).

Following the EEA approach, the number of flights from California to domestic and foreign destinations in 2003 was determined using the U.S. Bureau of Transportation Statistics Air Carriers: T-100 Segment data series (U.S. BTS, 2004). The Air Carriers: T-100 Segment data provide the total number of one-way flights, aircraft type, destination airport, and total flight distance to the destination airport for all commercial flights originating from California airports in a given year. For each aircraft type, the average fuel intensity (kg fuel/kilometers $(\mathrm{km})$ ) was estimated using data from the EEA (EEA, 2004). To estimate the total jet fuel consumed by commercial flights from California airports to foreign airports in 2003, the average fuel intensity for each aircraft type was multiplied by the number of one-way flights and flight distance for each tabulated airport pair. Berkeley Lab employed a similar approach to estimate the total jet fuel consumed by interstate and intrastate commercial flights originating in California. Based on this approach, it was estimated that $39.9 \%$ of California's 2003 jet fuel consumption was for international flights, 52.7\% was for interstate flights, and 7.4\% was for intrastate flights. These shares were applied to the total jet fuel sold in California according to SEDS (U.S. EIA, 2003a) corrected for shares used for military 
purposes (Stamets, 2005). All estimated consumption of military jet fuel is included in the "domestic air transport” flow in CALEB, but is shown separately in Table 25.

\subsection{Coal}

\subsubsection{Trends}

Only the manufacturing and services end-use sectors consume coal in California. Table 27 shows the values for coal consumption by end-use sector. Total coal consumption increased between 1990 and 2001 from 1,648 kst (38 TBtu) in 1990 to 1,937 kst (46 TBtu) in 2001. During the period, there was a significant drop in coal consumption in the early 1990s.

Table 27. Consumption of coal by end-use sector

\begin{tabular}{|l|r|r|r|r|r|r|r|r|r|r|r|r|}
\hline Thousand Short Tons & $\mathbf{1 9 9 0}$ & $\mathbf{1 9 9 1}$ & $\mathbf{1 9 9 2}$ & $\mathbf{1 9 9 3}$ & $\mathbf{1 9 9 4}$ & $\mathbf{1 9 9 5}$ & $\mathbf{1 9 9 6}$ & $\mathbf{1 9 9 7}$ & $\mathbf{1 9 9 8}$ & $\mathbf{1 9 9 9}$ & $\mathbf{2 0 0 0}$ & $\mathbf{2 0 0 1}$ \\
\hline End-Use Sectors & & & & & & & & & & & & \\
Industry & 1,623 & 1,518 & 1,308 & 731 & 825 & 1,160 & 1,309 & 1,667 & 1,885 & 2,036 & 1,992 & 1,937 \\
Services & 25 & 44 & 0 & 142 & 166 & 133 & 177 & 109 & 115 & 28 & 24 & 0 \\
\hline Total & 1,648 & 1,562 & 1,308 & 873 & 991 & 1,293 & 1,486 & 1,776 & 2,000 & 2,064 & 2,016 & 1,937 \\
\hline & & & & & & & & & & & & \\
\hline Trillion Btu & $\mathbf{1 9 9 0}$ & $\mathbf{1 9 9 1}$ & $\mathbf{1 9 9 2}$ & $\mathbf{1 9 9 3}$ & $\mathbf{1 9 9 4}$ & $\mathbf{1 9 9 5}$ & $\mathbf{1 9 9 6}$ & $\mathbf{1 9 9 7}$ & $\mathbf{1 9 9 8}$ & $\mathbf{1 9 9 9}$ & $\mathbf{2 0 0 0}$ & $\mathbf{2 0 0 1}$ \\
\hline End Use Sectors & & & & & & & & & & & & \\
Industry & 37 & 35 & 30 & 17 & 19 & 27 & 31 & 38 & 43 & 47 & 47 & 46 \\
Services & 1 & 1 & 0 & 3 & 4 & 3 & 4 & 3 & 3 & 1 & 1 & 0 \\
\hline Total & 38 & 36 & 30 & 20 & 23 & 30 & 35 & 41 & 46 & 48 & 48 & 46 \\
\hline
\end{tabular}

\subsubsection{Data Sources and Data Issues}

The primary data source for coal consumption is the EIA's Coal Industry Annual (renamed the Annual Coal Report after 2000) ${ }^{21}$ (U.S. EIA, 1996; U.S. EIA, 2001; U.S. EIA, 2004c). This document provides both the total consumption of coal by sector and the volumes of coal by source state. This is important, because the average quality of bituminous coal from state to state ranges from roughly 16 million Btu/short ton to over 23 million Btu/short ton. A source of supplemental data from the U.S. Geological Survey shows the amount of coal consumed by the cement industry in California, which accounts for most of the industrial sector consumption (van Oss, 2004). ${ }^{22}$ However, there is no publicly available data source to show which other industries consumed the remainder of the coal consumed by the other industrial sub-sectors.

Figures from the Coal Industry Annual were adjusted for energy consumed for electricity generation using data from the EIA's Electric Power Annual 2002 spreadsheets (U.S. EIA, 2003c). This adjustment was done for two reasons. First, as with the SEDS data used for other fuels, the Coal Industry Annual only reported electricity generation by utility-owned plants. Thus, coal consumed by CHP plants and IPPs appears in the "Other Industrial Plants" or "Residential and Commercial Sector" categories, whereas the Electric Power Annual figures

\footnotetext{
${ }^{21}$ This data series goes back to 1985 .

${ }^{22}$ The supplemental data from the U.S. Geological Survey on coal consumption in the cement industry fall in the $65 \%$ to $80 \%$ range of total industry sector consumption. However, for some years the figure exceeds $100 \%$ of the CALEB industry total, mostly because the supplemental data include the quantities of coal that may have also been used for CHP, which have been deducted from the CALEB industrial sector figures.
} 
disaggregate the fuel consumed by IPPs and CHP plants. Second, the Coal Industry Annual reports show a significant drop in coal consumption from 1998 to 2000, a drop that corresponds quite closely to the Electric Power Annual 2002 figures for coal used for power generation. Indeed, the Annual Coal Report 2001 provides a much different figure for total state 2000 coal consumption (2,954 kst) than the Coal Industry Annual 2000 (2,015 kst). The difference is entirely in what the Annual Coal Report 2001 refers to as consumption for "electric power" as opposed to the Coal Industry Annual category "electric utility plants." Therefore, the Electric Power Annual 2002 figures are subtracted from the Coal Industry Annual “Other Industrial Plants" figures for the years 1990 to 1997, are used to supplement the Coal Industry Annual data from 1998 to 2000, and are used in place of the Annual Coal Report "electric power" figures for 2001 and 2002.

\subsection{Electricity}

\subsubsection{Trends}

Table 28 shows a collapsed version of the full data table used for the CALEB electricity balances. Overall, electricity consumption grew 14\% from the 1990-1992 period to the 19992001 period (multiyear averages are used for comparison to mitigate the impact of year-toyear fluctuations.) This growth was driven mostly by the services and residential sectors, which both experienced growth of $14 \%$ over the same period.

Table 28. Electricity consumption by end-use sector

\begin{tabular}{|l|r|r|r|r|r|r|r|r|r|r|r|r|}
\hline Terawatt-hours & $\mathbf{1 9 9 0}$ & $\mathbf{1 9 9 1}$ & $\mathbf{1 9 9 2}$ & $\mathbf{1 9 9 3}$ & $\mathbf{1 9 9 4}$ & $\mathbf{1 9 9 5}$ & $\mathbf{1 9 9 6}$ & $\mathbf{1 9 9 7}$ & $\mathbf{1 9 9 8}$ & $\mathbf{1 9 9 9}$ & $\mathbf{2 0 0 0}$ & $\mathbf{2 0 0 1}$ \\
\hline End Use Sectors & & & & & & & & & & & & \\
Agriculture & 7 & 7 & 7 & 6 & 6 & 9 & 6 & 7 & 6 & 7 & 6 & 7 \\
Mining & 1 & 1 & 1 & 1 & 1 & 1 & 2 & 1 & 1 & 1 & 1 & 1 \\
Manufacturing & 39 & 38 & 38 & 37 & 37 & 38 & 39 & 40 & 40 & 40 & 40 & 38 \\
Transport & 2 & 2 & 2 & 2 & 2 & 2 & 2 & 2 & 3 & 2 & 2 & 2 \\
Services & 91 & 87 & 89 & 91 & 92 & 88 & 96 & 99 & 96 & 104 & 110 & 106 \\
Residential & 68 & 67 & 69 & 68 & 70 & 70 & 72 & 74 & 75 & 77 & 81 & 76 \\
Non-specified & 3 & 3 & 4 & 5 & 3 & 4 & 6 & 6 & 5 & 10 & 13 & 12 \\
\hline Total & 210 & 204 & 209 & 211 & 211 & 212 & 223 & 230 & 227 & 240 & 253 & 242 \\
\hline & & & & & & & & & & & & \\
\hline Trillion Btu & $\mathbf{1 9 9 0}$ & $\mathbf{1 9 9 1}$ & $\mathbf{1 9 9 2}$ & $\mathbf{1 9 9 3}$ & $\mathbf{1 9 9 4}$ & $\mathbf{1 9 9 5}$ & $\mathbf{1 9 9 6}$ & $\mathbf{1 9 9 7}$ & $\mathbf{1 9 9 8}$ & $\mathbf{1 9 9 9}$ & $\mathbf{2 0 0 0}$ & $\mathbf{2 0 0 1}$ \\
\hline End Use Sectors & & & & & & & & & & & & \\
Agriculture & 25 & 22 & 24 & 22 & 21 & 32 & 21 & 22 & 20 & 22 & 22 & 23 \\
Mining & 3 & 3 & 3 & 3 & 3 & 3 & 5 & 4 & 3 & 3 & 3 & 3 \\
Manufacturing & 132 & 129 & 128 & 126 & 126 & 130 & 132 & 138 & 138 & 136 & 136 & 131 \\
Transport & 6 & 6 & 7 & 6 & 6 & 7 & 7 & 8 & 9 & 7 & 8 & 8 \\
Services & 309 & 296 & 303 & 311 & 314 & 300 & 327 & 339 & 328 & 355 & 375 & 363 \\
Residential & 231 & 229 & 236 & 234 & 238 & 238 & 246 & 251 & 257 & 261 & 275 & 260 \\
Non-specified & 12 & 9 & 13 & 16 & 12 & 14 & 21 & 21 & 19 & 35 & 45 & 39 \\
\hline Total & 717 & 694 & 714 & 718 & 720 & 724 & 760 & 784 & 773 & 819 & 863 & 826 \\
\hline
\end{tabular}

\subsubsection{Data Sources and Data Issues}

Primary data for electricity consumption are taken from an Energy Commission data series with the same structure as the natural gas data (CEC, 2004a). As with the natural gas data, these are reported directly by the utilities and are grouped into 72 different categories. Because the sales data are reported directly by the distributing utilities, they are considered reliable. 


\section{Total Consumption and Statistical Differences}

CALEB can display a "total consumption" flow, which for each fuel is the sum of all end-use consumption of energy, use for transformation, own use of energy in the energy sector, transformation losses, and distribution losses. ${ }^{23}$ In theory, these totals should match the supply totals, but because supply, transformation, and end use data are collected and reported separately, the totals rarely balance precisely. Thus, statistical difference refers to the difference between total supply of any given fuel and the total consumption of that fuel for transformative and end-use consumption. This expresses the unresolved discrepancies between the supply, transformation, and end use consumption figures.

Table 29 shows the statistical differences by fuel and the total statistical difference and total consumption. This table highlights the need for more complete refinery and petroleum product data for years prior to 1995 in order to complete CALEB back to 1990. For the years with more complete data, the statistical differences are comparable to those found for many countries in the IEA data (IEA, 2003a; IEA, 2003b). Improved accounting of petroleum products and NGLs would help to narrow those differences further.

Table 29. Statistical differences by energy source in trillion Btu

\begin{tabular}{|l|r|r|r|r|r|r|r|r|r|r|r|r|}
\hline Product & $\mathbf{1 9 9 0}$ & $\mathbf{1 9 9 1}$ & $\mathbf{1 9 9 2}$ & $\mathbf{1 9 9 3}$ & $\mathbf{1 9 9 4}$ & $\mathbf{1 9 9 5}$ & $\mathbf{1 9 9 6}$ & $\mathbf{1 9 9 7}$ & $\mathbf{1 9 9 8}$ & $\mathbf{1 9 9 9}$ & $\mathbf{2 0 0 0}$ & $\mathbf{2 0 0 1}$ \\
\hline Nat Gas & -84 & -112 & -17 & -142 & -158 & -156 & 43 & 18 & 116 & 214 & 225 & 4 \\
\hline NGL & -38 & -36 & -39 & -38 & -36 & -2 & -6 & -1 & 0 & -3 & -6 & -5 \\
\hline Additives \& Ethanol & 0 & 0 & 0 & 0 & 0 & 0 & 56 & 40 & 29 & 27 & 21 & 16 \\
\hline Crude & -98 & -76 & -122 & -14 & -179 & -223 & -313 & -164 & -136 & -151 & -17 & 71 \\
\hline Still Gas & 247 & 246 & 238 & 295 & 298 & -35 & -19 & -20 & -19 & -26 & -42 & -27 \\
LPG & 82 & 78 & 87 & 70 & 78 & 66 & -19 & -22 & -12 & -1 & -18 & -3 \\
Motor Gas & 1,606 & 1,568 & 1,657 & 1,621 & 1,615 & 23 & -14 & -23 & -22 & -14 & -61 & -243 \\
Aviation Gas & 6 & 6 & 5 & 4 & 4 & -5 & -4 & -4 & -4 & 1 & -1 & -2 \\
Jet Fuel & 538 & 511 & 492 & 506 & 560 & 0 & 0 & 0 & 0 & 0 & 0 & 0 \\
Kerosene & 2 & 1 & 1 & 1 & 1 & -1 & -4 & -3 & -2 & -1 & -1 & 0 \\
Dist Fuel & 463 & 440 & 415 & 392 & 440 & -132 & 0 & 0 & 0 & 0 & 0 & 0 \\
Res Fuel & 339 & 281 & 198 & 191 & 229 & 3 & 0 & 0 & 0 & 0 & 0 & 0 \\
Pet Coke & 67 & 74 & 77 & 81 & 83 & 0 & 0 & 0 & 0 & 0 & 0 & 0 \\
Lubricants & 30 & 27 & 28 & 28 & 30 & -28 & -21 & -23 & -13 & -24 & -22 & -24 \\
Asphalt & 99 & 95 & 90 & 83 & 81 & 8 & 12 & 2 & 21 & 39 & 25 & 35 \\
Waxes & 3 & 4 & 4 & 5 & 5 & 0 & 0 & -1 & 0 & -2 & -2 & 3 \\
Special Naphthas & 13 & 10 & 12 & 12 & 10 & 5 & 4 & 2 & 2 & 9 & 3 & 6 \\
Petrochem feedstocks & 26 & 17 & 18 & 18 & 18 & -12 & -14 & -6 & -7 & -7 & -4 & -7 \\
Other Petro Prods & 3 & 2 & 1 & 1 & 2 & -9 & -10 & -11 & -12 & -12 & -14 & -14 \\
\hline Tot Petro Products & 3,524 & 3,360 & 3,323 & 3,308 & 3,454 & -117 & -89 & -109 & -68 & -38 & -137 & -276 \\
\hline Petro Prods used for Elec & 66 & 37 & 38 & 56 & 59 & 46 & 60 & 47 & 54 & 46 & 50 & 45 \\
\hline Coal & 2 & 1 & -1 & -4 & -13 & -5 & 9 & 0 & -40 & -52 & -65 & -118 \\
\hline Electricity & -35 & -26 & -18 & -2 & -46 & -41 & 3 & 23 & -57 & -12 & 17 & 27 \\
\hline Total Stat Difference & 3,337 & 3,148 & 3,164 & 3,164 & 3,081 & -498 & -237 & -146 & -102 & 31 & 88 & -236 \\
\hline Total Consumption & 11,669 & 11,376 & 11,395 & 11,349 & 11,453 & 10,930 & 11,366 & 11,615 & 11,939 & 11,937 & 11,974 & 12,009 \\
\hline Stat Diff as \% Tot Cons & $29 \%$ & $28 \%$ & $28 \%$ & $28 \%$ & $27 \%$ & $-5 \%$ & $-2 \%$ & $-1 \%$ & $-1 \%$ & $0 \%$ & $1 \%$ & $-2 \%$ \\
\hline
\end{tabular}

${ }^{23}$ Note that Total Consumption only includes the net losses (or gains) from energy transformation in order to avoid double counting of the inputs and outputs. 


\section{Carbon Dioxide Emissions from Fuel Consumption}

\subsection{Introduction}

Carbon dioxide is the principal GHG emitted as a result of energy use. As fossil fuel is combusted, $\mathrm{CO}_{2}$ is emitted as a result of oxidation of the carbon in the fuel. Once an energy balance has been constructed, it is possible to calculate the $\mathrm{CO}_{2}$ emissions resulting from energy consumption. CALEB has been designed to calculate $\mathrm{CO}_{2}$ emissions following the IPCC methodology (IPCC, 1996). Table 30 shows $\mathrm{CO}_{2}$ resulting from fuel combustion in California, calculated with CALEB. The reference approach uses supply data to estimate total emissions. This approach assumes that all fuel reported as "supplied to the economy" is combusted (adjusting for known non-energy uses). The sectoral approach uses a bottom-up method for estimating emissions using disaggregated end-use consumption data. These two approaches are described in more detail in Section 8.2.2.

Table 30. 2000 Carbon dioxide emissions from fuel combustion in California, million metric tons $(\mathrm{Mt}) \mathrm{CO}_{2}$

\begin{tabular}{|lrrrr|}
\hline & Nat Gas & Petroleum & Coal & Total \\
\hline Reference Approach & 118.4 & 217.4 & 12.8 & 348.5 \\
\hline difference & 11.9 & 0.1 & -6.1 & 5.9 \\
\hline Sectoral Approach & 130.2 & 217.5 & 6.7 & 354.4 \\
\hline Electric Sector & 44.3 & 2.8 & 1.9 & 49.0 \\
CHP, Electric Power & 8.0 & 1.8 & 1.9 & 11.7 \\
Electric Generators, Utilities & 6.8 & 1.0 & 0.0 & 7.9 \\
Electric Generators, IPP & 29.4 & 0.0 & 0.0 & 29.4 \\
Energy Sector & 20.6 & 23.5 & 0.0 & 44.0 \\
Oil Refineries' Own Use & 5.6 & 23.4 & 0.0 & 28.9 \\
Oil and Gas Extraction & 15.0 & 0.1 & 0.0 & 15.1 \\
End Use Sectors & 63.5 & 193.8 & 4.8 & 262.1 \\
Agriculture & 0.9 & 4.4 & 0.0 & 5.3 \\
Mining & 0.3 & 0.0 & 0.0 & 0.3 \\
Manufacturing Sector & 16.3 & 7.0 & 4.7 & 28.1 \\
of which: Feedstock use in petchem. ind. & 0.06 & 0.46 & 0.00 & 0.51 \\
of which: CHP elec generation & 4.73 & 0.14 & 0.32 & 5.19 \\
Transport Sector & 0.7 & 179.5 & 0.0 & 180.2 \\
Services & 16.5 & 2.2 & 0.1 & 18.8 \\
of which: CHP elec generation & 0.71 & 0.72 & 0.00 & 1.43 \\
Residential & 27.9 & 1.7 & 0.0 & 29.6 \\
Non-specified (Other Sector) & 0.8 & 0.1 & 0.0 & 0.9 \\
Non-Energy Use & 0.0 & 1.8 & 0.0 & 1.8 \\
\hline
\end{tabular}

Three energy commodities consumed in the economy produce $\mathrm{CO}_{2}$ emissions: (1) coal, (2) petroleum products, and (3) natural gas. Figure 5 shows the relative importance of $\mathrm{CO}_{2}$ emissions by product and sector. In California, the transport sector is by far the main source of $\mathrm{CO}_{2}$ emissions resulting from fuel combustion, followed by the electric sector. However, it is worth noting that $\mathrm{CO}_{2}$ emissions related to electricity imports (27\% of supply) are not accounted for in the inventory. 


\section{Figure 5. $\mathrm{CO}_{2}$ Emissions fuel combustion in California by fuel and sector in 2000, $\mathrm{Mt} \mathrm{CO}_{2}$}

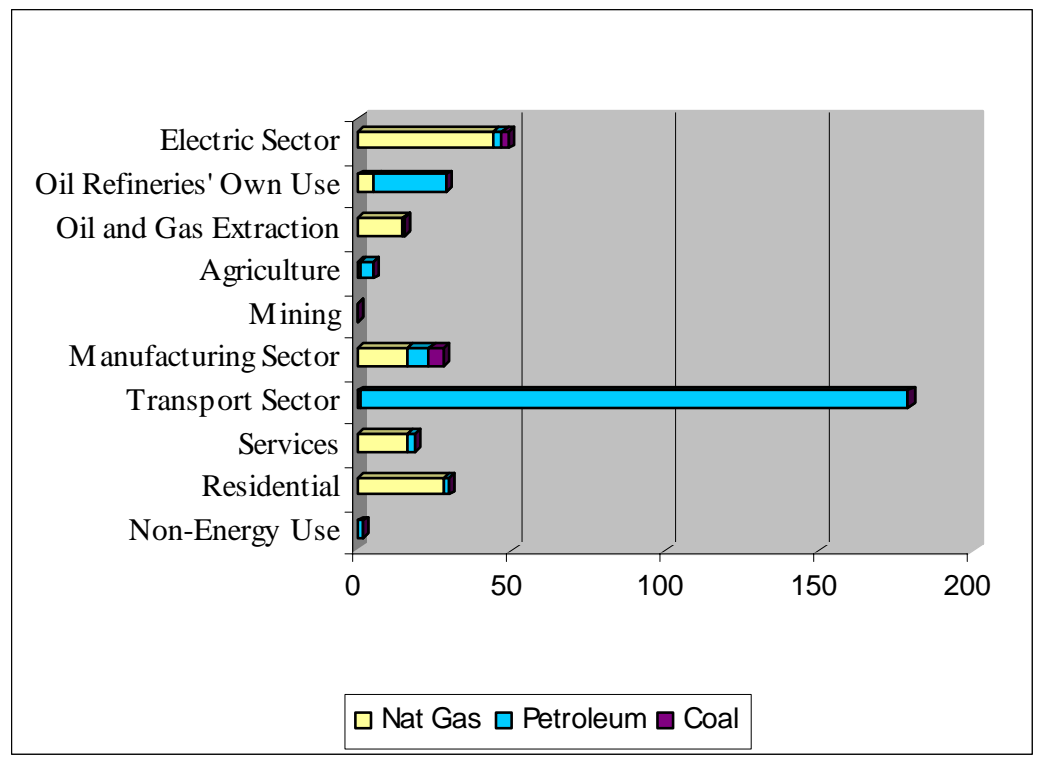

CALEB also offers the possibility of examining sectoral emissions in greater detail. For example, Table 31 shows $\mathrm{CO}_{2}$ emissions from the transport sector at a more disaggregate level.

Table 31. Detailed $\mathrm{CO}_{2}$ emissions in the transport sector in 2000, $\mathrm{Mt}$ of $\mathrm{CO}_{2}$

\begin{tabular}{|c|r|r|r|r|}
\hline End-Use & Natural Gas & Oil Products & Coal & Total \\
\hline Transport Sector & $\mathbf{0 . 7 0}$ & $\mathbf{1 7 9 . 5 1}$ & $\mathbf{0 . 0 0}$ & $\mathbf{1 8 0 . 2 1}$ \\
\hline Railroad transport & 0.01 & 3.00 & 0.00 & 3.01 \\
Road Transport & 0.08 & 148.44 & 0.00 & 148.51 \\
Freight & 0.01 & 0.00 & 0.00 & 0.01 \\
Passenger & 0.06 & 0.00 & 0.00 & 0.06 \\
Private Automobile & 0.06 & 0.00 & 0.00 & 0.06 \\
Taxis and Buses & 0.03 & 0.00 & 0.00 & 0.03 \\
Non-specified (Local Transit) & 0.04 & 0.00 & 0.00 & 0.04 \\
Domestic Water Transportation & 0.00 & 1.61 & 0.00 & 1.61 \\
Domestic Air Transportation & 0.04 & 25.77 & 0.00 & 25.77 \\
Pipelines & 0.57 & 0.00 & 0.00 & 0.57 \\
Pipeline Natural Gas & 0.50 & 0.00 & 0.00 & 0.50 \\
Pipelines, Except Natural Gas & 0.07 & 0.00 & 0.00 & 0.07 \\
Non-specified (Transport) & 0.00 & 0.69 & 0.00 & 0.69 \\
\hline \multicolumn{3}{|c|}{} \\
\hline International Transport* & $\mathbf{0 . 0 0}$ & $\mathbf{3 3 . 3 2}$ & $\mathbf{0 . 0 0}$ & $\mathbf{3 3 . 3 2}$ \\
\hline Maritime Bunker & 0.00 & 17.85 & 0.00 & 17.85 \\
Aviation Bunker & 0.00 & 15.47 & 0.00 & 15.47 \\
\hline
\end{tabular}

$* \mathrm{CO}_{2}$ emissions for International transport from California are not accounted for in domestic inventory. 


\subsection{Methodology}

\subsubsection{Context}

The estimates of $\mathrm{CO}_{2}$ emissions from fuel combustion calculated in CALEB follow the Revised 1996 IPCC Guidelines for National Greenhouse Gas Inventories (IPCC, 1996). The IPCC Guidelines allow parties under the UNFCCC to estimate and report on national inventories of anthropogenic GHG emissions and removals. Inventories are divided according to six source categories: (1) Energy, (2) Industrial Processes, (3) Solvent and Other Product Use, (4) Land-Use Change and Forestry, (5) Agriculture, and (6)Waste Sectors (see Table 32).

\section{Table 32. IPCC main source categories}

\begin{tabular}{|l|}
\hline 1- Energy \\
1- A- Fuel Combustion Activities \\
1- B- Fugitive Emissions from Fuels \\
2- Industrial Processes \\
3- Solvent and Other Product Use \\
4- Agriculture \\
5- Land-Use Change \& Forestry \\
6- Waste \\
Memo Items: \\
International Aviation Bunkers \\
International Marine Bunkers \\
$\mathrm{CO}_{2}$ Emissions from Biomass \\
\hline
\end{tabular}

The category Energy is itself divided in two sub-categories. The first subcategory refers to GHG emissions from fuel combustion activities and the second subcategory to fugitive emissions from fuels. $\mathrm{CO}_{2}$ emissions estimated in CALEB are related to the first subcategory: $\mathrm{CO}_{2}$ emissions from Fuel Combustion Activities. This subcategory comprises the most significant contributor to GHG emissions. For example, in 2002, emissions from fuel combustion in the United States accounted for $85 \%$ of total emissions (U.S. EPA, 2004b). Fugitive emissions from fuels refer to intentional or unintentional releases of gases occurring during the production, processing, transport, storage, or use of fuels (e.g., methane emissions from coal mining). This sub-category also includes emissions from combustion in cases where the combustion does not support a productive activity. Data in CALEB on natural gas flared can be used to calculate that portion of fugitive $\mathrm{CO}_{2}$ emissions. Data on natural gas losses and other fugitive emissions are not included. CALEB also calculates two of the IPCC memo items: ${ }^{24}$ international aviation bunkers and international marine bunkers.

\footnotetext{
${ }^{24}$ Memo items in national inventories are sources of GHG emissions that the IPCC suggests be included in the inventories submitted, even though these emissions do not count toward national totals.
} 


\subsubsection{Approaches}

The calculation of $\mathrm{CO}_{2}$ emissions from fuel combustion may be done at two different levels, which are referred to as the reference approach and sectoral approach. The reference approach method focuses on estimating the emissions from the carbon content of fuels supplied to the country. The sectoral approach calculates $\mathrm{CO}_{2}$ emissions at the source level. The IPCC Guidelines recommend calculating total emissions through both methods for verification purposes (IPCC, 1996).

\subsubsection{Reference Approach}

Theoretically, it is possible to obtain an accurate estimate of national $\mathrm{CO}_{2}$ emissions by accounting for the carbon in fuels supplied to the economy. The reference approach estimates $\mathrm{CO}_{2}$ emissions from California's supply of fossil fuels to the economy by identifying the carbon content, subtracting the carbon stored in non-energy use of fuels, and adjusting for unoxidized carbon. This approach provides an upper bound to $\mathrm{CO}_{2}$ emissions inferred from the state supply.

The reference approach rests on a simple assumption: once carbon is brought into a national economy in fuel, it is either saved in some way (e.g., in increases of fuel stocks, stored in products, left unoxidized in ash) or it must be released to the atmosphere. Accounting for carbon is based mainly on the supply of primary fuels and the net quantities of secondary fuels brought into the country. This is shown in CALEB under the heading "domestic supply.” The manufacture of secondary fuels is ignored, because the carbon in these fuels has already been accounted for in the supply of primary fuels from which they are derived. The reference approach requires statistics for production of fuels, imports and exports, as well as changes in their stocks. Estimates of the consumption of fuels used for non-energy purposes are needed to account for sequestered carbon.

\subsubsection{Sectoral Approach}

The reference approach allows a rapid estimation of the $\mathrm{CO}_{2}$ emissions, but it does not provide a breakdown of the $\mathrm{CO}_{2}$ emissions by economic sector. A sectoral breakdown of national $\mathrm{CO}_{2}$ emissions is needed for monitoring and abatement policy discussions.

The CALEB breakdown of energy data is similar to what is requested by the IPCC guidelines, but two modifications are necessary to calculate $\mathrm{CO}_{2}$ emissions:

1. $\mathrm{CO}_{2}$ emissions resulting from self-generation of electricity should be included in the sector (industrial or commercial) where the self-generation occurs, and not in the transformation sector, as is the case in the energy balance.

2. $\mathrm{CO}_{2}$ emissions from international aviation bunkers need to be extracted from the transport sector and accounted apart from the national total in a memo item.

\subsubsection{Difference between the two approaches}

The reference approach and sectoral approach should, in theory, yield similar results. However, due to the decentralized nature of fuel consumption, statistical differences between 
the two approaches are inevitable. The differences inherent in the energy data account for most of the discrepancy in estimated emissions between the two approaches. Other factors affect the final estimates. For example, different emission factors for each of the petroleum products consumed are used in the sectoral approach; whereas, only the factor for crude oil is used in the reference approach.

\subsection{Conversion Factors}

The conversion of fuel combustion to $\mathrm{CO}_{2}$ emissions requires three types of factors: (1) $\mathrm{CO}_{2}$ emission factors, (2) storage factors, and (3) oxidation factors (IPCC, 1996). Table 33 lists the conversion factors used in CALEB.

Table 33. Carbon content factors, storage factors and fraction of oxidation

\begin{tabular}{|lccc|}
\hline Unit & $\begin{array}{c}\text { Carbon Coefficient } \\
\mathrm{kgC/MMBtu}\end{array}$ & $\begin{array}{c}\text { Storage Factor } \\
\%\end{array}$ & $\begin{array}{c}\text { Fraction Oxidized } \\
\%\end{array}$ \\
\hline Natural Gas & 14.47 & 91 & 99.5 \\
Still Gas & 17.51 & - & 99.5 \\
LPG & $16.98^{*}$ & 91 & 99 \\
Motor Gas & $19.34 *$ & - & 99 \\
Aviation Gas & 18.87 & - & 99 \\
Jet Fuel & $19.33 *$ & - & 99 \\
Kerosene & 19.73 & - & 99 \\
Distillate Fuel & 19.96 & - & 99 \\
Residual Fuel & 21.50 & - & 99 \\
Pet Coke & 27.85 & - & 99 \\
Lubricants & 20.23 & 50 & 99 \\
Asphalt & 20.64 & 100 & 99 \\
Waxes & 19.81 & 100 & 99 \\
Special Naphtha & 19.86 & 0 & 99 \\
Petrochemical feedstocks & $19.87 *$ & $51 *$ & 99 \\
Other Petro Prods & $20.23 *$ & 10 & 99 \\
NGL & 18.24 & 80 & 99.5 \\
Coal & 25.76 & - & 99 \\
Crude Oil & $20.23 *$ & - & 99 \\
\hline
\end{tabular}

Sources: U.S. EPA, 1004b; U.S. EPA, 2005.

* varies annually (factors presented are for 2000)

Note: The storage factors only apply to non energy use.

\subsubsection{Emission Factors}

Carbon dioxide emission factors convert the fuel consumed into the maximum amount of $\mathrm{CO}_{2}$ that can be released in the atmosphere during combustion. Hence, the carbon emissions factor of a particular fossil fuel represents the maximum potential emissions to the atmosphere if all carbon in the fuel is oxidized during combustion. When fuels are burned, most carbon is emitted as carbon immediately during the combustion process. Some carbon is released as carbon monoxide (CO), methane $\left(\mathrm{CH}_{4}\right)$, or non-methane hydrocarbons, which oxidize to carbon in the atmosphere within a period from a few days to 10-11 years. The other carboncontaining gases are also estimated and reported separately. The IPCC methodology accounts for all of the carbon from these emissions in the total for carbon emissions. By reporting 
emissions in this fashion, state estimates of carbon will reflect total loadings of carbon to the atmosphere. That is, all carbon emitted to the atmosphere (except for that emitted in the form of methane) is reported as carbon emissions, even though a very small portion of the carbon will be emitted as these other gases.

The first column in Table 33 shows the carbon factors that have been used in the calculation of carbon emissions from fuel combustion in CALEB. All of these factors were taken from U.S. EPA (2005) except for the energy commodity "additives" and "petrochemical feedstocks." For the former, this study used the same emissions factor as crude oil. Petrochemical feedstocks are composed of two products: naphtha and other oils, which have different emission factors. The production of each of these products is available from the annual Energy Commission reports on refinery operations (CEC, 2005). The research team used the share of each product to calculate an average emission factor.

\subsubsection{Storage Factors}

Some of the fuel supplied to an economy is used as raw material (or feedstock) for manufacture of products such as plastics, fertilizer, or as a non-energy use (e.g., bitumen for road construction, and lubricants). In some cases, the carbon from the fuels is oxidized quickly to carbon. In other cases the carbon is stored (or sequestered) in the product, sometimes for as long as centuries. The amounts stored for long periods are called stored carbon and should be deducted from the carbon emissions calculation. Estimation of stored carbon requires data on fuel used as feedstock and/or quantities of non-energy fuel products. These uses are discussed in more detail in Section 8.5.

The stored factor for natural gas and LPG comes from the inventory of California greenhouse gases and sinks (CEC, 2002a). The two types of petrochemical feedstocks - naphtha and other oil-have different storage factors. The production of each of these products is available in the annual Energy Commission refinery operations report (CEC, 2005). This study used the share of each of these products to calculate an average emission factor.

\subsubsection{Oxidation Factors}

When energy is consumed not all of the carbon in the fuel oxidizes to carbon. Incomplete oxidation occurs due to inefficiencies in the combustion process that leave some of the carbon unburned or partly oxidized as soot or ash. Therefore, an oxidation factor is used to account for the fraction of the potential carbon emissions remaining after combustion. This study used the EPA default factors of 0.99 for solid and liquid fuel and 0.995 for gaseous fuels (U.S. EPA, 2005).

\subsection{Specific Adjustments}

\subsubsection{Bunker Fuels}

The IPCC methodology subtracts the quantities delivered to and consumed by ships or aircraft for international transport from the fuel supplied to the country. In this manner, the carbon emissions arising from the use of international bunkers are not included in the national total. For California, this study has considered interstate travels as domestic. Therefore, the amount of $\mathrm{CO}_{2}$ emissions related to jet fuel consumed for intrastate and interstate travel are shown in 
the California inventory. Although not part of the national inventory, the IPCC guidelines encourage displaying international aviation and marine bunkers emissions in a separate table.

\subsubsection{Biomass Fuels}

Biomass fuels are included in the national energy and emissions accounts for completeness. However, these emissions should not be included in the calculation of national $\mathrm{CO}_{2}$ emissions from fuel combustion since ethanol is considered carbon neutral. ${ }^{25}$ For this reason, the ethanol blended with motor gasoline is subtracted before calculating carbon emissions emitted from motor gasoline consumption.

\subsubsection{CHP Industrial and Commercial Sectors}

Unlike the energy consumption data from the balance, the $\mathrm{CO}_{2}$ emissions produced by the consumption of fossil fuel in CHP plants from the industrial or commercial sector are accounted for in those sectors, and not in the electric power sector. This difference can be explained by the fact that an important purpose of a balance is to show transformation of primary energy to secondary energy, which is grouped in the transformation sector; whereas, the purpose of a carbon inventory is to show where the emissions occur.

\subsection{Non-Energy Use}

A significant portion of fossil fuel is used for non-energy applications. Non-energy uses include products that are used as feedstock in industry or energy products that have no energy use like asphalt and road oil used for road construction. This project assumed non-energy products such as asphalt to be consumed entirely for non-energy purposes. ${ }^{26}$ Feedstocks in industry consisting essentially of NGL, LPG, and natural gas are more difficult to assess. Table 34 summarizes our estimates for non-energy use of fuel for California for 2000.

Table 34. Non-energy use of fuel in 2000 (TBtu)

\begin{tabular}{|l|c|c|c|c|c|c|c|c|}
\hline & $\begin{array}{l}\text { Natural } \\
\text { Gas }\end{array}$ & LPG & Lubricants & Asphalt & Waxes & $\begin{array}{l}\text { Special } \\
\text { Naphtha }\end{array}$ & $\begin{array}{l}\text { Petchem. } \\
\text { feedstocks }\end{array}$ & Other \\
\hline Petchem. Industry & $\mathbf{1 2}$ & $\mathbf{1 3}$ & $\mathbf{0}$ & $\mathbf{0}$ & $\mathbf{0}$ & $\mathbf{0}$ & $\mathbf{1 1}$ & $\mathbf{0}$ \\
\hline Non-Energy Use & $\mathbf{0}$ & $\mathbf{0}$ & $\mathbf{3 1}$ & $\mathbf{1 2 5}$ & $\mathbf{4}$ & $\mathbf{9}$ & $\mathbf{0}$ & $\mathbf{1}$ \\
\hline Industry & 0 & 0 & 13 & 125 & 4 & 9 & 0 & 1 \\
Transport & 0 & 0 & 18 & 0 & 0 & 0 & 0 & 0 \\
\hline
\end{tabular}

\subsubsection{Industry Feedstocks}

The industrial sector uses some energy products for their chemical properties, rather than for their energy content. This use of energy products has a different accounting methodology in terms of carbon emissions. The major industrial users of fossil fuel feedstocks in the United States are the primary metal and the chemical industries. In the primary metal industry, fossil fuels are used for conversion in carbon anodes for aluminum smelting and in graphite electrodes for steel production. The chemical industry uses fossil-fuel feedstocks for the

\footnotetext{
${ }^{25}$ The carbon released when ethanol is combusted is the same quantity as the carbon that has been removed during the growth of the biomass used to produce ethanol.

${ }^{26}$ Although these products are assumed to be used entirely for non-energy uses, this does not imply that they are never oxidized. CALEB uses the assumptions described in the California inventory (CEC, 2002a).
} 
production of petrochemical products such as ethylene and methanol and in the production of nitrogenous fertilizers.

\subsubsection{Natural Gas Liquids}

Natural gas liquids are composed of ethane, propane, butane, and pentane plus-which are recovered from natural gas in separation facilities or gas processing plants. Parts of the production are transferred to the refineries, and the rest is consumed directly. Data on direct consumption for the State of California comes from data on pentane plus and ethane from the American Petroleum Institute (API, 2002). The API reports no consumption in the petrochemical industry.

\subsubsection{Liquefied Petroleum Gases}

Liquefied petroleum gases consist mainly of propane and butane or a combination of the two. They can be used as feedstocks by the petrochemical industry. The API provides data on sales to this sector for their use as raw materials (API, 2002).

\subsubsection{Special Naphtha}

Special naphtha is the naphtha that is intended for use as solvent. Data on consumption were taken from SEDS (U.S. EIA, 2004a). SEDS allocates the total U.S. consumption at the state level according to the value added of their organic chemical industries. For this study, this product is considered to be entirely consumed for non-energy purposes.

\subsubsection{Petrochemical feedstocks}

The petrochemical feedstocks group includes naphtha and other oils. Data on consumption are taken from SEDS. Data on consumption were taken from SEDS (U.S. EIA, 2004a). SEDS allocates the total U.S. consumption of petrochemical feedstocks to the states, according to each state's share of the total national value added from the organic chemical industry. For this study, this product is considered to be entirely consumed for non-energy purposes.

\subsubsection{Petroleum Coke}

Petroleum coke is used in the energy sector as catalyst coke in refineries in a process for increasing the yield of gasoline from crude oil (i.e., catalytic cracking). This process involves the burning of the petroleum coke and is considered as energy use. Data on refinery consumption are given in the Energy Commission’s M13 Survey data (Helmowski, 2004). In the industrial sector, petroleum coke can be used as an energy product in the cement industry or as non-energy product for conversion in carbon anode for aluminum smelting and in graphite electrodes for steel production. In California, some consumption of petroleum coke occurs in the cement industry, and the data come from the United States Geological Survey (USGS) (van Oss, 2004). The research team assumed that no consumption of petroleum coke occurred for aluminum or steel production, because no primary steel or aluminum is produced in California. 


\subsubsection{Non-Energy Products}

\subsubsection{Lubricants}

Lubricants include all grades of lubricating oils from spindle oil to cylinder oil and those used in greases. SEDS provides state shares of a 1977 survey published by the Bureau of the Census called Sales of Lubricating and Industrial Oils and Greases (U.S. EIA, 2004d). All this consumption is assumed to be non-energy use.

\subsubsection{Waxes}

Waxes are defined as a solid or semi-solid material derived from petroleum distillates or residues by such treatments as chilling, precipitating with a solvent, or de-oiling. They are mostly used in food packaging. Because petroleum waxes are very cost-effective moisture and gas barriers, food packaging is the largest market for petroleum waxes in the United States, accounting for more than $50 \%$ of petroleum wax consumption. SEDS allocates U.S. data to the states in proportion to the value added in the manufacture of corrugated and solid fiber boxes (U.S. EIA, 2004d).

\subsubsection{Asphalt and Road Oils}

Consumption data for asphalt and road oils for 2002 and 2003 were provided by the Asphalt Institute (2005). Asphalt and road oils are consumed entirely for non-energy purposes.

\subsubsection{Other Petroleum Products}

Other petroleum products include miscellaneous products that are defined by the Energy Commission as all finished products not classified elsewhere (e.g., petrolatum and lube refining byproducts), aromatics and tars, absorption oils, ram-jet fuel, petroleum rocket fuels, synthetic natural gas feedstocks, and specialty oils (CEC2005). The Other Petroleum Products category is divided into two sub-categories: non-fuel use and fuel use. For most of the years, the latter is equal to zero, meaning that all miscellaneous products are used for non-energy purposes. 


\section{Summary and Next Steps}

This report presents the findings from the first stage of the CALEB data project. Overall, the total statistical difference for 2000 was a little over $1 \%$. Unfortunately, this encouragingly low difference in the totals does not apply to all of the individual fuels or all of the years covered by the database. The statistical differences for coal, NGL, and some of the petroleum products remain quite large.

With respect to transformation, Berkeley Lab and Energy Commission staff need to collect and analyze petroleum product data for years before 1995 in order to complete the CALEB flows back to 1990 and from 2001 forward. Moreover, additional effort is needed to improve the petroleum product balance even for 1995 to 2001, due to the complexity of refinery operations and petroleum product flows.

Three aspects of petroleum product consumption need to be further developed to improve the balance. First, detailed subsector-level data are not maintained because of the decentralized nature of petroleum product distribution. Data are only reported at highly aggregated, sectoral levels by sources such as SEDS. However, any attempt to allocate consumption to more detailed subsectors would require significant analysis and would ultimately rest on a number of assumptions. Second, although the research team has devised a method to allocate jet fuel and marine bunker fuels to international transportation, the allocations are currently based on year 2000 shipping and year 2003 aviation records. More work is needed to collect and analyze data for other years. Third, more data are also needed to estimate the use of petroleum products, natural gas, and NGLs for feedstocks.

The electricity sector has presented several analytic hurdles. Data on actual power flows into and out of the state are not publicly available; hence, Energy Commission figures on estimated net imports were used for most years (CEC, 2003a). Berkeley Lab is currently assembling Federal Energy Regulatory Commission (FERC) Form 714 data from California utilities and the California Independent System Operator. The data included in the filings for these forms track electricity exchanges between power control areas. In theory, the exchanges listed between California and out-of-state control areas should yield an accurate figure for total electricity imports and exports. FERC Form 1 and EIA 412 data provide data on specific power purchase transactions (FERC, 2003; U.S. EIA, 2004e), but despite this level of detail, there are two main obstacles to attempting to accurately account for all electricity imports and exports for the State of California with this data. First, California utilities purchase large shares of power from energy marketers and the California Department of Water Resources (DWR), and these organizations do not disclose the sources of the power they sell on either the FERC 1 or EIA 412 forms. Therefore, the power sold by energy marketers and the DWR could come from either in-state or out-of-state plants. Second, from 1998 to 2000, the investor-owned utilities began to purchase power from the California Power Exchange. The sources of power that supplied the Power Exchange are not publicly disclosed.

Simplified assumptions regarding annual transmission and distribution losses were also used and these will need to be improved for subsequent versions of CALEB. A final improvement considered for future updates is the disaggregation of landfill gas and municipal solid waste 
plants, which are reported as one figure in the Renewable Energy Annuals (U.S. EIA, various years). A plant-level examination of eGRID (U.S. EPA, 2004a) would enable a disaggregation of generation from these two sources.

In the future, inclusion of economic activity data (such as population, value added, passengermiles traveled, and service sector floor space) would enable CALEB to produce indicators of energy intensity (energy consumed per unit of activity) for various end-use sectors. With sufficient data, a decomposition of structural and intensity trends driving energy use in California may be possible. ${ }^{27}$

\footnotetext{
${ }^{27}$ For a review of energy indicators and decomposition analysis, see Schipper et al. (2001).
} 


\section{References}

American Petroleum Institute, 2002. “2001 Sales of Natural Gas Liquids and Liquefied Refinery Gases.” Washington, D.C.: American Petroleum Institute.

Asphalt Institute, 2005. “Asphalt Usage Survey for the United States and Canada.” Lexington, Kentucky: Asphalt Institute.

Bemis, G., 2004. Personal communication: gasoline energy content estimates from Gerry Bemis, California Energy Commission

Braithwaite, L., M. DiGiovanna, J. Fore, J. Gopal, M. Marks, L. Marshall, D. Maul, T. Peterson, A. Tanghetti, D. Vidaver, B. Wood. 2003. Natural Gas Market Assessment. Sacramento, Calif.: California Energy Commission. www.energy.ca.gov/reports/2003-0808_100-03-006.PDF.

Brown, R., and J. Koomey. 2003. "Electricity Use in California: Past Trends and Present Usage Patterns,” Energy Policy 31(9): 849-864.

California Air Resources Board (CARB). 2004. Statewide Commercial Harbor Craft Survey: Final Report. Sacramento, Calif.: CARB.

California Board of Equalization (BOE), 2003. State Board of Equalization Annual Report 2001-2002: Statistical Appendix. www.boe.ca.gov/annual/statindex0102.htm.

California Department of Conservation, various years. Annual Report of the State Oil \& Gas Supervisor. Sacramento, Calif. Department of Conservation, Division of Oil, Gas \& Geothermal Resources.

www.consrv.ca.gov/dog/pubs_stats/annual_reports/annual_reports.htm.

California Energy Commission, 1995. 1994 Electricity Report: Appendices. Sacramento, Calif.: California Energy Commission.

California Energy Commission, 2000. California Energy Demand, 2000-2010. Sacramento, Calif.: California Energy Commission, http://www.energy.ca.gov/reports/2000-07-14_20000-002.PDF.

California Energy Commission, 2001. California Power Plants Database. Sacramento, Calif.: California Energy Commission. www.energy.ca.gov/database/POWER_PLANTS.xls.

California Energy Commission, 2002a. Inventory of California Greenhouse Gas Emissions and Sinks: 1990-1999. 600-02-001F and 600-02-001F-ES. Sacramento, Calif.: California Energy Commission. www.energy.ca.gov/reports/600-02-001F/. 
California Energy Commission, 2002b. Gulf Coast to California Pipeline Feasibility Study. P600-02-010DCR. Sacramento, Calif.: California Energy Commission. www.energy.ca.gov/reports/2002-03-11_600-02-010DCR.PDF.

California Energy Commission, 2003a. California Electrical Energy Generation, 1983-2002. Sacramento: California Energy Commission, www.energy.ca.gov/electricity/index.html\#generation.

California Energy Commission, 2003b. Spreadsheet of aggregated data from the EIA 810 "Monthly Refinery Report," collected by the Energy Commission.

California Energy Commission, 2003c. Oil Supply Sources to California Refineries. Sacramento, Calif.: California Cnergy Commission. www.energy.ca.gov/oil/statistics/crude_oil_receipts.html.

California Energy Commission, 2004a. Electricity Consumption by Standard Industrial Classification Code. Sacramento, Calif.: California Energy Commission.

California Energy Commission, 2004b. Natural Gas Consumption by Standard Industrial Classification Code. Sacramento, Calif.: California Energy Commission.

California Energy Commission, 2004c. California Natural Gas Facts and Figures. Sacramento, Calif.: California Commission. www.energy.ca.gov/naturalgas/natural_gas_facts.html.

California Energy Commission, 2004d. California Natural Gas Supply by Source. Sacramento, Calif.: California Energy Commission. www.energy.ca.gov/naturalgas/statistics/gas_supply_by_source.html.

California Energy Commission, 2004e. Oil Supply Sources to California Refineries. Sacramento, Calif:: California $\quad$ Energy www.energy.ca.gov/oil/statistics/crude_oil_receipts.html.

California Energy Commission, 2004f. Foreign Sources of Crude Oil Imports to California 2002. Sacramento, Calif.: California Energy Commission.

www.energy.ca.gov/oil/statistics/2002_foreign_crude_sources.html

California Energy Commission, 2004g. California Refining Industry Operating Reports. Sacramento, Calif.: California Energy Commission. www.energy.ca.gov/oil/refinery_output/

California Energy Commission, 2004h. Natural Gas Consumption for Combined Heat and Power. Sacramento, Calif.: California Energy Commission.

California Energy Commission, 2005. Yearly Input and Output at Refineries, 1995-2003. Sacramento, Calif.: California Commission. www.energy.ca.gov/oil/refinery_output/index.html. 
Distances.com, 2005. World Ports Distance Calculator. www.distances.com/, accessed March 11, 2005.

European Environment Agency (EEA), 2004. EMEP/CORINAIR Emission Inventory Guidebook - 3rd edition September 2004 UPDATE. Copenhagen: EEA. http://reports.eea.eu.int/EMEPCORINAIR4/en.

Federal Energy Regulatory Commission, 2003. Form 1: Electric Utility Annual Report. www.ferc.gov/docs-filing/eforms/form-1/viewer-instruct.asp.

Federal Energy Regulatory Commission, 2005. Form 714: Annual Electric Control and Planning Area Report. www.ferc.gov/docs-filing/eforms/form-714/data.asp.

Freme, 2004. Personal communication with Fred Freme, U.S. Energy Information Administration.

Helmowski, B., 2004. Annual aggregated data from CEC M13 reporting form, via personal communication.

Intergovernmental Panel on Climate Change, 1996. Revised 1996 Guidelines for National Greenhouse Gas Inventories. www.ipcc-nggip.iges.or.jp/public/gl/invs1.htm.

Intergovernmental Panel on Climate Change, 2001. Climate Change 2001: Synthesis Report. Cambridge, UK and New York, New York: Cambridge University Press. Glossary: www.ipcc.ch/pub/syrgloss.pdf.

International Energy Agency, 2003a. Energy Balances of OECD Countries. Paris: IEA.

International Energy Agency, 2003b. Energy Balances of Non-OECD Countries. Paris: IEA.

Journal of Commerce Group, 2004. Port Import Export Reporting Service, www.piers.com/default2.asp.

Kaiper, G., 2003. California Energy Flow - 1999. Livermore, Calif.: Lawrence Livermore National Laboratory. http://eed.llnl.gov/flow/pdf/ucrl18991_99.pdf.

Morris, G., 2002. Biomass Energy Production in California 2002: Update of the California Biomass Database. Golden, Colorado: National Renewable Energy Laboratory http://www.nrel.gov/docs/fy03osti/33111.pdf.

Morris, G., 2004. California Biomass Data, provided via personal communication.

Perez, P., 2002. "Replacing MTBE with Ethanol in California.” Presentation by Pat Perez, California Energy Commission, to the Governors' Ethanol Coalition, San Diego, California, February 27, 2002. 
Port of Long Beach. 2003. 2003 Annual Report: Port Stats. Long Beach, Calif. www.polb.com/pdfs/1_about/2003Annual/Pages30-31.PDF.

Port of Oakland. 2003. Port of Oakland Top 20 Trading Partners By Weight - Exports. Oakland, Calif. www.portofoakland.com/maritime/facts_trade_02.asp.

Schipper, L., and J. E. McMahon, 1995. Energy Efficiency in California: A Historical Analysis. Washington, D.C.: American Council for an Energy-Efficient Economy.

Schipper, L., F. Unander, S. Murtishaw, and M. Ting, 2001. "Indicators of Energy Use and Carbon Emissions: Explaining the Energy Economy Link" in Annual Review of Energy and the Environment vol. 26, R. H. Socolow, D. Anderson, and J. Harte, eds. Palo Alto, Calif.: Annual Reviews.

Stamets, L., 2005. Personal communication: Share of jet fuel sold in California used by the military from Leigh Stamets, California Energy Commission.

United Nations, 1982. Concepts and Methods in Energy Statistics, with Special Reference to Energy Accounts and Balances. New York: United Nations. ST/ESA/STAT/SER.F/29 http://unstats.un.org/unsd/publication/SeriesF/SeriesF_29E.pdf.

United Nations Framework Convention on Climate Change, 2003. Methodological Issues: Emissions Resulting from Fuel Used in International Aviation and Maritime Transportation. FCCC/SBSTA/2003/INF.3 http://unfccc.int/resource/docs/2003/sbsta/inf03.pdf

U.S. Army Corps of Engineers, 2002. Waterborne Commerce of the United States: Calendar Year 2002: Part 4, Waterways and Harbors, Pacific Coast, Alaska, and Hawaii. Alexandria,Virginia: Army Corps of Engineers, Institute of Water Resources. www.iwr.usace.army.mil/ndc/wcsc/pdf/wcuspac02.pdf.

U.S. Bureau of Transportation Statistics (BTS), 2004. Air Carriers : T-100 Segment Data Series. Washington, DC: BTS. www.transtats.bts.gov/.

U.S. Energy Information Administration, various years. Petroleum Supply Annual. Washington, D.C.: EIA.

www.eia.doe.gov/oil_gas/petroleum/data_publications/pet_data_publications.html.

U.S. Energy Information Administration, various years. Natural Gas Annual. Washington, DC: EIA.

www.eia.doe.gov/oil_gas/natural_gas/data_publications/natural_gas_annual/nga.html.

U.S. Energy Information Administration, various years. Renewable Energy Annual. Washington D.C.: EIA (DOE/EIA-0603(99)). 
U.S. Energy Information Administration, various years. Coal Industry Annual. Washington, D.C.: EIA (DOE/EIA-0548).

U.S. Energy Information Administration, 1996. Coal Industry Annual. Washington, D.C.: EIA.

U.S. Energy Information Administration, 2000. Fuel Oil and Kerosene Sales 2000. Washington, D.C.: DOE.

U.S. Energy Information Administration, 2001. Coal Industry Annual 2000, Washington, D.C.: EIA (DOE/EIA-0548).

U.S. Energy Information Administration, 2003a. State Consumption Data. Washington, D.C.: EIA. www.eia.doe.gov/emeu/states/_use_multistate.html.

U.S. Energy Information Administration, 2003b. Electric Power Annual 2002. Washington, D.C.: EIA. www.eia.doe.gov/cneaf/electricity/epa/epa_sum.html.

U.S. Energy Information Administration, 2003c. Annual Coal Report 2001. Washington, D.C.: EIA.

U.S. Energy Information Administration, 2003d. Emissions of Greenhouse Gases in the United States 2002. Washington, D.C.: E IA (DOE/EIA-0573).

www.eia.doe.gov/oiaf/1605/ggrpt/.

U.S. Energy Information Administration, 2003e. Annual Energy Review 2002. Washington, D.C.: EIA. www.eia.doe.gov/emeu/aer/.

U.S. Energy Information Administration, 2004a. Individual State Data: California. Washington, D.C.: EIA. www.eia.doe.gov/emeu/states/main_ca.html.

U.S. Energy Information Administration, 2004b. Crude Oil and Petroleum Product Imports by PADD. Washington, D.C.: EIA.

www.eia.doe.gov/oil_gas/petroleum/info_glance/importexport.html.

U.S. Energy Information Administration, 2004c. Annual Coal Report 2002. Washington, D.C.: EIA. www.eia.doe.gov/cneaf/coal/page/acr/acr_sum.html.

U.S. Energy Information Administration, 2004d. State Energy Data 2001: Technical Notes, Section 4. Petroleum Products.

www.eia.doe.gov/emeu/states/sep_use/notes/use_petrol.pdf.

U.S. Energy Information Administration, 2004e. Form EIA-412 Database: Annual Electric Industry Financial Report. www.eia.doe.gov/cneaf/electricity/page/eia412.html. 
U.S. Energy Information Administration, 2004f. Form EIA-860B Database: Annual Electric Generator Report - Nonutility. www.eia.doe.gov/cneaf/electricity/page/eia860b.html.

U.S. Energy Information Administration, 2004g. Form EIA-906/920 Database: Monthly Utility and Nonutility Power Plant Data.

www.eia.doe.gov/cneaf/electricity/page/eia906_920.html.

U.S. Energy Information Administration, 2005a. Natural Gas Navigator: California Natural Gas Summary. http://tonto.eia.doe.gov/dnav/ng/ng_sum_lsum_dcu_SCA_a.xls.

U.S. Energy Information Administration, 2005b. Natural Gas Navigator: California International and Interstate Movements.

http://tonto.eia.doe.gov/dnav/ng/xls/ng_move_ist_a2dcu_SCA_a.xls.

U.S. Environmental Protection Agency, 2004a. eGRID 2002 Database.

www.epa.gov/cleanenergy/egrid/download.htm.

U.S. Environmental Protection Agency, 2004b. Inventory of U.S. Greenhouse Gas Emissions and Sinks: 1990-2002. http://yosemite.epa.gov/oar/globalwarming.nsf/content/ ResourceCenterPublicationsGHGEmissionsUSEmissionsInventory2004.html.

U.S. Environmental Protection Agency, 2005. Emission Inventory Improvement Program, Technical Report Series, Vol. 8.

www.epa.gov/ttn/chief/eiip/techreport/volume08/index.html.

U.S. Waterborne Commerce Statistics Center (WCSC). 2000a. 2000 Commodity Movements: State to State. U.S. Army Corps of Engineers. New Orleans: WCSC. www.iwr.usace.army.mil/ndc/wcsc/wcsc.htm.

U.S. Waterborne Commerce Statistics Center (WCSC). 2000b. Waterborne Commerce of the United States: Calendar Year 2000. U.S. Army Corps of Engineers. New Orleans: WCSC. www.iwr.usace.army.mil/ndc/wcsc/pdf/wcuspac00.pdf.

van Oss, H. G., 2004. Fuel and Electricity Consumption by California Cement Plants, 19912002, Washington, D.C.: U.S. Geological Survey.

Walzer, D., 2004. Data set from the Fuel Oil and Kerosene Sales reports provided via personal communication from Dan Walzer, U.S. EIA.

Wood, B., 2004. Spreadsheet of California natural gas production, via personal communication from Bill Wood, California Energy Commission. 


\section{Abbreviations and Acronyms}

\begin{tabular}{|c|c|}
\hline $\mathrm{ARB}$ & (California) Air Resources Board \\
\hline bbl & barrel \\
\hline bcf & billion cubic feet \\
\hline $\mathrm{BOE}$ & (California) Board of Equalization \\
\hline Btu & British thermal unit \\
\hline $\mathrm{C}$ & carbon \\
\hline CALEB & California Energy Balances \\
\hline CEC & California Energy Commission \\
\hline CHP & combined heat and power \\
\hline $\mathrm{CO}_{2}$ & carbon dioxide \\
\hline eGRID & Emissions \& Generation Resource Integrated Database \\
\hline EIA & Energy Information Administration \\
\hline FERC & Federal Energy Regulatory Commission \\
\hline GHG & greenhouse gas \\
\hline GWh & gigawatt-hour \\
\hline $\mathrm{HHV}$ & higher heating value \\
\hline ICAO & International Civil Aviation Organization \\
\hline IEA & International Energy Agency \\
\hline IMO & International Maritime Organization \\
\hline IPCC & Intergovernmental Panel on Climate Change \\
\hline IPP & independent power producer \\
\hline kbbl & thousand barrels \\
\hline kst & thousand short tons \\
\hline LHV & lower heating value \\
\hline LPG & liquid petroleum gas \\
\hline MBtu & million Btu \\
\hline MSW & municipal solid waste \\
\hline NAICS & North American Industry Classification System \\
\hline NGL & natural gas liquid \\
\hline PADD & Petroleum Administration for Defense District \\
\hline PIERS & Port Import Export Reporting Service \\
\hline PIIRA & Petroleum Industry Information Reporting Act \\
\hline SEDS & State Energy Data System \\
\hline SI & Système International \\
\hline SIC & Standard Industrial Classification \\
\hline $\mathrm{T} \& \mathrm{D}$ & transmission and distribution \\
\hline TBtu & trillion Btu \\
\hline TEOR & thermally enhanced oil recovery \\
\hline toe & (metric) tons of oil equivalent \\
\hline UNFCCC & United Nations Framework Convention on Climate Che \\
\hline
\end{tabular}

